



DEPARTMENT OF THE INTERIOR

UNITED STATES GEOLOGICAL SURVFY

GEORGE OTIS SMITH, DIRECTOH

WATER-SuppĹy PAPER 239

THE

\section{QUALITY OF THE SURFACE WATERS OF ILLINOIS}

BY

W. D. COLLINS

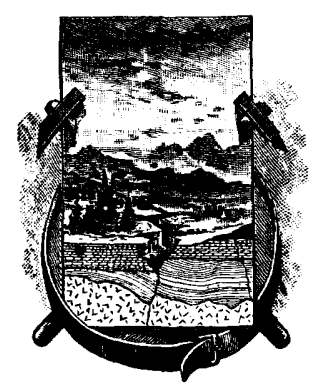

WASHINGTON

GOVERN M N T PRINTING OFFICE

1910 



\section{CONTENTS.}

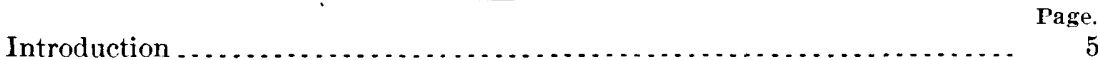

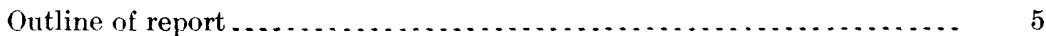

Need of investigation . . . . . .

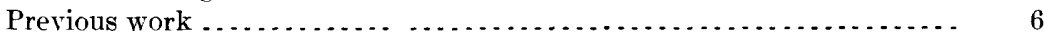

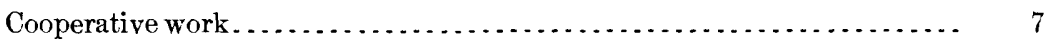

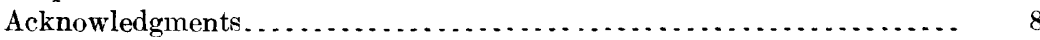

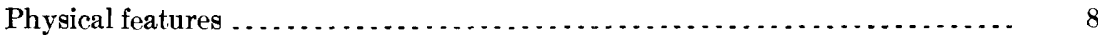

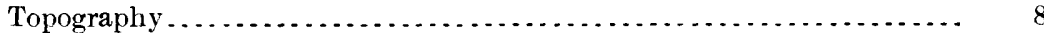

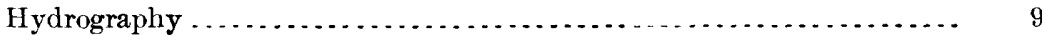

Climate.................................................... 9

Geology ......................................................... 10

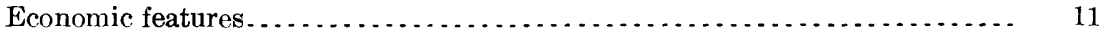

Population .................................................... 11

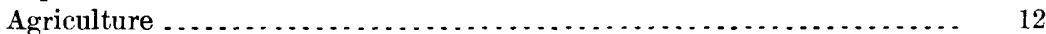

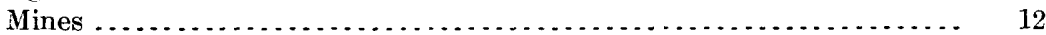

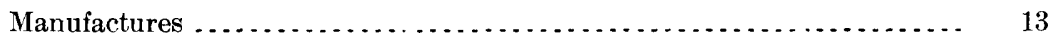

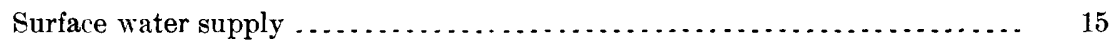

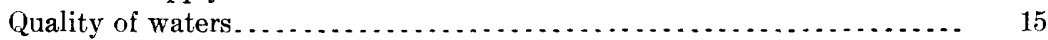

Collection of samples................................... 15

Analytical methods.......................................... 15

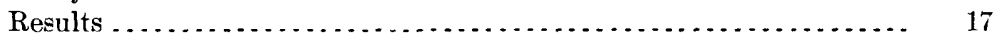

Detailed investigations......................................... 17

Lake Michigan........................................... 17

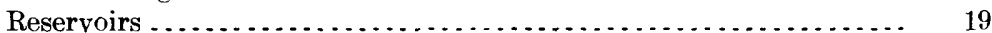

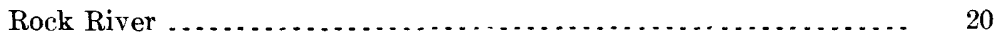

Illinois River drainage basin . . . . . . . . . . . . . . . . . .

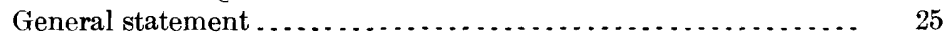

Chicago drainage canal . . . . . . . . . . . . . . . . . . . . . . . 25

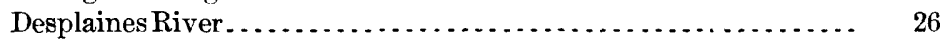

Kankakee River.................................. $\quad 26$

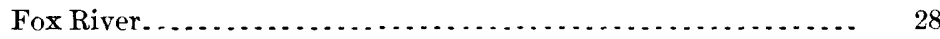

Vermilion River.................................... 30

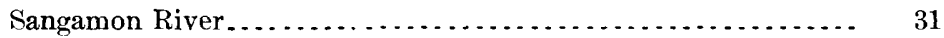

Illinois River......................................... 33

Kaskaskia River....................................... 38

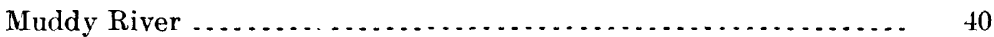

Mississippi River ........................................ 41

Wabash River system................................. 49

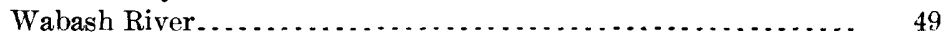

Vermilion River................................... 49

Embarrass River .................................... 50

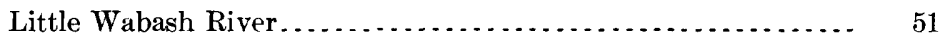

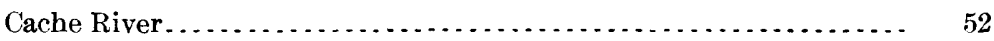

Ohio River............................................... 53 
Surface water supply-Continued. Page.

Municipal supplies...................................... 53

Wells..................................................... 53

Surface supplies ............................................. 54

Untreated waters................................... 54

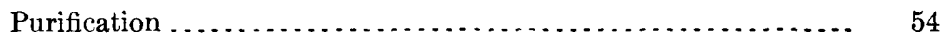

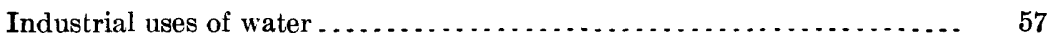

General statement.......................................... 57

Laundry water ............................................ 57

Steam-boiler water............................................ 58

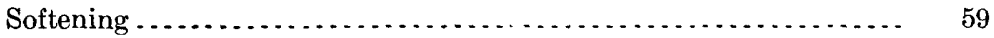

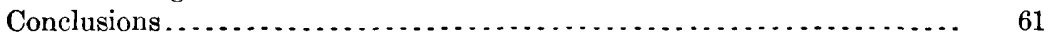

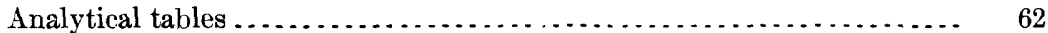

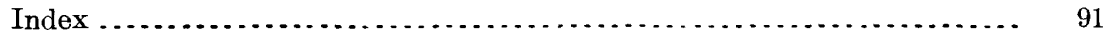

\section{ILLUSTRATIONS.}

Plate I. Map of Illinois showing location of sampling stations..............

Page.

II. Diagrams showing composition of material carried by Illinois waters.

III. Diagrams showing relative amounts of dissolved and suspended material carried by Illinois waters. 


\title{
THE QUALITY OF THE SURFACE WATERS OF ILLINOIS.
}

\author{
By W. D. Collins.
}

\section{INTRODUCTION.}

OUTLINE OF REPORT.

This report furnishes the means of stating with fair accuracy the quality of water which may be found at any point along the larger streams within or bordering the State of Illinois. It also includes some explanation of the variations in the quality of the water at different times and places. The natural and economic features which determine the character of the streams are considered in a general way. The larger drainage divisions are described briefly. A short account of the distribution of population and prin cipal industries of the State shows how these are affected by the streams and how they influence the quality of water in the streams. Methods of collecting and analyzing samples of water are described. The surface waters of the State were represented by samples taken at 27 different points. Each river is discussed in detail with reference to its source, course, discharge, and quality of water. The cities located on it are considered with reference to their use of and their effect on the water. Short chapters on municipal supplies and industrial uses of water save needless repetition in discussing the value of the water of each river. It is shown that the only large supplies of water in the State are surface waters. Nearly all the surface waters are so polluted as to be unfit for domestic use without purification. They usually contain such dissolved mineral matter and so much suspended material as to be unsuitable for many manufacturing purposes, but by proper treatment they may be rendered safe for drinking and suitable for all industrial uses. The proper purification of surface waters is in the greater part of the State the only way to obtain a large supply of satisfactory water. If in some vay the flow of all streams might be regulated and kept more uniform, the increased uniformity in quality of the water would make much easior the problem of proper treatment.

The average amount of water used each day in cities of the United States varies from 50 to 150 gallons per capita. Of this the amount used for drinking is not much over one-half gallon. It is of the 
greatest importance that this one-half gallon shall $k_{e}$ free from the germs of disease, notably typhoid fever, and shall be reasonably clear and reasonably free from taste. This is all thet is required to make this one-half gallon a satisfactory water. For many uses, as sprinkling streets, flushing sewers, etc., almost nothing is required in the way of purity. There is left for consideration a large number of other uses in which the value of the water depends on the amount and kind of mineral matter it contains. For use in laundries, in steam boilers, in textile works, and for the same kind of work at home, the best water is one which is clear, is free from iron, and contains only a moderate amount of other mineral matter.

\section{NEED OF INVESTIGATION.}

In time past the attention of those concerned with the quality of water has been directed very largely to the question of its fitness for drinking, but within the last few years corporations and communities have awakened to a realization of the great waste occasioned by the industrial use of unsuitable waters. The railroads of the country are spending thousands of dollars every year in treating their boilerfeed waters so as to render them less injurious to their boilers, the money thus spent being saved many times over in decreased cost of repairs and increased life of locomotive boilers. Many laundries find it profitable to install expensive apparatus for softening water, rather rather soften it with soap. Water must be purified for use in many woolen mills, breweries, and other establishments, while in some cities the whole city supply is softened.

In planning a waterworks system for home, factory, or municipality, it is not enough to know whether the water is safe for drinking. To determine the best water for all purposes, it is neressary to know the amount and character of the mineral matter it contains. Without such knowledge, no estimate can be made of the cost of purifying the water and making it suitable for drinking and for industrial uses. For most well waters a single analysis is enough to give a very accurate idea of the water which may be found in a given well, but the quality of the water in a stream varies so much that an opinion based on the results of an examination of a single sample of water from a given river would nearly always be very different from an opinion based on the results of a series of analyses, where the samples were taken regularly for some time.

\section{PREVIOUS WORK.}

A large amount of work had been done on the quality of river waters in Illinois before the beginning of this report. In Water-Supply Paper $194^{a}$ M. O. Leighton has given a digest of the testimony

$a$ Pollution of Illinois and Mississippi rivers by Chicago sewage: Water-Supply Paper U. S. Geol. Survey No. $194,1907$. 
in the suit of the State of Missouri against the State of Illinois and the sanitary district of Chicago. As evidence in this case, results were presented from several thousand analyses of samples of water from Illinois River and its tributaries, with many analyses of Missouri and Mississippi water. The analyses made at that time were not analyses of the mineral constituents, but were mainly determinations of the amounts of certain substances present in very small quantities, usually less than 1 per cent of the total material dissolved in the water. These results merely indicated the purity of the water as regards sewage contamination and have little value for determining the value of the water for any use other than for drinking.

The Illinois State Water Survey, organized in 1895, ras made a great many analyses of Illinois waters, but most of them have been for the purpose of determining the purity of waters for domestic use. Many analyses of the mineral content of waters have been made by the State Water Survey, but these are mainly of well waters.

The railroads of the State have made many partial analyses of all sorts of waters in their efforts to obtain for locomotive boilers those that are least injurious. The samples of the river waters are selected usually at random or in the driest seasons. 'T'lus, with a very large number of partial analyses available, it was not possible to learn definitely just what might be expected in the way of water at any point on any river in the State.

\section{COOPERATIVE WORK.}

As part of an investigation ${ }^{a}$ of the quality of surface waters in the United States, the waters of the State of Illinois were studied as one unit. A cooperative agreement for one year was entered into July 1, 1906, between the United States Geological Survey, the State Water Survey of Illinois, the engineering experiment station of the University of Illinois, and the State Geological Survey of Illinois. This agreement called for the investigation of mineral and organic constituents of the surface and ground waters of the State, together with eyperimental work on the action of waters in steam boilers, the purification of waters for industrial and domestic use, and other similar problems. Edward Bartow, director of the State Water Survey of Illinois, was designated as administrative director of the investigations to be carried on under the agreement. The writer was assigned to the investigation of surface waters, and began work in Illinois July 16, 1906. The points for the collection of samples had already been decided by the board of control of the cooperative work, consisting of M. O. Leighton for the United States Geological Survey, Edward Bartow for the State Water Survey, L. P. Breckenridge, Arthur N. Talbot, and Samuel W. Parr for the engineering experiment station, and 
H. Foster Bain for the State Geological Survey. Arrangements were made at once for the collection of daily samples at 26 stations on rivers and at reservoirs, Doctor Bartow enge,ging collectors at the stations in the northern part of the State and the writer arranging for the collections on the rivers in the central ard southern parts. Owing to lack of funds the United States Geological Survey was unable to renew the agreement for another year, so that the analytical work after June 30,1907, was carried on by the other parties to the cooperation. This report gives the results of analyses of these samples of water, together with such other material as is necessary to make the figures of value.

\section{ACKNOWLEDGMENTS.}

The analyses of river waters were made in the laboratory of the Illinois State Water Survey by the writer until April 18, after which time they were made by Mr. C. K. Calvert. Other analyses have been obtained from the United States Geological Sirvey laboratories engaged in similar investigations in 1906-7. In the descriptive matter free use has been made of various publications of the Weather Bureau and the Bureau of the Census, and especially of the works of Palmer ${ }^{a}$ and Leverett ${ }^{b}$ on the waters of Illinois.

\section{PHYSICAL FEATURES.}

\section{TOPOGRAPHY.}

Illinois is a flat State. It is the lowest of the North-Central States, having a mean elevation of 600 feet, whereas that of neighboring States is from 700 to 1,100 feet. $^{c}$ In general, it slopes from north to south, with no pronounced changes in elevation. The most prominent ridge in the State is the Ozark uplift, in the southern part of the State, crossing from a point near Shawneetown, on the Ohio, to Grand Tower, on the Mississippi. This strip of elevated land, hardly 10 miles wide, stands about 300 feet above the neighboring tracts. The main features of the surface over the greater part of the State are due to the deposits of material left by the glaciers which once covered the State nearly to the Ozark uplift. In the lower portion, as far north as St. Louis, the drift is so thin as to exert little influence on the streams, but in the region north from St. Louis nearly all the stream courses are through this glacial drift. The elevations in this section show the amount of cutting which has been done by the streams.

a Palmer, A. W., Chemical survey of the waters of Illinois, University of Illinois, 1904.

${ }^{b}$ Leverett, Frank, The Illinois glacial lobe: Mon. U. S. Geol. Survey, vol. 38. 1899.

c Leverett, Frank, The water resources of Illinois: Seventeenth Ann. Rept. U. S. Geol. Survey, pt. 2 1896, p. 703. 
HYDROGRAPHY.

Except for the run-off of about 6,000 square miles in Wisconsin and about 3,000 square miles in Indiana and water from Lake Michigan equivalent to the drainage of 6,000 to 7,000 square miles, the rivers of Illinois carry only water precipitated within the boundaries of the State. Nearly all the drainage of the State is to the west and south into Mississippi River, but a small area is drainec' by streams flowing to the southeast into Wabash and Ohio rivers.

Rock River drains about 5,000 square miles in Wisconsin and a somewhat larger area in the northeastern part of Illinois. It discharges into the Mississippi at Rock Island.

Illinois River has the largest drainage basin in the State. The Chicago drainage canal and Desplaines, Kankakee, Fox, Vermilion, Mackinaw, Spoon, and Sangamon rivers all discharge into the Illinois, which carries into the Mississippi at Grafton the drainage from nearly half the State. The direct drainage into the Mississipf $i$ is small.

Kaskaskia and Muddy rivers drain the western half of the area from a little above St. Louis to the Ozark uplift.

Cache River is the largest stream draining the ares, below the Ozark ridge. The eastern half of the State, as far north as Champaign County, is drained into the Wabash througl: Vermilion, Embarrass, and Little Wabash rivers. Each of these streams will be considered in detail as regards the amount of flow, the quality of the water, and the value of the stream as a source of supply. Owing to the thorough cultivation of the land, the stream flow throughout the State is highly variable. There is nearly always a period of low water in the heated term, when the evaporation and atsorption are greatest. During the winter, when the precipitation is light, the streams have another period of low water. The greatest floods occur in the early spring with the thawing of the ground, melting snow, and heavy rains. There is often a later flood in June and a slight rise above the normal in the early fall.

\section{CLIMATE.}

On account of the uniform elevation of the State, the climate is very largely determined by the latitude. The mean annual temperature decreases regularly from $58^{\circ}$ at Cairo to $48^{\circ}$ at $\mathrm{C}$-icago. The mean temperature at Springfield is $52^{\circ}$. The summers are hot and the winters cold, the range of temperature being from about $105^{\circ}$ to $-20^{\circ} \mathrm{F}$. The average annual rainfall is 36.5 inches. For the southern section the average is 39 inches, for the central district 36 inches, and for the northern district 34 inches. The period from August 1, 1906 , to July 31,1907 , was one of exceptional rainfall, the average 
for the State being 44.2 inches, 7.7 inches more than the mean annual rainfall. In every month of this period, except February, the rainfall in the State was nearly equal to or greater than the average. Table 1 shows the average temperature and rainfall for each month of the period.

TABLE 1.-Average temperature and precipitation in Illinois, by months, August, 1906, to July, 1907.a

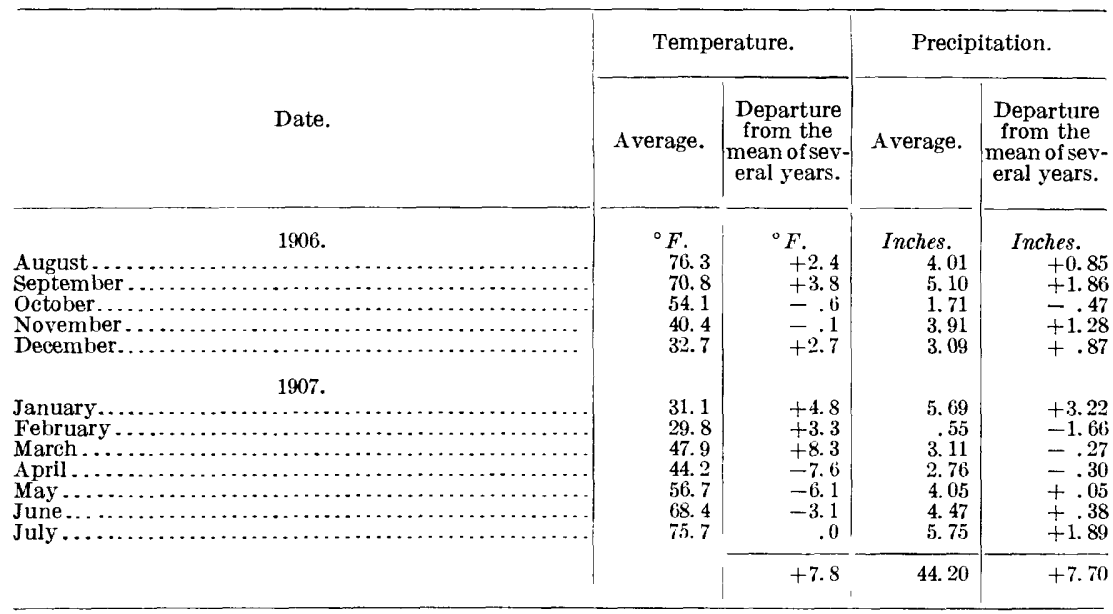

a Monthly Weather Review, U. S. Weather Burea1.

GEOLOGY.

All except the extreme southern part of Illinoir is covered by glacial drift. This mantle varies in thickness from a few feet at the southern extremity to about 200 feet in the northern part of the State. It is made up of clay, gravel, and sand, with bowlders and in some sections layers of soil buried some distance below the surface. Alden, ${ }^{a}$ in a study of this material in southern Wisconsin, made many analyses of the pebbles. He collected from 50 to 200 pebbles at random in a given region, divided them into groups according to the different kinds of rock represented, and calculated the percentage of each kind. In nearly every lot he found that over two-thirds of the pebbles were of some form of limestone very high. in magnesium. With the exception of the rapid run-off immediately after a rain, the greater part of the water flowing in the rivers of Illinois has come through this glacial drift. The high magnesium content of the drift would account for the fact that the waters flowing in these streams contain a larger proportion of magnesium than do the waters of many other rivers.

a Alden, W. C., The Delavan lobe of the Lake Michigan Glacier: Prof. Paper U. S. Geol. Survey No. 34, 1904. 
The glacial drift is a source of water supply for many of the inhabitants of Illinois. Over large areas in the north-central part of the State deep wells in the drift furnish an abundant supply of water. Beneath the drift the most important geologic division in the State is the Pennsylvanian series. This contains the coal which makes up so large a part of the natural wealth of Illinois. In the coal-bearing portions of the State there is very little underground water. Wells 10 to 20 feet deep furnish individual supplies, but cities have to rely on reservoirs which impound the drainage of small areas. The important water-bearing rocks are too deep to be easily reached, and where water has been found it has contained so much dissolved mineral matter that it has proved unsatisfactory.

In the northern part of the State two water-bearing formations are available as sources of supply-the St. Peter sandstone, of Ordovician age, and the older, deeper-lying Potsdam sandstone. The St. Peter sandstone appears at the surface in southern Wisconsin and dips rapidly to the south. It is a porous bed, and the water reaching it in southern Wisconsin is absorbed and transmitted southwerd. Where not drawn on too heavily, this water will rise nearly to the surface in Illinois when tapped by wells. Wells obtaining water from the St. Peter sandstone are about 1,000 to 1,500 feet deep, those farthest south being generally the deepest. In the northern part of the State, at depths of 2,000 to 2,500 feet, water is found in the Potsdam sandstone, which is the surface rock over much of central and northern Wisconsin. The thickness of this sandstone is not known, but it furnishes an abundant supply of water. The various limestone deposits between the St. Peter and Potsdam sandstones and above the St. Peter sandstone are used in only a few places as a source of water supply. As the Potsdam and St. Peter sandstones appear to be shallow-water or shore deposits they contain varying quantities of salts, so that in some places the waters that they yield are briny. At some places the St. Peter sandstone will furnish batter water, while at others the Potsdam will do so.

\section{ECONOMIC FEATURES.}

POPULATION.

The distribution of population in Illinois is largely dependent on the surface water supplies. At the time of the census of manufactures in Illinois in 1905 all but 1 of 11 cities with 20,000 or more inhabitants were situated on Lake Michigan or on some of the larger rivers of the State. Of 21 cities with populations between 8,000 and 20,000 only 7 were not situated on a large river or the lake. This concentration of population in the cities located on streams and the lake may be due in part to the advantages of such locations 
in the way of cheap transportation and power, but that factor can not be of great importance, for at the present time very little water power is utilized in the State, and transportation by water is of importance to very few cities. In all these cities, on the other hand, a large amount of water is used for manufacturing purposes, and the abundant supply available in such locations is undoubtedly one of the chief causes of their growth. Supplies of water from sources other than rivers and lakes are usually so small as to limit the population served by them to a low figure, beyond which increase is scarcely possible. This fact will always count strongly in favor of the river and lake cities in the establishment and extension of manufacturing plants and the increase of population necessary for conducting them.

\section{AGRICULTURE.}

On account of the richness of the soil the wealth of Illinois is very largely derived directly or indirectly from agricultural pursuits. The greater part of the State is covered with a rich black loam, which is especially well suited for growing corn. The southern part of the State does not have so rich a soil as the northern and central parts and produces somewhat more varied crops. The climate is favorable for raising cereals. In 1900 Illinois produced nearly 70 per cent of all the corn grown in the United States, 7 per cent of the wheat, and 22 per cent of the oats. This excessive production of corn accounts in some measure for the extent of the distilling industry in the State. The magnitude of the dairy business naturally follows from the great fertility of the soil. Many large dairy farms are necessary to supply Chicago and the other cities with milk and butter. In addition to supplying the demand within the State, the dairies of Illinois produce large quantities of butter and condensed milk, which are shipped to many different points in the United States.

\section{MINES.}

In addition to the wealth derived from the ground by growing plants, Illinois has a large store of mineral wealth under the ground in the form of coal, with smaller amounts of oil and lead and zinc ores and large amounts of undeveloped material, such as clays.

Nearly three-fourths of the State is underlain by productive coal measures. The working of the coal mines has, in some places, a very noticeable effect on the streams draining the mining regions. The effect of the mine drainage on streams in Pennsylvania has been carefully studied by M. O. Leighton. ${ }^{a}$ In Illinois there are no such serious

a Quality of water in the Susquehanna River drainage basin: Water-Supply Paper U. S. Geol. Survey No. $108,1904$. 
changes in the character of the streams. This is in some measure due to the facts that the mine regions of the State have less complete systems of drainage and that no large streams from outside flow through them. The effect of the sulphuric acid from the mine drainage may easily be seen in the analyses of the water from Muddy River at Murphysboro (Table 37). Here the value of the $\mathrm{SO}_{4}$ radicle varies from 24 to 186 parts per million at different times of the year. The variation in the value of the $\mathrm{SO}_{4}$ radicle in the water of the Mississippi at Chester was from 36 to 81 parts. The great variation in the character of the water coming from mining regions makes such water unsafe to use in steam boilers and very difficult to treat for purification either for drinking or for boiler use.

A large amount of limestone is quarried in the State. This industry has no effect on the water supplies.

Recently large amounts of oil have been produced in the southeastern part of Illinois, and the opening of the oil wells has had the usual effect on the streams. Similar conditions have been studied by Bowman ${ }^{a}$ in the Indiana oil fields. Embarrass River, which drains the oil fields, has been affected by the salt wr.ter from the wells. In Indiana some streams have been so polluted by the waste waters from oil wells that they have been abandoned as sources of municipal supply.

\section{MANUFACTURES.}

As a manufacturing State Illinois has many great advantages. Its central location makes easy the procuring of raw materials and the distribution of manufactured products. The transportation facilities of the Great Lakes and Mississippi River are of great value. Additional improvements in river courses may in time greatly increase the ease of marketing the output of the factories of the State. Illinois is very well covered by railroads which furnish transportation for raw and manufactured materials. The railroads are so numerous and the State so centrally located that they made the manufacture and repair of cars and general railroad-shop construction the twelfth industry in importance in the State at the census of 1905. As already mentioned, the natural wealth of the soil furnishes material for the manufacture of liquors, dairy products, and a small fraction of the meat products of the State.

The largest industry in Illinois is slaughtering and meat packing. In 1905 Illinois produced one-third the total value of meat products of the United States, 85 per cent of this amount being produced in Chicago. The other leading cities in this industry were Peoria and

$a$ Bowman, Isaiah, The disposal of strawboard and oil-well wastes: Water-Supply Paper U. S. Geol. Survey No. 113, 1905. 
East St. Louis. The nuisance resulting from the slaughtering industry in Chicago was a large factor in bringing about the construction of the Chicago drainage canal, the operation of which has had a marked effect on the amount and quality of water flowing in Illinois River.

Next in importance is the iron and steel industry. The extensive supply of coal makes it possible to take advantage of the ease with which iron ore can be procured and to build up the great industrial centers for the manufacture of iron and steel products. The leading cities in this industry were Chicago, East St. Louis, and Joliet. Twenty-seven establishments reported the use of 334 steam engines of 155,348 total horsepower, or an average of 5,743 horsepower for each establishment. To furnish feed water and condenser water for over 5,000 horsepower would require more than the whole supply of many small cities dependent on underground waters. Although there are several other requirements that miglt be important enough to be determining factors in the location of such plants, the need of water is enough in itself, and in Illinois the necessary supply of water can be obtained only from a large stream or lake.

Foundry and machine-shop products are next in value to the iron and steel products. The establishments are located in about the same places as the iron and steel mills, and are the next largest users of steam power.

The next industry in importance is the manufacture of distilled and malt liquors. Of eleven distilleries in the State, six are located in Peoria. These six produced in 1905 nearly $78 \mathrm{p}>\mathrm{r}$ cent of all the distilled liquors produced in the State and 32 per cent of the total quantity produced in the United States. The chief product is whisky, made from corn, which is grown in great abundance throughout the State. The manufacture of malt liquors is not so concentrated, extensive establishments being located in most of the large cities.

The waste materials from distilleries and breweries in great part find their way finally to the rivers. In some places they are discharged directly into the streams; in others they are fed to cattle and thus indirectly furnish a large amount of organic matter to the streams.

The manufacture of clothing, flour and gristmill products, agricultural implements, railroad cars, furniture, and some of the other more important products is less influenced by and has less influence on the waters of the State. 


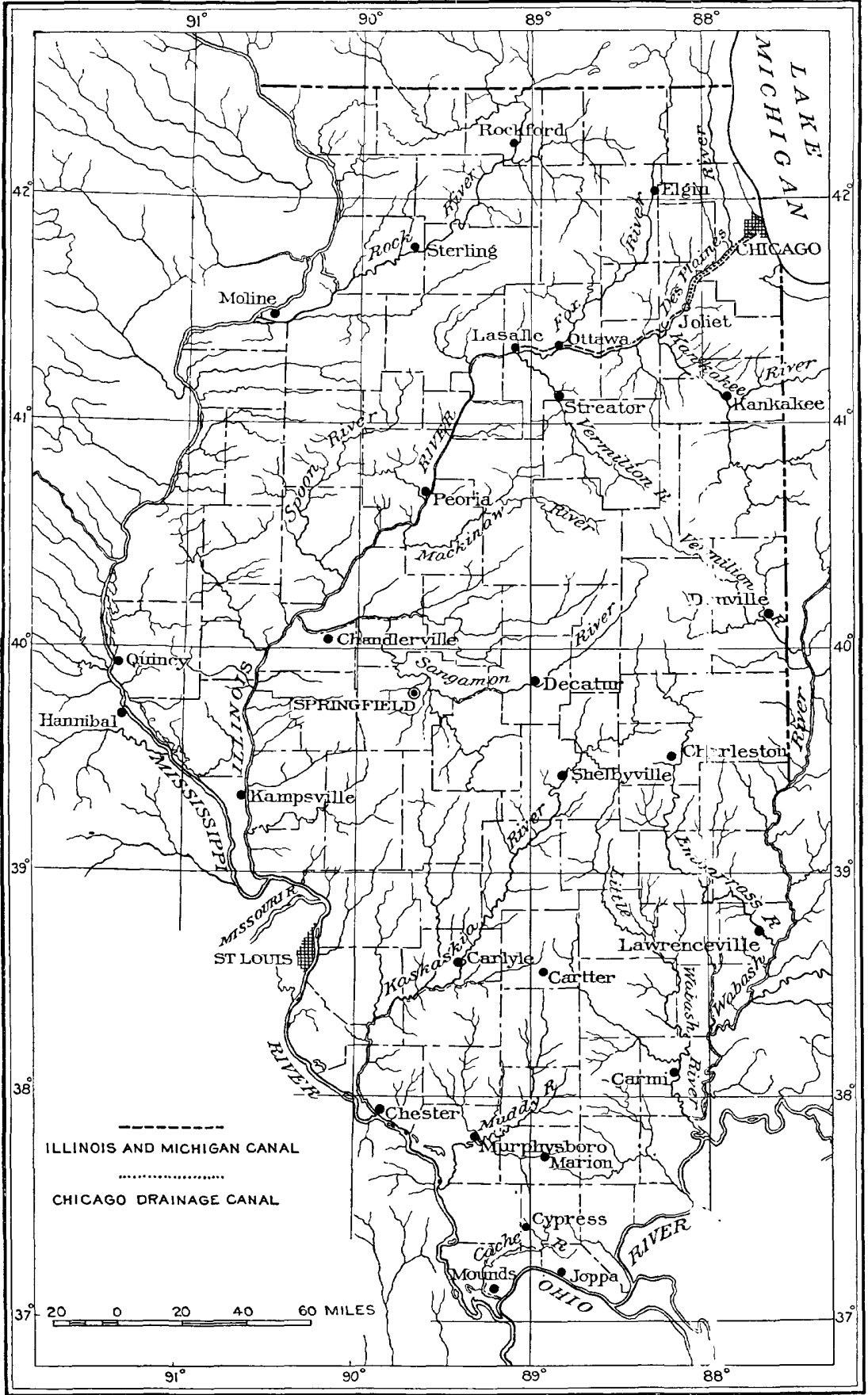

MAP OF ILLINOIS SHOWING SAMPLING STATIONS. 
Dissolved solids were obtained by weighing the residue from th evaporation in platinum of 500 cubic centimeters of filtered water.

Silica, iron, and aluminum were separated frorn the total residu in the usual manner. The silica was weighed and volatilized wit hydrofluoric acid. As a rule the iron and aluminum precipitate wa dissolved in hydrochloric acid and the iron determined colorimetric ally with potassium sulphocyanide and by comparison with perma nent standards.

Calcium and magnesium were determined in half the filtrate fror the iron and aluminum precipitate. The calcium was precipitate as oxalate, dissolved in sulphuric acid, and titrated hot with potassiur permanganate. Magnesium was precipitated as ammonium-mag nesium phosphate; after standing overnight the precipitate wa washed and dissolved in dilute nitric acid. This solution was mad alkaline to methyl orange with ammonia and nitric acid added $t$. make it barely acid. Sodium acetate was then added and the phos phoric acid titrated with uranium nitrate, with potassium ferrocya nide indicator. In some of the early analyses the addition of th phosphate was made in alkaline solution. Thes? precipitates may have contained more phosphate radicle than the amount correspond ing to ammonium-magnesium phosphate. In such a case titratin? the phosphoric acid would give too high a value for the magnesium

Sulphate and alkalies were determined in the other half of th filtrate from the iron and aluminum precipitate. The sulphate wa precipitated and weighed as barium sulphate. The sodium anc potassium were weighed as chlorides after the removal of magnesium calcium, and barium by barium hydroxide, ammonium hydroxide and ammonium carbonate. Sodium and potassium were not sepa rated.

Nitrate was determined by the phenol-sulphonic acid method.

Chlorine was determined by evaporating 100 cubic centimeter of filtered water down to 25 cubic centimeters, adding potassiun chromate, and titrating with silver nitrate solution. The strengtl of silver nitrate solution was such that 1 cubic centimeter representer 5 parts per million of chlorine.

Carbonates and bicarbonates were determined by titration witl fiftieth-normal acid potassium sulphate solution, using phenolphthal ein and methyl orange indicators. No sample during the first twi months was found to be alkaline to phenolphthalein, so its use wa discontinued throughout the rest of the year, excopt for occasiona samples, none of which was found to be alkaline to phenolphthalein

For the first month all the analytical work was $d$ one by the writer After that time assistance was furnished by the State Water Survey Until April 1, 1907, all the titrations and color comparisons and mos 
of the weighings were made by the writer. Much of the other work was done by assistants without much knowledge of cl mmistry, but with considerable skill in manipulation. C. K. Calvert conducted the analy tical work from April 20, 1907, till the completion of the analyses of the samples collected July 31, 1907.

\section{RESULTS.}

The results of the analyses are given in Tables 19 to 45 , each table containing all the analyses for one station with the averages for the year and average gage readings for stations where gages were maintained. Table 46 contains the averages for the year for all the stations. Plate II shows graphically the composition of the dry residue from the evaporation of filtered water and Plate III the relative amounts of dissolved and suspended matter. The analytical results are expressed as radicles-that is, elements or combinations of elements which take part in chemical reactions as if they were elements. Although no one can state positively how these radicles are combined in the water, and the general opinion is that to a considerable extent they are uncombined, nevertheless the metallic or basic radicles, as calcium, magnesium, and sodium must be present in quantities equivalent to the total quantity of acid radicles-chlorine, nitrate, sulphate, and bicarbonate radicles. In a careful analysis the sum of the radicles as determined minus the half-bound carbonic acid will be nearly equal to the weight of the residue at $180^{\circ} \mathrm{C}$. On account of the large number of analyses made in a short time and the amount of work done on them by persons who were not chemists, many of the analyses when completed would show that they did not represent accurately the character of the water. Many analyses were not complete on account of the small number of daily samples reneived during the ten-day period. The omission of analyses or determinations in the tables of results is due largely to failure to receive the samples, though some samples were lost in the laboratory and a few determinations have been rejected because they show very clearly that they are erroneous.

\section{DETAILED INVESTIGATIONS.}

LAKE MICHIGAN.

Drainage.-Lake Michigan receives the drainage of only a very small portion of Illinois. The amount of water carried from the lake by the Chicago drainage canal is much greater than that received from the small area of the State draining into the lake. The greater part of the drainage into the lake enters from Michigan and Wisconsin. The total area of the Lake Michigan drainage basin is estimated $28987-$ IRR $239-10-2$ 
at 68,000 square miles, of which 22,400 square miles is lake area. Thus, if the rainfall were uniform over the whole basin, about onethird of the water reaching the lake would be pure rain water. This would cause a notable dilution of the water fed to the lake by streams emptying into it. To a certain extent the effect of this dilution is counteracted by the greater evaporation from the lake surface than from the surrounding land.

Municipal supplies.-Along the shore of the lake are situated establishments furnishing over one-half the manufactured articles produced in the State. Most of these industries are losated in Chicago, but there are important factories at Evanston, Waukegan, and other cities along the shore. The leading position of Chicago as a manufacturing center is due in large measure to her excellent railroad facilities, but the lake transportation is of importance to certain industries. Hardly any other source in Illinois would supply enough water for the manufactories bordering the lake, and no other source could offer water of so good a quality except in comparatively small quantity. More water is used from Lake Michigan than from any other single source in Illinois. The cities of Chicago, Evanston, Fort Sheridan, Highland Park, Lake Forest, North Chicago, Pullman, Waukegan, West Hammond, and Winnetka, with a total population of $3,000,000$, draw their municipal supplies from the lake. All along the lake front there is a supply of underground water at depths of 1,000 to 2,000 feet, but in many places this water, while safe to drink, contains so much dissolved mineral matter as to render it unfit for most industrial uses. This deep-well supply, however, is not sufficient for any large community.

Quality of water.-In the past there has been danger in the use of the lake water for drinking because the intakes were too near the shore and sewage was allowed to flow into the lake. The opening of the Chicago drainage canal was a great advance in keeping the water of the lake pure, and there is now a steady effort to prevent pollution. As the lake water is sufficient for any community and is almost the best water available in the State for industrial uses, it naturally follows that all the cities and States located on the lake have a vital interest in keeping the water pure enough for domestic use.

The water of Lake Michigan has been so carefully studied in former years that no analyses were made for this report. The character of the lake water is nearly constant, so that one analysis is as good as a large number.

Certain determinations were made on the Chicago city supply for a number of years in connection with work on the Chicago drainage canal. Analyses were made of samples collected each week from 

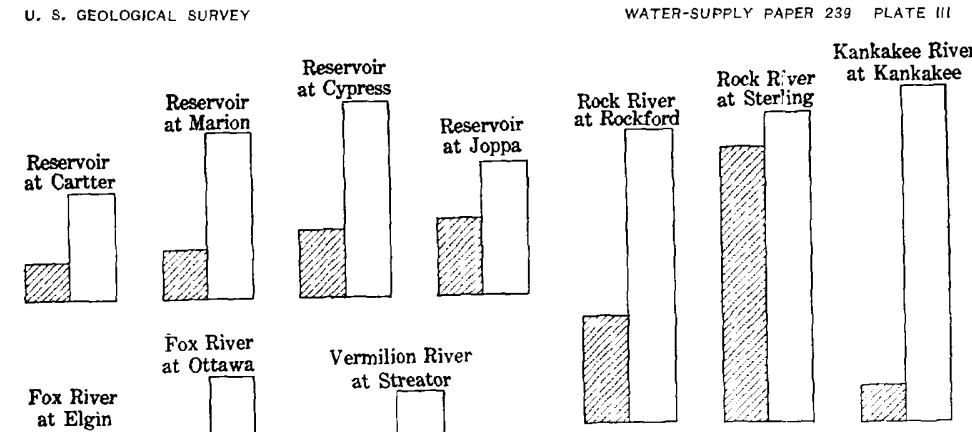

Fox River

Fox River

$$
\text { Vermilion River }
$$

at Elgin

at Ottawa at Streator

Sangamon River Sangamon River
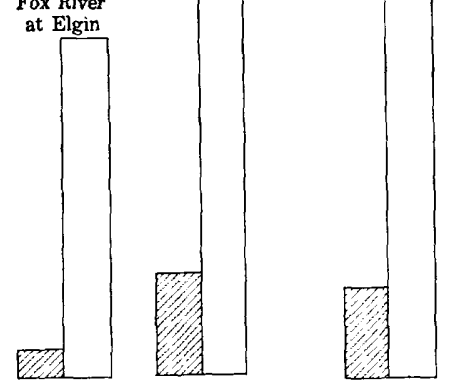

Illinois River

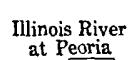

Illinois River at Lasalle at Peoria at Kampsville
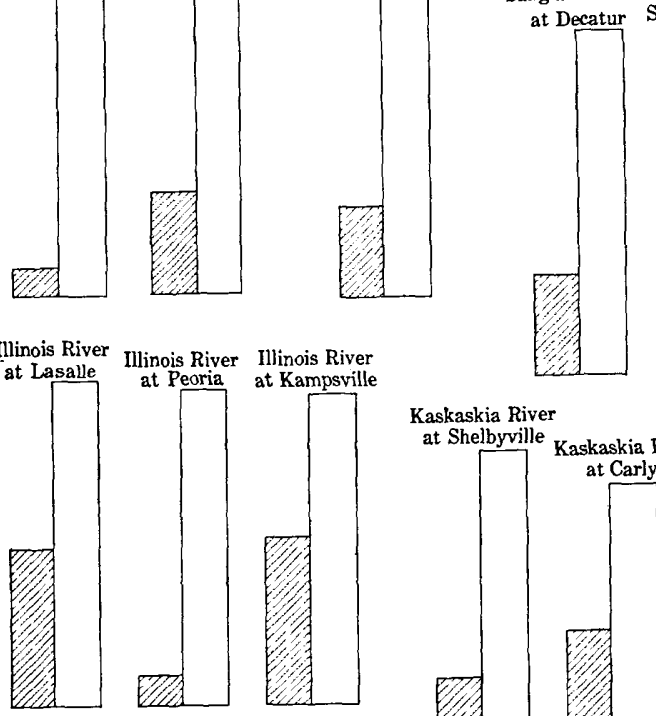

\section{at Springfield Chandlerville}
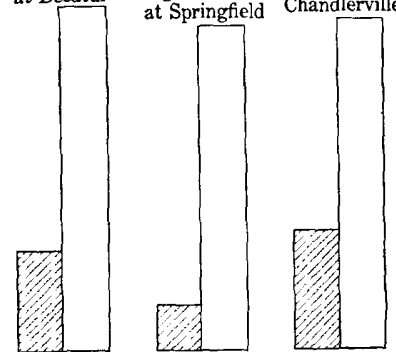

\section{Kaskaskia River} at Shelbyville Kaskaskia River

Muddy River
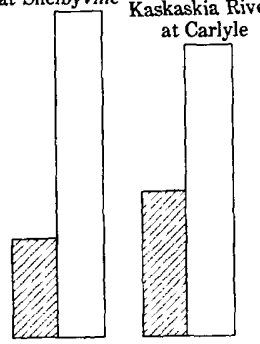

Embarrass River
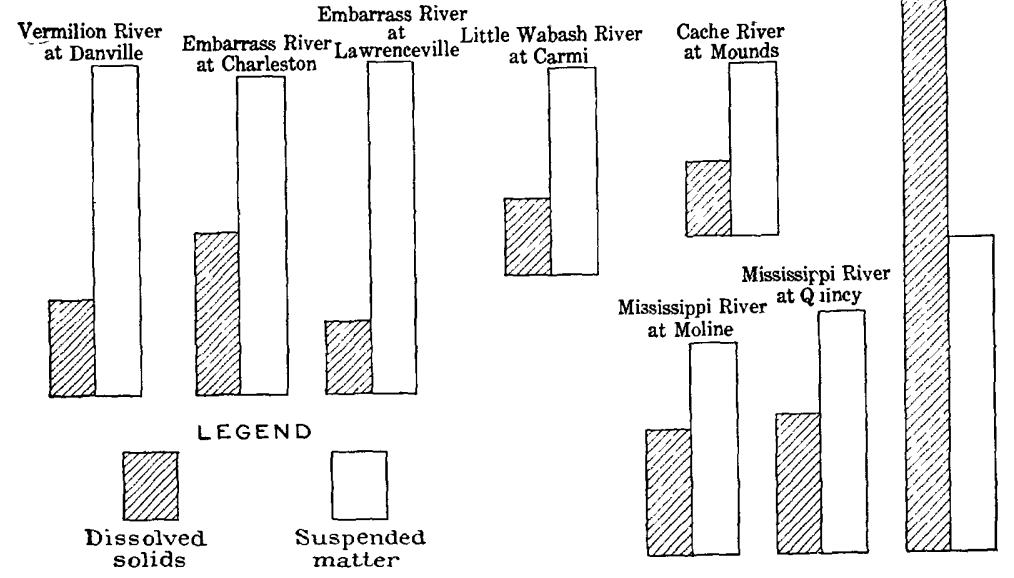

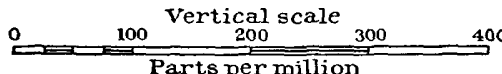



January 4, 1897, to December 26, 1900. The average values for dissolved solids and chlorine for the years stated were as follows: ${ }^{a}$

TABLE 2.-Partial analyses of Chicago city water supply.

[Parts per million.]

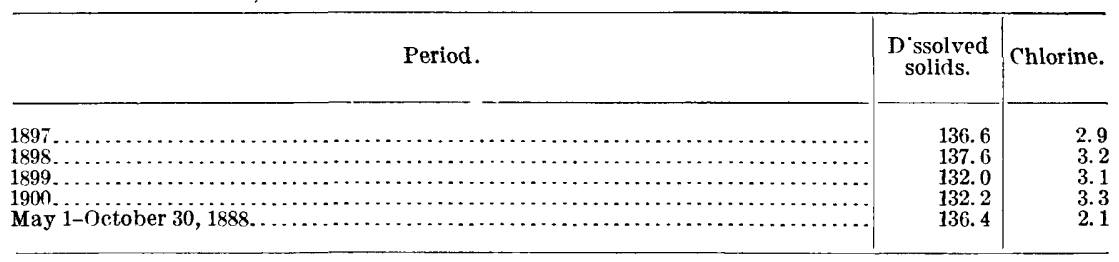

These results would indicate that the amount of mineral matter in the water of Lake Michigan at Chicago does not vary much from year to year. Below is given an analysis by Long of the mineral content of the lake water:

Analysis of Lake Michigan water. ${ }^{b}$

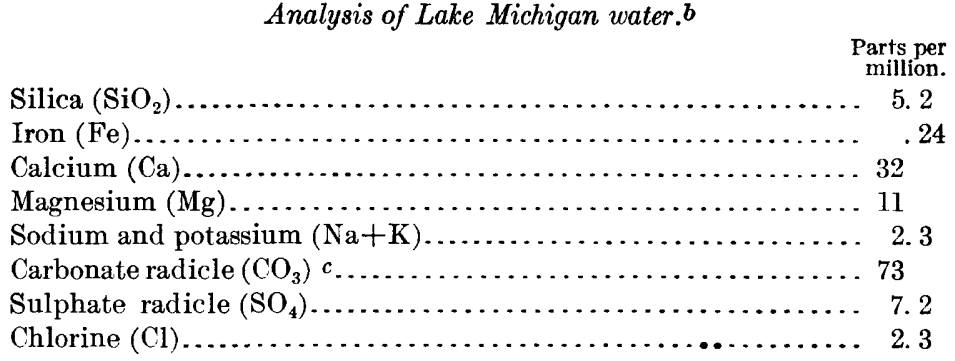

With the exception of certain small reservoirs, no supply of water in the State contains less dissolved mineral matter than the lake water. Most of the waters used in the State contain twice as much of material that will form scale in steam boilers, and nearly all are much more turbid than the lake water as delivered to the consumers in the cities where it is used.

\section{RESERVOIRS.}

Distribution and use.-Throughout the greater part of southern Illinois there is no abundant supply of water. Individual needs are met by shallow wells, which are liable to fail in dry weather and which do not furnish enough water for large communities. In this section of the State there is no underground water that is available and suitable for domestic and industrial use. Thus municipalities not located on streams of good size have been compelled to obtain

$a$ Long, J. H., Chemical investigations of water supplies of Illinois, 1888-89.

$b$ Long, J. H., op. cit., 1885, p. 7.

$c$ Probably present as the bicarbonate radicle; equivalent to 148 parts $\mathrm{HCO}_{3}$. 
their supplies through the use of impounding reservoirs. Eleven cities, with a population of 26,000 , obtain their city supplies from such reservoirs.

Samples.-Through the kindness of R. S. Charles, division engineer of the Chicago and Eastern Illinois Railroad, at Salem, Ill., arrangements were made for the collection of samples from reservoirs used as sources of locomotive feed water. Collections were made at Cartter, Marion, Cypress, and Joppa. Some difficulty wes experienced in obtaining samples regularly from Marion; and as the water from Marion was much the same as that from the other three reservoirs, collections at this station were discontinued after March 20, 1907.

Quality of water.-Analyses of the composite samples from these four reservoirs are given in Tables 19, 20, 21, and 22. All four furnish a very satisfactory water for boiler purposes. The greater part of the time they contain large amounts of finely divided yellow or brown silt, which is very difficult to remove by any method of filtration. This is the same material that is found in the vater from Little Wabash, Muddy, and Cache rivers. Marion is located in the midst of a mining section, a fact that probably accounts for the high value for sulphate in the analysis of the water from the Marion reservoir. For use in boilers or in any place where the color and turbidity do not detract from the value of the water, the water from the reservoirs at Cartter and Joppa is considerably better than that from Lake Michigan. These natural reservoirs give the softest water obtainable in the State, except that from carefully constructed artificial reservoirs.

ROCK RIVER.

Drainage.-Rock River rises in Wisconsin, between the upper Fox and the south end of Lake Winnebago, and flows in a southwesterly direction till it enters the Mississippi near Rock Island. The length of the river is nearly 300 miles and the drainage area approximately 11,000 square miles. About half the length and drainage area are in Wisconsin. In the upper part of the drainage basin there are numerous lakes and swamps, which tend to equalize the discharge of the river throughout the year. Practically all of the course of the river is in glacial drift. (See p. 10.) In Illinois the banks of the river expose the Silurian and Ordovician formations down to and including the St. Peter sandstone. The uniform character of the bed makes an even distribution of fall throughout its course. From its source to the point where it empties into the Mississippi there is a fall of 340 feet, making an average slope of 1.2 feet to the mile. The greatest fall in Illinois for any considerable distance is from Oregon to Sterling and Rock Falls, a distance of 36 miles, in which the average slope is 1.31 feet to the mile. In Wisconsin there is one stretch of 30 miles with an average slope of 1.9 feet to the mile. Locally there are even higher grades. 
There have been many power developments along the river, and some of the power is utilized at the present time. For the sake of the power users, the flow is regulated to a certain extent at some of the lakes in Wisconsin. The discharge of Rock River has been studied at various points in order to determine the available water power. During the period covered by the analyses in this report the only gagings made were at Rockton, where the United States Geological Survey has maintained a gage since October 1, 1906 . Gage readings had been made at Rockton during parts of several previous years, but the station was discontinued July 1, 1906, so that during the months of August and September, while samples were being collected for analysis, no gage readings were taken. From the gage readings and rating table of the Geological Survey discharges were calculated for each day from October 1, 1906, to July 31, 1907 . The average discharge at Rockton for that period was 4,450 cubic feet per second. As Rockton is about halfway down the drainage basin from the source of the river, the average discharge into the Mississippi was probably from 8,000 to 9,000 second-feet.

Industrialuses.- Rockford, the largest city on Rock River, is situated about 20 miles south of the Wisconsin line. Its chief industries are the manufacture of furniture, hosiery and knit goods, agricultural implements, foundry and machine-shop products, and glucose. ${ }^{a}$ Other cities of over 1,000 inhabitants situated on Rock River, mostly at waterpower sites, are Byron, Oregon, Dixon, Sterling, Rock Falls, and Prophetstown. Sterling and Rock Falls, being just across the river from each other, form one community for many purposes, such as water supply. At nearly all these cities some water power is used for manufacturing, but all the large establishments depend to a certain extent on the use of steam power.

Municipal supplies.--The municipal water supplies for all the cities along Rock River are obtained from wells, most of them from 1,000 to 2,000 feet deep. Analyses by the State Water Survey c $f$ samples of water from these wells show the mineral content to be much the same as that of the river water. These well waters are free from the turbidity and sewage pollution of the river water, so that the only reason for changing from the underground to surface supply would be an insufficient supply of the former. As the cities along the river increase in population and in manufacturing establishments the time may come when the underground supplies will not be sufficient. In such cases the river water can be so purified as to make an acceptable supply.

Samples.-To determine the quality of water in Rock River samples were obtained at Rockford and Sterling, the largest cities on the river in Illinois. At each place a 4-ounce bottle was filled with river 
water and mailed to the laboratory of the Illinois State Water Survey at Urbana every day for a year, begiming August 1, 1906. Samples of the river water at Rockford were furnished by Fred H. Gregory, chief engineer of the waterworks. The waterworks pumping station is located on the river bank; and the daily samples were collected from the circulating pump that furmishes water for the condensers.

The samples of water at Sterling were collected by C. A. Yohn, chief engineer of the Illinois Straw Products Company, of Pock Falls. The plant of this company is run partly on water power, but some steam power is used at all times, as the water power is not sufficient. The sample bottles were filled from a pump taking water from the river just outside the wheelhouse. Owing to the breakage and loss of bottles in the mails and to accidents in the laboratory, several analyses were not completed or seemed too irregular for use. The analyses completed in a satisfactory manner are given in Tables 23 and 24, together with average values for the year.

Quality of water.-For the sake of comparison with one another and with analyses from other rivers, the average analyses for the year at Rockford and Sterling are given in Table 3 in the form used by Clarke. ${ }^{a}$ This form of expression shows the percentage compo residue from the evaporation of filtered water from the river.

TABLE 3.-Average percentage composition of dry residue from filtered Rock River water, August 1, 1906, to July 31, 1907.

\begin{tabular}{|c|c|c|}
\hline & Rockford. & Sterling. \\
\hline $\begin{array}{l}\text { Carbonate }\left(\mathrm{CO}_{3}\right) \\
\text { Sulphate }\left(\mathrm{SO}_{4}\right) \\
\text { Chlorine }\left(\mathrm{C}_{1}\right)\end{array}$ & $\begin{array}{r}49.6 \\
8.8 \\
1.8 \\
1.6 \\
18.0 \\
10.0 \\
4.0 \\
6.0 \\
.2\end{array}$ & $\begin{array}{r}48.4 \\
9.4 \\
2.1 \\
1.4 \\
18.3 \\
10.1 \\
4.5 \\
5.6\end{array}$ \\
\hline & 100.0 & 100.0 \\
\hline Salinity, parts per million.. & 250 & 267 \\
\hline
\end{tabular}

These analyses show that the composition and amount of dissolved mineral matter are much the same at the two cities 60 miles apart. As is usually the case where a river flows through a populated region with manufacturing cities, the amounts of sodium, chlorine, and sulphate increase, as does the total amount of dissolved material. The most striking difference in the water at the two places is in the turbidity and suspended matter, the values for which are twic? as great at the lower station as at the upper one. The greatest variation between different samples from the same station are in the turbidity and suspended matter. Rivers in general grow more turkid toward their 
mouths, but at any place the turbidity may be due to local causes and not really represent the general condition of the river. If the figures for the average analysis for either Rockford or Sterling were taken to represent the average quality of the water at any point along the river in Illinois, the error would hardly amount to 10 per cent, which for any industrial purposes might be neglected.

To show the connection between the stage of the river and the quality of the water, use has been made of the discharges calculated from the United States Geological Survey gage heights. Although the distance by river from Rockton to Rockford, where the water samples were collected, is about 13 miles, the discharg? at Rockford is probably not very different from that at Rockton. In order to study the variations in amount of mineral matter carried past Rockford in solution, the amount in tons per twenty-four hours has been calculated for each ten-day period. These values are given in Table 4.

TABLE 4.-Discharge of and dissolved solids in Rock River at Rockford.

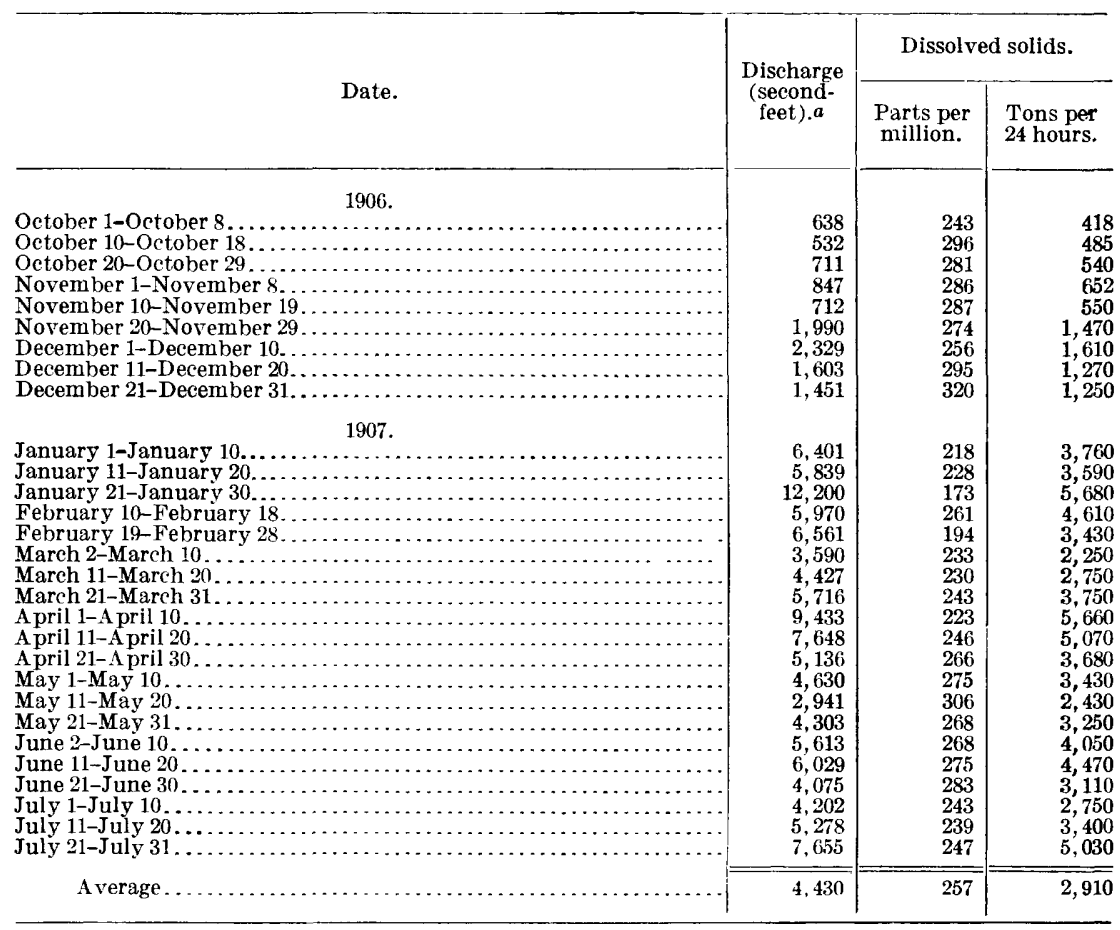

$a$ Calculated from measurements made at Rockton.

The average discharge at Rockford for the period from October 1, 1906 , to July 31,1907 , was 4,430 cubic feet per second. The average discharge at Rockton, calculated from observetions of the United States Geological Survey for a number of years, is 4,900 cubic feet per second. The average discharge at Sterling, calculated 
in the same manner, is 6,600 cubic feet per second. The average amount of dissolved mineral matter carried past Pockford from October 1, 1906, to July 31, 1907, was 2,910 tons par twenty-four hours. The amount of dissolved matter carried past Rockford annually, calculated from the figures for the average flow throughout a year and the average value of the dissolved matter for a year, as given in Table 4, is 3,300 tons per twenty-four hours, and the amount carried past Sterling is 4,760 tons per twerty-four hours. The average amount of suspended matter varies more than the dissolved matter. It is probable that the variation in amount of suspended matter is not uniform throughout the river but is largely dependent on local conditions.

The amount of dissolved matter in parts per million is the least variable of the three quantities given in Table 4 . This shows, as might be expected, that during times of high water the river has a smaller amount of dissolved mineral matter in a given amount of water. This reduction is not proportional to the increase in the flow, because an increase in flow above the normal is not caused wholly by water free from mineral matter. In tines of high flow much of the water in the river has not been on or in the ground for any considerable time, and therefore has not dissolved much mineral matter. Nevertheless it is not pure rain water.

Consideration of the amrounts of dissolved solids and the discharges for the different periods at the two stations show that these quantities are both more variable at Rockford than at Sterling. It is characteristic of normal rivers to be more variable in flow and in quantity of water near their sources than farther downstream, where the larger number of tributaries tend to equalize the flow and quality of the water.

Summary.-The water of Rock River is a good average water for Illinois. It is not safe for drinking, but could be made so. The turbidity is of such a nature as to be easily removed by moderate storage, leaving a clear water. The magnesium is high, but the magnesium and calcium are present almost wholly as carbonate or bicarbonate, so that the softening of the water for laundry purposes is a simple matter. The water forms little scale when used in steam boilers; washing out once a week with a good stream of water will keep most boilers free from it. All these things and more might also be said for the well waters in the Rock River valley, but the well waters can not be obtained in great abundance by merely running a few feet of pipe out from a pump, as those of the river can be. The easily available supply of satisfactory industrial water from the river will be a large factor in saving the more potable underground water and in increasing the amount of manufacturing carried on in the cities located on the river. 


\section{ILLINOIS RIVER DRAINAGE BASIN.}

GENERAL STATEMENT.

Illinois River drains nearly one-half the State. The direct drainage into the river is small, nearly all of its flow coming from large tributaries. The tributaries and their drainage areas are given in the following list:

Area of drainage basins of tributaries of Illinois River.

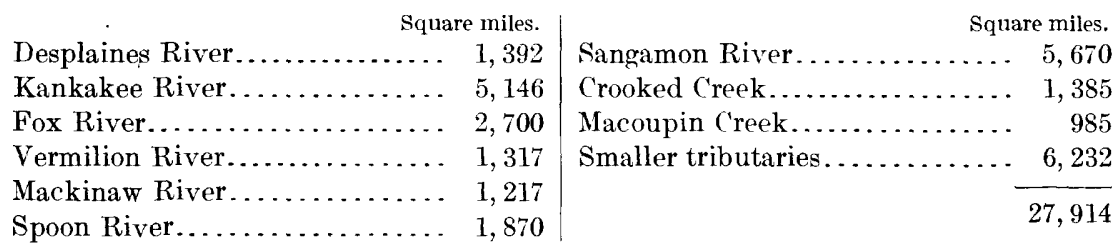

\section{CHICAGo DRAINAGE CANAL.}

Since the compilation of Cooley's report the apparent area of the Illinois River drainage basin has been increased by about 6,000 square miles. This is the area which, under normal conditions in Illinois, would furnish the amount of water which reaches Illinois River through the Chicago drainage canal. Thus it is evident that the drainage canal is one of the largest tributaries of Illinois River.

Owing to the fact that the drainage canal furnishes water from Lake Michigan, with a considerable amount of added material from the Chicago sewage, it exerts an effect on the quality of the water which is more than proportional to its drainage area. With this added material, the total dissolved mineral matter in the water of the drainage canal was found by Palmer to be about 163 parts per million, this value being obtained as the average of a number of analyses made on samples collected about every other day for a period of three months after the opening of the drainage canal. Although this is considerably more than the 133 parts per million usually found in Lake Michigan water, it is very much lower than the average for the other tributaries of the Illinois which have been examined in this work, the average solids in each of these other tributaries being over 250 parts per million. In connection with the analyses made at Peoria, the effect of the drainage canal on the character of the water can be more clearly shown. It was proved to the satisfaction of the courts that the canal exercised no injurious effect upon the quality of Mississippi River water at St. Louis. On the other hand, it was shown that the quality of the water in Illinois River is improved throughout almost all of its course by the addition of the Lake Michigan water, even with the Chicago sewage it carried.

a Cooley, L. E., 1889. The Illinois River basin in its relation to sanitary engineerirg, lllinois State Board of Health. 
DESPLAINES RIVER.

Drainage.-Illinois River is formed by the union of Desplaine. and Kankakee rivers. Desplaines River rises in Kenosha County Wis., and flows southward about as far as Chicago, where it turns tr the southwest, continuing in this direction till it joins the Kankakee The length of the river is about 90 miles. It drairs a narrow strip o land parallel to Lake Michigan, with an area of 1,392 square miles.

Municipal supplies.--The cities along the Desplaines River obtair their water supply from deep wells, except that Joliet derives part o its supply from Hickory Creek. It is not likely that the water from Desplaines River can ever be used for municipal supply, except in it upper course.

From a point below Chicago the Desplaines is peralleled by the olc Illinois and Michigan canal and the new Chicago drainage canal The Illinois-Michigan canal has always carried a large volume o Chicago sewage. Power from this canal is used at many places b? allowing the water to flow from the canal to the river, thus contamina ting the river water. At Lockport the Chicago drainage canal enter: Desplaines River, and as the flow of the drainage c?nal is often large than the other flow of the river, the character of the river water a Joliet is that of a diluted sewage.

Quality of water.-In the preparation of this report no samples wer taken from Desplaines River. From the likeness between the water: of Fox and Rock rivers, which drain the same geologic formations a: those drained by Desplaines River, it is probable that the water o the Desplaines is very similar to that found in the Fox and Rock, ir which calcium and magnesium carbonates are the chief constituent: of the dissolved mineral matter. The water of the Desplaines shou' be fairly satisfactory for industrial uses where cleanliness is not requisite. There is considerable turbidity throughout the course $c$ the river, and after it has received contamination from the Chicagc sewage it contains a large amount of offensive organic matter whicl would make it of no value for many industrial purposes.

\section{KANKAKEE RIVER.}

Drainage.-Kankakee River is, next to the drainage canal, th largest component of the upper Illinois River. It drains an area 0 : 3,200 square miles in its 85 miles of length in Indiana. The remainde] of its 140 miles of length and 5,300 square miles of drainage area art in northern Itlinois. ${ }^{a}$ The ordinary low-water dis harge is given ir the Tenth Census as 1,300 cubic feet per second. A large portion o: the area drained in Indiana and some of the area drained in Illinois is swamp land. This has a tendency to make the discharge more unj.

$a$ Greenleaf, J. L., Water power of the Mississippi River and some of its trib'ntaries: Tenth Census, 1887 p. 130 . 
form and, as a consequence, to produce greater uniformity in the amount and character of the dissolved mineral matter.

Municipal supplies.-The largest city on the river is Kankakee, where filtered river water is used for the municipal supply. The city of Wilmington also obtains its supply of water from the river. Momence, Bradley, and the smaller cities along the river find a sufficient amount of water in wells in the limestone or in the glacial drift. The manufacturing carried on in the cities along Kankalee River is of such a nature that the quality of the river water is not much affected by it. Sewage is discharged into the river by the various cities, making necessary some sort of purification before the water can . be considered safe for domestic use.

Samples.-Through the kindness of Mr. C. H. Cobb, superintendent of waterworks at Kankakee, arrangements were made for the daily collection of samples from Kankakee River. During the first part of the period covered by this report samples were obtained by dipping them from the river, but after February 19, 1907, samples were taken from the pump which draws water from the river for the raterworks. These samples from the pump were collected and mailed ky Mr. A. L. Straley. The analyses of composite samples, together with the average for the year, are given in Table 25.

Quality of water.-In the section of Indiana drained by Kankakee River are extensive beds of marl that is very nearly pire calcium carbonate. The surface rock in the northern part of Indiana and the portion of Illinois drained by the Kankakee is more nearly a pure limestone than the magnesian limestone in the areas drained by Rock, Fox, and Desplaines rivers. This character of the rock affects the composition of the water, as may be seen by comparison of the average analyses of Rock and Fox rivers with the averaga of Kankakee River. At the four stations on Rock and Fox rivers the average percentage of magnesium is 10.1, and the average ratio of magnesium to calcium is nearly 0.6. At Kankakee the magnesium is only 7.5 per cent of the total dissolved solids and is less than 0.4 of the calcium. The Kankakee water contains a larger percentage of sulphate than most of the Illinois waters. This constituent makes it a less desirable water for boiler purposes, as it is more liable to form a hard scale.

The comparative uniformity in amount of dissolved material in the river water is shown by the fact that the average difference between the values for total solids and the mean value is only 6.4 per cent of the mean value, whereas the average difference for the other rivers of the State is 11 per cent of the mean value. Owing probably to the storage in swamps and the consequent slow delivery to the river, the turbidity and suspended matter at Kankakee are very much less than are found in most of the other rivers of the State. This lower turbidity makes the water simpler to treat when it is to be purified for domestic use. 
FOX RIVER.

Drainage.-Fox River rises in Wisconsin, northwest of Milwaukee and flows southward and then southwestward into Illinois, joining Illinois River at Ottawa, 35 miles below the mouth of Kankakee River. The region drained by Fox River is almost entirely covered with glacial drift containing much magnesian limestone. The total area of the drainage basin is about 2,500 square miles, all but a small portion of which is in Illinois. Several lakes in Wisconsin, of which Geneva and Fox lakes are the largest, discharge into the river. They regulate its discharge to a certain extent, but not enough to keep it from being highly variable in Illinois.

Water power.-The Fox has less fall in Wisconsin than in Illinois. In the last 47 miles of its course there is a fall of 136 feet, and in the 5 miles above Ottawa, where it enters the Illinois, the average fall is 6 feet to the mile. There is, therefore, a large amount of water power available along the river, much of which is utilized. The feeder from a point above Dayton to the Illinois and Michigan canal at times takes almost the whole flow of the river, and on this account power from the river can not be utilized below this point. Several cities are located at power sites along the river, though the water power now in use is very little compared with the amount of steam power used in the factories of the larger cities.

Municipal supplies.-Elgin is probably the most widely known of the cities on Fox River. Besides the manufacture of watches and watch cases, there are here several plants that turn out cooperage, foundry, and machine-shop products. A large amount of general manufacturing is carried on at Aurora. The leading industry is the manufacture and repair of cars and other railroad rolling stock.

The greater part of the water used in manufacturing along Fox River is used in the production of power, largely in steam engines. For the production of steam and for condenser use the river water is as good as any other supply that can be as easily obtained. It is also abundant. The industrial establishments discharg? into the river very little material which has any noticeable effect on the character of the water.

Part of the city water supply of Elgin is taken from Fox River, the rest of it being obtained from deep wells. Analyses by the Ilinois State Water Survey indicate that the well water is somewhat better in quality than the average river water.

Elgin is about the lowest town on the stream which could use the river water as a source of municipal supply. All the cities below Elgin discharge sewage into the river, making it difficult to purify the water sufficiently for domestic use. Fortunately, throughout the course of the river there is an abundant supply of water in deep rock and in the glacial drift. 
Samples.-Samples from which analyses were made for this report were obtained through the kindness of Mr. R. R. Parkins, chief engineer of the Elgin waterworks. Samples were collected deily from the pump drawing water from the river for the filter plant. Analyses of the composite samples of the water from Elgin are given in Table 26.

At Ottawa, near the junction of Fox and Illinois rivers, samples were collected from Fox River daily from August 1, 1906, to July 31, 1907. These samples were taken by Mr. M. P. Lannigan, pumper for the Rock Island Railroad. The samples were collected from the pump at the watering station of the railroad. Analyses of the composite samples obtained at Ottawa are given in Table 27.

Quality of water.-Estimates made from figures by Cooley give the average discharge of Fox River at Elgin as 1,100 cubic feet per second. This value makes a discharge at Elgin of 860 tons of dissolved mineral matter and 68 tons of suspended matter per twenty-four hours. As calculated from Cooley's figures, the average discharge at Ottawa is 1,900 cubic feet per second. This gives a value of 1,720 tons of dissolved mineral matter and 450 tons of suspended matter carried at Ottawa each twenty-four hours. For the sake of comparison, the percentage composition of the average residue from the evaporation of filtered river water at Elgin and Ottawe, is given in Table 5 .

TABLE 5.-Percentage composition of residue of Fox River water at Elgin and Ottawa.

\begin{tabular}{|c|c|c|}
\hline & Elgin. & Ottawa. \\
\hline Carbonate $\left(\mathrm{CO}_{3}\right) \ldots$ & 46.8 & 41.4 \\
\hline Sulphate $\left(\mathrm{SO}_{4}\right) \ldots$ & 13.5 & 18.7 \\
\hline $\begin{array}{l}\text { Chlorine }(\mathrm{Cl}) \\
\left.\text { Nitrate } \mathrm{NO}_{3}\right) \ldots \ldots \ldots \ldots . . . . . .\end{array}$ & $\begin{array}{l}1.8 \\
.9\end{array}$ & $\begin{array}{l}2.4 \\
1.5\end{array}$ \\
\hline Calcium (Ca) $\ldots \ldots \ldots \ldots \cdots$ & 18.1 & $\begin{array}{l}1.0 \\
18.4\end{array}$ \\
\hline Magnesium (Mg) & 10.6 & 9.8 \\
\hline Sodium and potassium $(\mathrm{Na}+\mathrm{K})$. & 3.9 & 4.3 \\
\hline \multirow[t]{2}{*}{$\begin{array}{l}\text { Iron oxide }\left(\mathrm{Fe}^{2} \mathrm{O}_{3}\right) \ldots \ldots \ldots \ldots \ldots \ldots \ldots \\
\text { Silica }\left(\mathrm{SiO}_{2}\right) \ldots \ldots \ldots \ldots \ldots \ldots \ldots \ldots\end{array}$} & 4.13 & $\begin{array}{r}.1 \\
3.4\end{array}$ \\
\hline & 100.0 & 100.0 \\
\hline Salinity, parts ner million.... & 282 & 326 \\
\hline
\end{tabular}

The percentage composition shows that the character of the water at Elgin and Ottawa is very much the same, the differences being such as usually occur in a river passing through an inhabited region containing cities of considerable size. The percentages of sulphate, chlorine, and sodium are slightly increased and the percentage of carbonate is decreased at the lower point. The salinity-that is, the amount of mineral matter dissolved in the water-is decidedly increased. As may be seen by comparison of Tables 26 and 27 , the turbidity and suspended matter are very much greater at Ottawa than at Elgin. Even with this increase, however, Fox River at Ottawa is usually a fairly clear stream. The suspended matter of 
Fox River water is not difficult to remove, so that filtration of th water would not be attended by any special difficulties. The wate at Ottawa is not so variable in character as that at Elgin. Th average difference between the mean value for dissolved solids ar' the individual values is 8.2 per cent of the mean value at Elgin; a Ottawa it is only 7.3 per cent. The difference between the maximur and the minimum values for dissolved solids at Elgin is 50 per cen of the mean value; the difference at Ottawa is 42 per cent. Thi greater uniformity in the character of the water downstream $i$ characteristic of most rivers.

As mentioned above, the drainage basin of Fox River contains large amount of glacial drift made up very largoly of magnesium bearing limestones. This characteristic of the soil and subsoil i shown in the character of the water. Except Rock River, none o the rivers examined has so large a percentage of magnesium as Fo: River. The proportion of magnesium to calcium is about the sam for Fox and Rock rivers, but the percentage of sulphate in the Fos is larger than in the Rock. This, together with the larger amount o dissolved mineral matter, would make the water of Fox River les desirable than that of Rock River for many purnoses.. The differ ence between them, however, is not very great. To soften For River water and make it perfectly satisfactory for boiler use and for use in laundries would require only a small amount of compara tively inexpensive chemicals.

VERMILION RIVER. $a$

Drainage.-Vermilion River rises in the Blocmington moraini system, at the reentrant angle in southeastern Livingston and wester Ford counties, ${ }^{b}$ and flows in a northwesterly direction till it meet: the Illinois at Lasalle. The drainage area is about 1,410 square miles The country is fertile and well cultivated. The slope of the river ; very moderate and the flow is exceedingly irregular. It is said tha at times there is less flow at the mouth than at Pontiac, 20 miles uf the river.

Municipal supplies.-Pontiac and Streator koth obtain thei municipal supplies from the river. In each place the water is treatec with coagulant and filtered. At times of low water the whole flow o the river is utilized at Streator.

Samples.-For this report samples were collected through th kindness of Mr. R. D. Huggans, superintendent of the Streator Aque duct Company. During the first part of the period samples wer taken directly from the intake pump. Later a screen was put in ove the mouth of the intake pipe for the sake of lessening the turbidity o 
the water as delivered to the filters, and after this daily samples were dipped up directly from the river. The analyses made of the composite samples from Streator are given in Table 28.

Quality of water.-The quality of the water at Streator varies more than the water of average streams in Illinois. The amount of dissolved mineral matter is also higher than in most of the rivers. Like that of the other rivers in the northern part of the State, the water contains a large amount of magnesium. The value for the sulphate is also higher at Streator than at any of the other stations in the northern part of the State. The water of Vermilion $\mathrm{Ri} r e r$ is not so satisfactory for domestic or industrial use as that of many other streams in Illinois.

\section{SANGAMON RIVER.}

Drainage.--Sangamon River rises in the Bloomington morainic system in eastern McLean County. It drains an area of 5,670 square miles, which is mainly rolling prairie. In the first 10 miles the river has a fall of 120 feet and in the remaining 170 miles of its length a fall of 300 feet. This fall is unevenly distributed, the river laving many stretches of almost still water and other stretches of rapid flow. On account of the variability of the flow and the fact that through most of the course of the river its bed is in gravel and sand, there is almost no water power developed.

Municipal supplies.-Springfield is the largest city on Sangamon River. The population of Decatur, the next in size, is only twothirds that of Springfield, but the value of articles manufactured at Decatur in 1904 was over a third greater than the value of those manufactured at Springfield. None of the leading industries in either city is largely dependent on water for any purpose except the generation of power. The effect on the river of wastes from the factories is negligible as compared with the effect of the sewage from all the cities along the river. The municipal water supplies of Decatur and Springfield are obtained from the river. At Decatur the water is impounded by a dam, treated with a coagulant, and filtered. At Springfield part of the supply is pumped directly from the river and the remainder is obtained from filter galleries near the river.

The turbidity of Sangamon River is usually somewhat high at all points. This turbidity is not difficult to remove, and at Decatur the water is treated and furnishes a very satisfactory supply. At Springfield, where it has been used without treatment, it is not very inviting to drink nor cleansing when used for washing. Like most Illinois river waters, that of the Sangamon contains enough salts of calcium and magnesium to form a considerable amount of scale when used in boilers and to make it unsatisfactory for laundry purposes. It is not likely, however, to form much hard scale in boilers if they are prop- 
erly cared for, and the expense of treating it so as to make it suitable for laundry purposes is not very great.

Samples.-For the preparation of this report samples of water were collected at Decatur, Springfield, and Chandlerville. The collections at Decatur were made by Mr. Fred Litterer, chief engineer of the city waterworks; those at Springfield by Mr. Gus Obert, chief engineer of the city waterworks; and those at Chandlerville from the river at the crossing of the highway britge, northeast of town, by Messrs. J. W. Martin and John Madden and Miss Bessie Long. The bottles were filled by dipping the water from the stream and pouring into the bottles, until April 20, 1907, after which time the bottles were let down with a sinker and filled under the surface. Many collections were omitted at both Springfield and Chandlerville. It was difficult to determine the reasons for the om issions at Springfield. The omissions at Chandlerville were due in part to high water, which at one time covered the bridge from which samples were usually collected. Other omissions were due to illness of one of the collectors.

Quality of water.-Analyses of the composite samples from Decatur, Springfield, and Chandlerville are given in Tables 29, 30, and 31, together with averages for the year. The percentage composition of the dry residue from river water at these three points is given in Table 6.

TABLE 6.--Percentage composition of dry residue from Sangcmon River water.

\begin{tabular}{|c|c|c|c|}
\hline & Decatur. & $\begin{array}{l}\text { Spring- } \\
\text { field. }\end{array}$ & $\begin{array}{l}\text { Chand- } \\
\text { lerville. }\end{array}$ \\
\hline 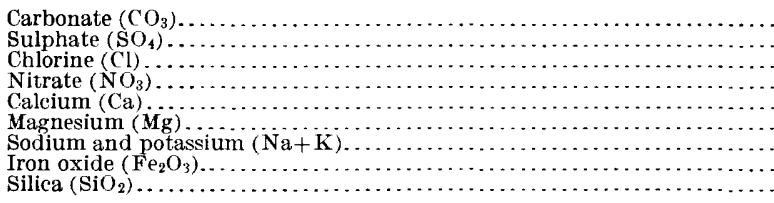 & $\begin{array}{r}44.7 \\
11.9 \\
1.8 \\
2.9 \\
18.7 \\
8.8 \\
4.7 \\
.1 \\
6.4\end{array}$ & $\begin{array}{r}43.7 \\
13.3 \\
2.7 \\
1.2 \\
18.7 \\
8.6 \\
5.8 \\
.2 \\
5.8\end{array}$ & $\begin{array}{r}44.4 \\
12.7 \\
2.7 \\
2.2 \\
18.4 \\
8.8 \\
5.3 \\
.2\end{array}$ \\
\hline Salinity, parts per million.......... & 295 & 278 & 282 \\
\hline
\end{tabular}

This shows that the water for the year is much the same throughout the length of the river. The dissolved mineral matter in Sangamon River is not very different in character from that in the other tributaries of the Illinois. The Sangamon water resembles the water of the northern tributaries more than that of the Kankakee. Owing in part to the fact that the Sangamon receives a number of large tributaries along its course, there is no particular relation between the samples at the different points of collection. The analyses at Decatur are probably of more value than those from Springfield and Chandlerville. 
ILLINOIS RIVER.

Samples.-On Illinois River itself daily collections of water were made at Lasalle, Peoria, and Kampsville. At Lasalle collections were made by Mr. James Brotherton at the Illinois Central pumping station. This pumping station is south of the city, at the point where the Illinois Central Railroad crosses the river, and is above the point of discharge of the Lasalle sewage. It is probable that at this locality the water of various tributaries is well mixed. The stream at Lasalle is made up of water from Desplaines, Kankakee, Fox, Vermilion, and Little Vermilion rivers, together with the flow from the Chicago drainage canal.

From Lasalle to Peoria no tributaries of any considerable size enter the river. In consequence, the quality of the water at Peoria is not very different from that at Lasalle. At Peoria samples were collected from the bridge across the river near the Peoria waterworks by Mr. Alfred Barton in bottles let down with a sinker and filled under the surface.

Between Peoria and Kampsville a number of tributaries enter the river. The largest of these is the Sangamon, the average discharge of which is about one-fifth of the discharge of the Illinois at Kampsville. The other tributaries entering between Peoria and Kampsville are Mackinaw River, Spoon River, and Crooked Creek. Collections at Kampsville were made by Mr. Ira Davidson, samples being obtained by dipping the water from the surface of the river midway across the stream. This method of collecting is subject to errors which have been previously discussed.

Quality of water.--The analyses of composite samples made from the daily samples at Lasalle, Peoria, and Kampsville are given in Tables 32, 33, and 34, together with average values for the year. The percentage composition of the dry residue from the filtered water at each of these stations is given in Table 7 .

TABLE 7.-Percentage composition of dry residue from fltered Illinois River water.

\begin{tabular}{|c|c|c|c|}
\hline & Lasalle. & Peoria. & $\begin{array}{c}\text { Kamps- } \\
\text { ville. }\end{array}$ \\
\hline 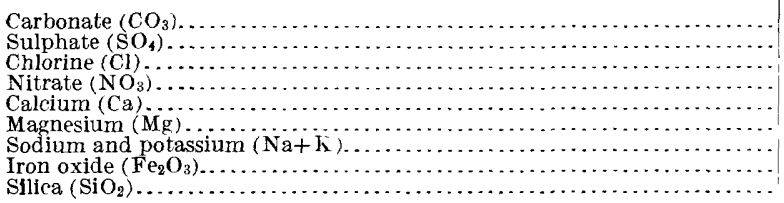 & $\begin{array}{r}37.0 \\
18.6 \\
4.8 \\
2.4 \\
18.6 \\
8.1 \\
5.9 \\
.1 \\
4.5\end{array}$ & \begin{tabular}{r|}
36.7 \\
18.1 \\
4.9 \\
2.9 \\
18.5 \\
7.9 \\
6.4 \\
.1 \\
4.5
\end{tabular} & $\begin{array}{r}38.5 \\
16.3 \\
5.8 \\
1.7 \\
18.2 \\
7.8 \\
7.0 \\
.1 \\
4.6\end{array}$ \\
\hline & 100.0 & 100.0 & 100.0 \\
\hline Salinity narts per million & 270 & 265 & 258 \\
\hline
\end{tabular}


When these results are all taken together, it is cvident, as would be expected, that the water at Lasalle and Peoria is almost the same; though the suspended matter is less at Peoria, probably owing to the facts that the river at Peoria has a very slugg:sh flow and that at the middle of Peoria Lake where the samples were collected opportunity had been afforded for the settling of the suspended matter.

Illinois River water is not so high in carbonates $\approx$ s other waters of the State, and is higher in sulphates. It also has a larger percentage of chlorine than the average waters in the State. This increase in sulphates and chlorine is probably due largely to the effect of Chicago sewage, as the tributaries above Lasalle have much lower percentages of chlorine. The variation in quality of the water is much less in the upper Illinois than in other streams in the State. At Kampsville the average variation in dissolved solids is 10 per cent of the mean value, and the range from maximum to minimum is 65 per cent of the mean value. As before stated, this is probably due in part to the method of collecting the samples. As the samples are taken just above the dam, it is possible that a ligh rainfall with quick run-off in the immediate vicinity of the point of collection would cause a dilution of the upper layer of water which would be much greater than the dilution of the whole flow of the stream. The widest difference from the average value of the dissolved solids is in one sample where the value was very low at a time of high turbidity.

Discharge.-The discharge of Illinois River at Lasalle has been measured at various times and gage readings have been taken by different branches of the government service. During the period covered by this report gage heights have been read by the Weather Bureau. From these readings and from the ratirg table prepared from a few discharge measurements made by the United States Geological Survey in 1903, discharge measurements have been calculated for each of the days when collections were made. Owing to the fact that the relation between the Weather Bureau gage and the United States Geological Survey gage had to be determined by reference to Chicago datum and Memphis datum, with various corrections to be applied, the discharge measurements aro probably not as accurate as those at Peoria, where the United States Geological Survey was maintaining a gage during the course of the analytical work.

The discharge measurements computed from measurements at Lasalle, together with the dissolved solids for each ten-day period, are given in Table 8, which shows also the amount of dissolved material carried by the river each twenty-four hours. The average variation in the discharge at Lasalle is 30 per cent of the mean value for the discharge. The average variation in the solids is 6.9 per cent of 
the average value. The average variation in the dissolved material carried by the river is 33 per cent of the mean value.

TABLE 8.-Discharge of and dissolved solids in Illinois River at Lasalle.

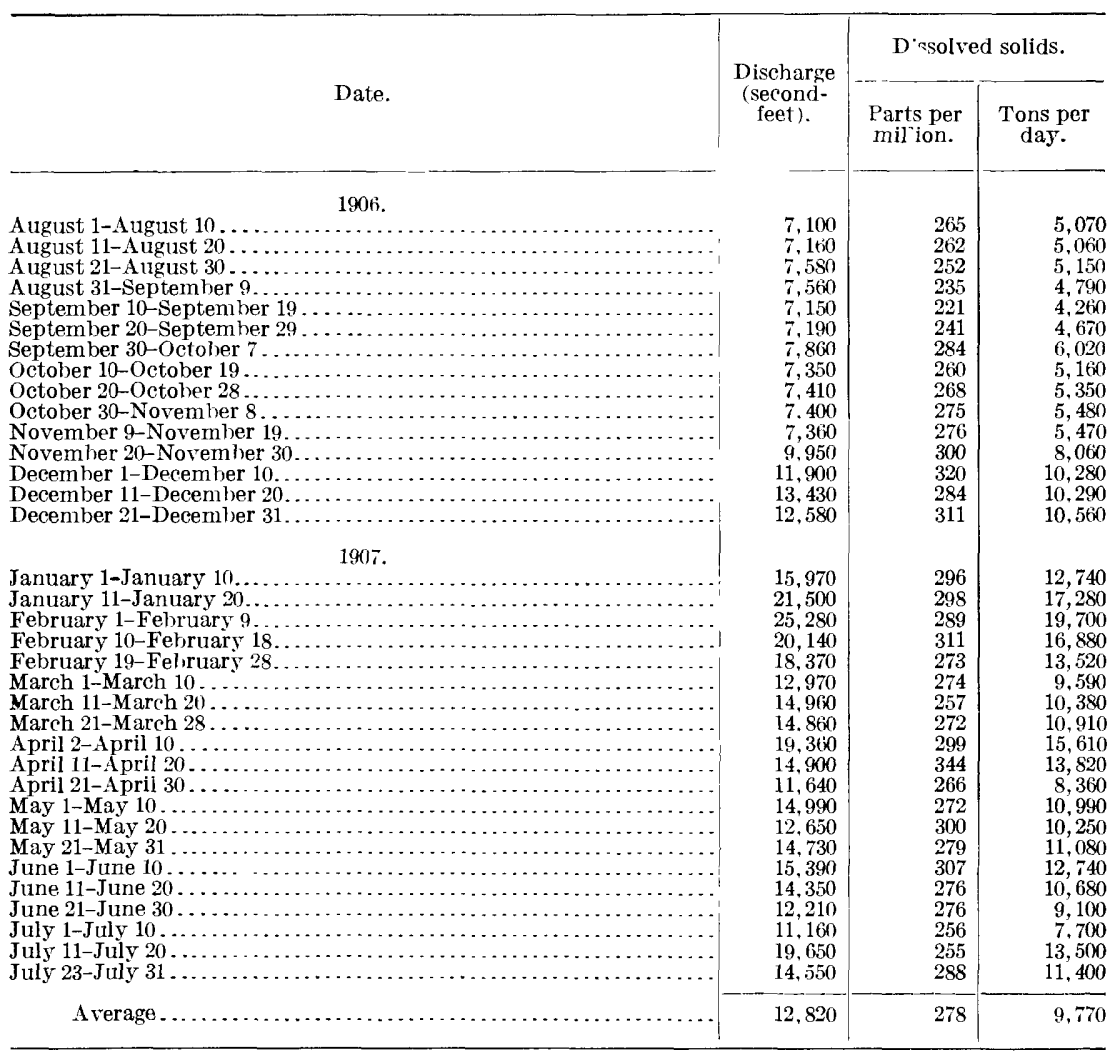

The discharge of the river at Peoria has been carefully measured for a long series of years. During the period covered by this report daily gage readings were made by an observer of the United States Geological Survey. A rating table for the river at Peoria has been prepared to cover this period. From this rating table and the gage measurements the discharge of the river at Peoria has been calculated for each day when samples were collected. Thes? have been averaged into ten-day periods corresponding to the composite samples. From the average discharge in second-feet and the value in parts per million of the dissolved solids, as determined by evaporation of the filtered water, the amount of dissolved material carried past the gaging station at Peoria by the water of Illinois River each twenty-four hours has been calculated. The figures are given in Table 9, together with the average values. The average variation in discharge at Peoria was 35 per cent of the mean value of the dis- 
charge. The average variation of the dissolved solids was 6.3 per cent of the mean value. The average variation in the amount of material carried by the river was 36 per cent of the mean value.

TABLE 9. -Discharge of and dissolved solids in Illinois River at Peoria.

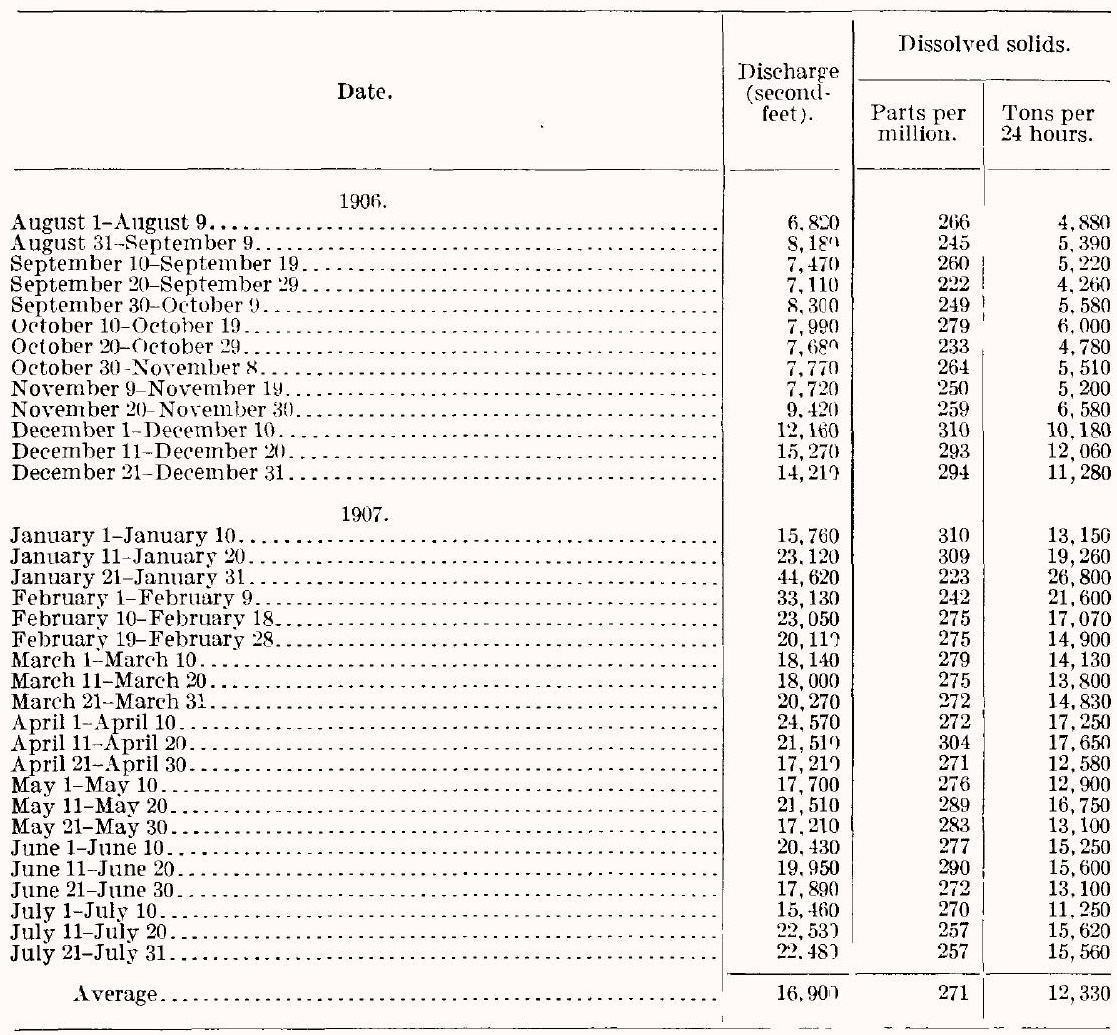

Tariation in quality. - In the flow of an ordinar river it is usual to expect the lowest value for the dissolved solids, the highest value for the suspended solids, and the highest value for the discharge to come at about the same time. In times of low water the river is fed largely by springs or by water which reaches the river through infiltration from the sides and through the bed. This ground water is naturally clear, and by reason of its passage through the ground has dissolved a considerable amount of mineral matter. In times of storm a large proportion of the water which falls drains immediately into the river. As it runs quickly over the surface of the ground it picks up loose material, so that upon entering the stream it carries a large load of suspended matter, while it has had time to dissolve very little. This makes the water of the stream high in turbidity and low in dissolved solids. On this account one vrould expect that the amount of dissolved material carried by a given point in a river 
would be much less variable than the discharge of the river. If, in time of flood, the discharge of the river is five times the low-water discharge, the amount of dissolved material carried by the river will rarely be five times as great. On the other hand, the volume of four times the low-water flow which has been added to the low-water flow is not pure water. Therefore the amount of dissolved material carried by the river will be very much greater than the amount carried in low water. Rock River at Rockford (see p. 23) is an illustration of a normal river.

Illinois River at Lasalle and Peoria shows very deciderlly the effect of the Chicago drainage canal in maintaining the uniformity of quality of water. Although the values for the average variation in discharge at these two points are 30 and 35 per cent, respectively, the variations in amount of material carried are 33 and 36 per cent. This indicates that the water of Illinois River in time of flood has a tendency to carry more dissolved material than at times of low flow. This results from the fact that nearly ono-half of the low-water flow of Illinois River at Lasalle and Peoria is furnished by the Chicago drainage canal, which contains on the average about 160 parts per million of dissolved solids. This, combined with an equal volume of low-water flow from Desplaines, For, Kankakee, and Vermilion rivers, gives a resulting water which is still low in dissolved solids, although the other tributaries carry probably over 300 parts per million. The average amounts of dissolved solids carried by three of these rivers are as follows: Fox, 335 parts per million; Kankakee, 288 parts; Vermilion, 325 parts. It is probable that the natural water of the Desplaines carries about the same amount of dissolved solids as the other tributaries. Even the high-water flow of these tributaries carries much more dissolved solids than the Chicago drainage canal. Thus it comes about that in many cases a rise in the river is accompanied by an increase in the proportion of dissolved solids, which makes the amount of material carried past a given point increase faster than the discharge.

These results at Peoria and Lasalle show one benefit of the Chicago drainage canal, which has possibly been overlooked in considering the many changes which have resulted from its opening. One of the objections to the use of river water for industrial purposes or for a municipal supply, where it is necessary to treat the water, is that the variation in character of the water from day to day and from season to season is so great that any treatment of the water based on the results of only a few examinations is liable to be unsatisfactory for a great part of the time. Any change in quality of the water will require a change in treatment, and some river waters are so variable in quality that it would be useless to attempt to treat them without expert chemical supervision; it would be necessary to test the water 
each day and apply the chemicals in amounts determined by these tests. For a uniform water, such as a deep-well water or many ground waters, a single analysis suffices to determine the kind of treatment and the amount of each chemical necessary to add, thus making it possible to handle a water-purification plant with much less expense for supervision. A river water as constant in character as the Illinois at Peoria and Lasalle, however, might be given an average treatment-that is, a treatment based on the results of an average analysis, such as are given in this report. This treatment would probably be better than a varying treatment determined from day to day by a person not very skilled in chemical manipulation.

Municipal supplies.-Illinois River water is not used for municipal supply, but a very large amount of it is used by various manufacturing establishments along the river. Practically all the cities on the river are able to obtain a supply of underground water which has almost the same mineral content as the river water and at the same time is free from pollution. It is doubtful if the time will ever come when Illinois River water will be looked upon with favor as a source of municipal supply. The large amount of sewage in the Chicago drainage canal would make people hesitate to undertake the purification of the water. As was shown in the investigations in connection with the lawsuit over the drainage canal, ${ }^{a}$ a large amount of organic matter enters the river at Lasalle, Peoria, and Pekin-more, at the time of Palmer's investigations, than that entering through the Chicago drainage canal. It is possible that in the lower part of the river the water might be used safely for municipal supply, provided it were properly purified.

\section{KASKASKIA RIVER.}

Drainage.-Kaskaskia River rises in the Champaign morainic system, immediately west of Champaign, gradually descends from an elevation of 730 feet to 542 feet, and enters the I Iississippi above Chester in Randolph County. About 590 square miles of comparatively level area are drained by the river in its length of 180 miles. $^{b}$

Because of its variations in flow Kaskaskia River has never been used to any great extent as a source of power. At Carlyle, during the year covered by this report, there was a rise of 23 feet in the river. In the summer time it often runs nearly dry in some parts of its course. A careful survey has been made by the Illinois State Geological Survey, with the object of determining a metkod of treatment of the Kaskaskia River bottoms so as to reclaim a large amount of land which is now flooded so frequently as to render it practically useless for agricultural purposes. If this land is rerlaimed, the discharge of the river will be more variable than at present. 
Municipal supplies. - Vandalia and Carlyle are supplied with water from Kaskaskia River. Shelbyville formerly obtained its supply from the river, but now takes water from wells in the gravel near the river. This water, intercepted on its way to the river, has much the same character as that of the river and is free from turbidity. In the river water at Shelbyville the turbidity averaged over 100 parts per million during the year corered by this report.

Samples.-Daily samples were collected from the river at Shelbyville by Mr. Isaac Nutt, engineer of the Shelbyville Water Company, by dipping water from the river at a point directly opposite the waterworks. An old dam, partly destroyed, crosses the river at this point, and the water was dipped from a broken place in this dam, through which the stream flows rapidly. Through the kindness of $\mathrm{Mr}$. Chester, superintendent of the water company, a gag 3 was erected on the river near the waterworks and daily readings taken from it.

At Carlyle, about 70 miles down the river from Shelbyville, samples were collected from the pump at the waterworks, the intake pipe of which extends about 400 feet upstream. Mr. George Schilling, superintendent of waterworks, collected the samples. A gage was fastened to a tree near the bank of the river and rendings of the height of the water were made daily after November 3,1906 .

Quality of water.-Analyses of the composite samples from Shelbyville and Carlyle are given in Tables 35 and 36 . The percentage composition of filtered water at Shelbyville and Carlyle is given in Table 10 .

TABLE 10.-Percentage composition of dry residue from filtered Kaskaskia River water.

\begin{tabular}{|c|c|c|}
\hline & $\begin{array}{l}\text { Shelby- } \\
\text { ville. }\end{array}$ & Carlyle. \\
\hline 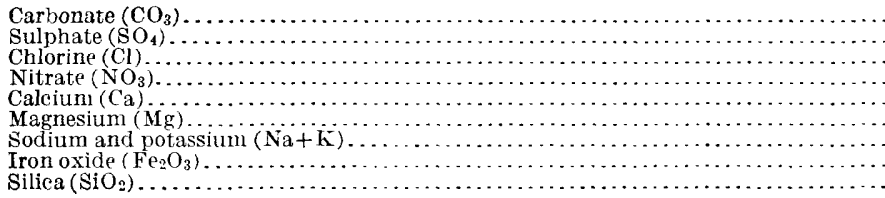 & $\begin{array}{r}45.4 \\
12.0 \\
2.0 \\
2.4 \\
18.7 \\
9.2 \\
4.6 \\
.1\end{array}$ & $\begin{array}{r}\text { 42. } 1 \\
13.7 \\
2.8 \\
1.9 \\
18.9 \\
8.0 \\
5.6 \\
6.2 \\
6.8\end{array}$ \\
\hline & 100.0 & 100.0 \\
\hline Salinity, parts per million . . . . . . . . . . . . . . . . & 284 & 249 \\
\hline
\end{tabular}

Kaskaskia River water is a typical Illinois water. There is no very great difference in the character between the samples at the two stations, the range in dissolved solids being about the same at each. The average variation, however, is greater at Carlyle, being 11 per cent of the mean value, while at Shelbyville it is only 7.8 per cent. The water is more suitable for boiler use than for laundris. It forms very little or no hard scale in boilers when they are cleaned often enough. Treatment with lime alone in the proper quantities would very much improve the quality of the water for laundry work. 


\section{MUDDY RIVER.}

Drainage.-Muddy River drains an area of nearly $\Sigma, 400$ square miles in the low district north of the Ozark uplift. The lower 20 miles of the course of the river is in the Mississippi River bottoms. The drainage basin is decidedly level, and there is only a slight fall in the river from its source to the mouth. The flow is very unsteady, the range in height at Murphysboro during the year covered by this report being 31 feet.

Samples.-Daily samples of water were collected from the intake at the waterworks at Murphysboro by Mr. H. C. Stagner, chief engineer. A gage was placed on the river in November, 1906, and readings were taken at the time of the collection of the samples.

Quality of water.-Analyses of the composite samples from the Muddy are given in Table 37, together with averages for the year and gage readings. The percentage composition of the dry residue is given in Table 17 (p. 53).

The water of Muddy River is the most variable in character of all those examined for this report. This may be due, in some measure, to the different characteristics of the tributaries, but it is probably due more to contamination by mine drainage, the variations being very much the same as those noted by M. O. Leighton, ${ }^{a}$ of the United States Geological Survey, in his careful study of the influence of mine drainage on Susquehanna River in Pennsylvania. Fron the low value of the bicarbonate occurring at certain times with very high values for the sulphates, it is probable that at times the water'from the Muddy is actually acid. If the water were acid for one or two days out of the ten on which the daily samples were collected to make a given composite, the composite sample might easily be slightly alkaline.

Like the other streams in the southern part of the State, Muddy River carries a large amount of very fine suspended matter. Much of this material, which seems to be really suspended matter and not color, can not be held by any ordinary method of filtration, but by the use of a coagulant the water may be rendered porfectly clear and almost colorless. This finely divided suspended matter accounts, in part, for the fact that the values for silica in Muddy River are very high. In nearly every sample where the silica wos high there was left after treatment with hydrofluoric acid a residue, amounting to 1 to 5 parts per million, which was insoluble in hydrochloric acid and not volatilized by hydrofluoric acid. Several of tlese residues were analyzed by fusing them with acid sodium sulphs,te and making a complete analysis of the fused mass. The precipitate with ammonia, that is, the iron and aluminum, on ignition weighed in every case

a Quality of water in the Susquehanna River drainage basin: Water-Supply Paper U. S. Geol. Survey No. 108, 1904. 
almost exactly the same as the original silica residue. The iron in this insoluble residue was usually a very small proportion of the whole. This would indicate that the finely divided matter is an aluminum silicate.

In analyzing similar waters at the Washington laboratory, alumina cream was used for clarifying the samples and removed the suspended matter without affecting the silica dissolved in the water. A number of experiments were made to compare the effect of the treatment using alumina cream with that of the Berkefeld filter, and the filtrates from the two treatments were found to give the same results on analysis. It was found necessary in these experiments to use alumina cream in clarifying the sample on which the determination of bicarbonates was made. If this method of analysis had been adopted on all rivers of southern Illinois, the results would have been more uniform and would have represented more accurately the material dissolved in the water. They would also have shown the kind of water that would have been obtained by the use of $s$ mechanical filtration plant.

Municipal supplies.-In the section of Illinois drained by Muddy River there is no large supply of satisfactory underground water. According to analyses ${ }^{a}$ by the Illinois State Water Survey, water from the municipal supply at Carbondale, which is obtained from deep wells, contained at different times from 1,200 to 2,400 parts per million of dissolved matter, about three-fourths of which was common salt. In addition, there are enough salts of magnesium and calcium to make the water about as hard as that of the Muddy. This, of course, makes it undesirable for domestic use. With such water in the wells the only chance for a sufficient municipal supply lies in the use of a river water, even though its quality is much inferior to that of most of the rivers of northern Illinois, where well waters are used almost exclusively.

Water such as that of Muddy River can be purified only by careful treatment with some coagulant and proper filtration. For much of the year water from the Muddy can be clarified only by the use of aluminum sulphate with lime, but the amount of lime required will vary greatly from day to day. In softening the water for use in steam boilers or in laundries, the proper amounts of chemicals to be added can be determined only by tests on each lot of water treated.

\section{MISSISSIPPI RIVER.}

Municipal supplies.-Mississippi River forms the western boundary for the whole State of Illinois. The cities of Moline, Rock Island, Quincy, Alton, East St. Louis, and Cairo, located on the river, are important manufacturing centers. The first five of those and two

$a$ Bartow, Edward, Municipal water supplies of Illinois: Bull. Univ. Illinois, October 21, 1907. 
smaller cities obtain water from the river for municipal supply. In this way about 125,000 persons use the river water. On the opposite bank in Iowa and Missouri are more cities that use the river water and serve many more consumers. The magnitude of the whole river as compared with the stretch flowing past Illinois makes it necessary in this report to discuss merely the quality of the vater in the part of the river bounding the State. The river as a whole is discussed in a paper by R. B. Dole. ${ }^{a}$

At the cities where the river furnishes the supply of water for domestic use some method of purification is used. Much of the suspended matter is removed by sedimentation in storage basins, and commonly a coagulant is used with filtration.

Samples.-Daily samples were collected at Quincy and Chester for a year, beginning August 1, 1905, and at Moline for half a year, beginning February 1, 1907 . Collections were made by the superintendents of the waterworks, Mr. Magnus Olsen, at Moline, and Mr. F. J. Brinkoetter, at Quincy. In both these places samples were collected from the pump taking water from the river for the filter beds. At the southern Illinois penitentiary, at Chester, Mississippi River water is pumped from the river to a small reservoir and thence distributed through the grounds. Through the kindness of the warden, Mr. James B. Smith, samples were collected each day from the intake pump.

Quality of water.-Analyses of composite samples, made up of ten daily samples for each of these stations, are given in Tables 38, 39, and 40. As would be expected, the suspended matter and dissolved matter both increase in amount as one goes down the river. The percentage composition of dry residue from the filterad water is given in Table 11.

TABLE 11 -Percentage composition of dry residue of fltered Mississippi River water.

\begin{tabular}{|c|c|c|c|c|c|}
\hline & \multicolumn{3}{|c|}{ February 1 to July $31,1 \subseteq 07$. } & \multicolumn{2}{|c|}{$\begin{array}{l}\text { August 1, 1906, to } \\
\text { July } 31,1907 .\end{array}$} \\
\hline & Moline. & Quincy. & Chester. & Quincy. & Chester. \\
\hline 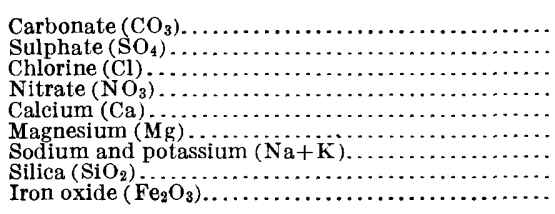 & $\begin{array}{r}42.3 \\
13.6 \\
2.1 \\
1.0 \\
18.7 \\
7.3 \\
5.7 \\
9.0 \\
.3\end{array}$ & $\begin{array}{r}42.9 \\
12.9 \\
1.9 \\
1.2 \\
19.1 \\
7.7 \\
5.2 \\
8.8 \\
.3\end{array}$ & $\begin{array}{r}32.1 \\
22.7 \\
3.3 \\
1.4 \\
17.6 \\
6.3 \\
7.8 \\
8.6 \\
.2\end{array}$ & $\begin{array}{r}43.2 \\
12.6 \\
2.2 \\
1.1 \\
18.1 \\
8.0 \\
5.5 \\
9.0 \\
.3\end{array}$ & $\begin{array}{r}33.2 \\
21.8 \\
3.8 \\
1.0 \\
17.1 \\
6.2 \\
8.2 \\
8.5 \\
.2\end{array}$ \\
\hline 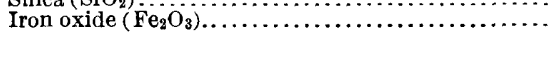 & 100.0 & 100.0 & 100.0 & 100.0 & 100.0 \\
\hline Salinity, parts per million. & 177 & 194 & 256 & 199 & 258 \\
\hline
\end{tabular}

a The quality of surface waters in Mississippi River basin: Proc. Illinois Water-Supply Assoc., 1910. 
As the samples at Moline were collected during six months only, the average at Quincy and Chester has been calculated for this period, and the percentage composition is given for the six months as well as for the whole year.

The percentage composition does not change much between Moline and Quincy. The only tributaries of any considerable size entering the river between these points are Des Moines and Rock rivers. The water of Des Moines River does not differ very much in quality from that of the Mississippi at Moline, though it contains a somowhat larger amount of dissolved solids and a somewhat smaller proportion of magnesium. Rock River carries about the same amount of dissolved solids as Des Moines River, but the proportion of magnesium is very much higher than in either the Des Moines or the Mississippi at Moline.

Between Quincy and Chester the main tributaries are Illinois and Missouri rivers. Illinois River water is not very different from that of the Mississippi at Quincy, though it probably contains a smaller amount of dissolved material, a larger amount of chlorine, and a somewhat higher percentage of magnesium. But the water of Missouri River is very different from that of Mississippi River at Quincy or that of Illinois River at its mouth. Missouri River cerries a very much larger amount of dissolved material which contains a much higher percentage of sulphate and a correspondingly lower percentage of carbonate. It has a somewhat higher proportion of chlorine. The sodium is decidedly higher, while the magnesium is lower and the calcium slightly lower than at Quincy. As the flow of the river at Chester is on the average about one-half Missouri River water and the other half upper Mississippi and Illinois River water, these characteristics of Missouri River water make themselves felt in the character of the Mississippi water at Chester.

Variations at Quincy.-Discharges of Mississippi River at Quincy have been calculated by using Weather Bureau gage readings at Hannibal, Mo., together with a rating table prepared by Herman Stabler from various discharge measurements by the U. S. Engineer Corps and the United States Geological Survey. In Table 12 are given the discharges at Hannibal, the dissolved solids at Quincy, and the discharge of dissolved material in tons per twenty-four hours calculated from these figures. The average variation in discharge was 32 per cent of the mean value; the average variation in dissolved solids was 8.6 per cent of the mean value, and the average variation in amount of dissolved solids per day was 30 per cent of the mean value. The fact that the amount of solids per day does not vary as much as the discharge is due to the fact that in times of high discharge the proportion of dissolved solids is usually lower than in times of low discharge. 
TABLE 12.-Dissolved solids in Mississippi River at Quincy.

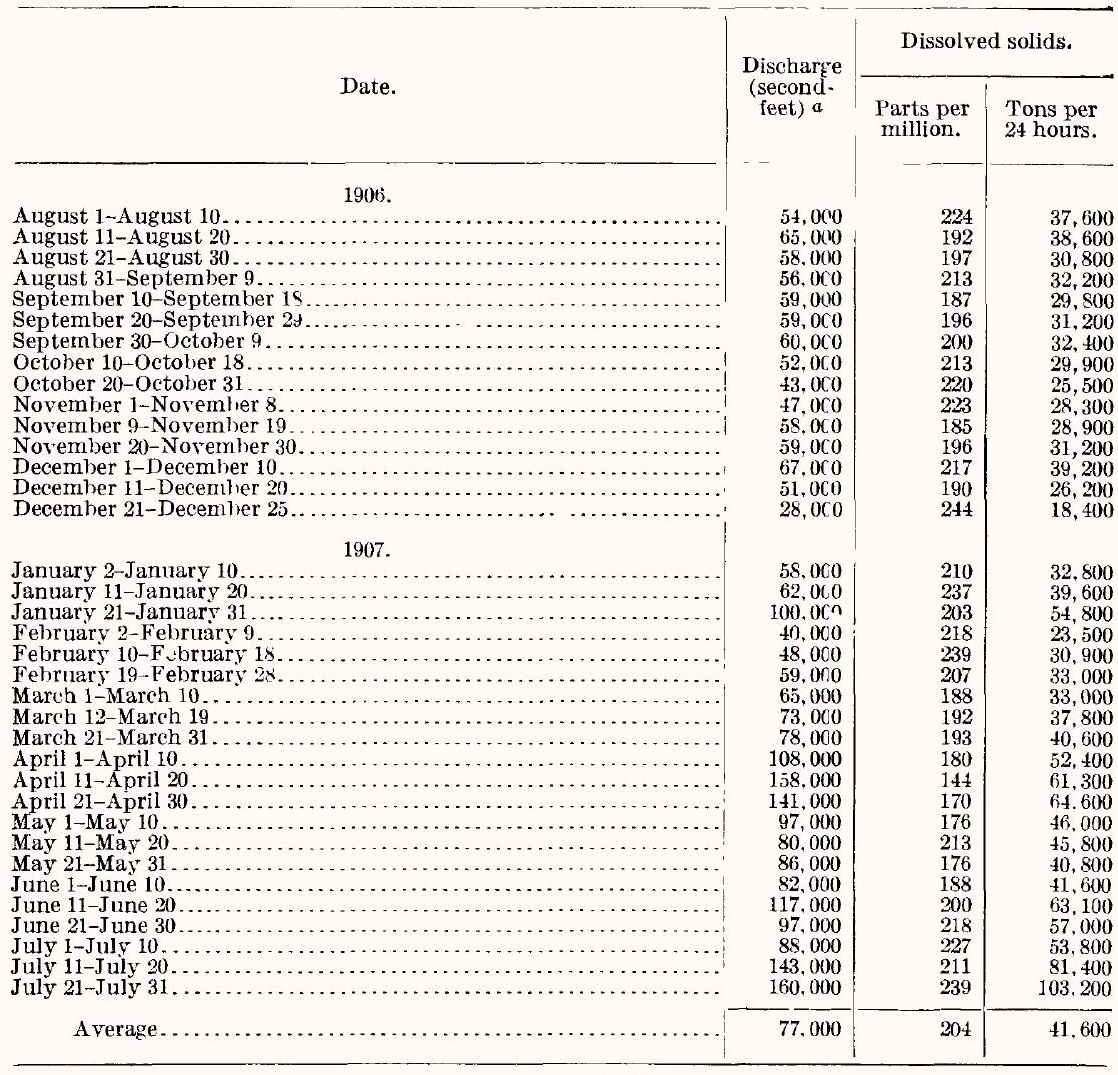

$a$ At Hannibal, Mo.

In studying the analyses at Quincy and Moline, together with analyses made in the Iowa City laboratory of the Survey ${ }^{a}$ on samples of water from Minnesota River at Shakopee and Des Moines River at Keosauqua, it is seen that there is an increase in dissolved solids at Quincy and Moline in the latter part of June and July, at a time of high flow. Minnesota River has a drainage area of about 16,000 square miles, between one-fifth and one-sixth the drainage area of Mississippi River at Moline. The rise in the Mississippi at Moline and Quincy in June and July, 1907, was to a considerable extent due to high water from the Minnesota. As the average value for dissolved solids of the Minnesota during this period was over 400 parts per million, this fact would account for the increase in these solids at Moline and Quincy concordantly with the increase in the discharge.

$a$ Dole, R. B., Quality of surface water of the United States, pt. 1: Water-Supply Paper U. S. Geol. Survey No. 236, 1909. 
Variations at Chester.-Discharges of Mississippi River at Chester have been assumed to be equal to the discharge at St. Louis. It is probable that the discharge at Chester is from 1 to 3 per cent higher than at St. Louis, but no rating table was easily obtainable for the river at Chester, whereas a fairly satisfactory rating table was obtained for St. Louis. From the Weather Bureau gage readings and a rating table which was prepared by Stabler, discharge measurements were calculated for the river at St. Louis for each ten-day period covered by the analyses. In Table 13 these figures are given, together with the dissolved solids in parts per million and the amount of dissolved solids carried by thè river at Chester.

Table 13.-Dissolved solids in Mississippi River at Chester.

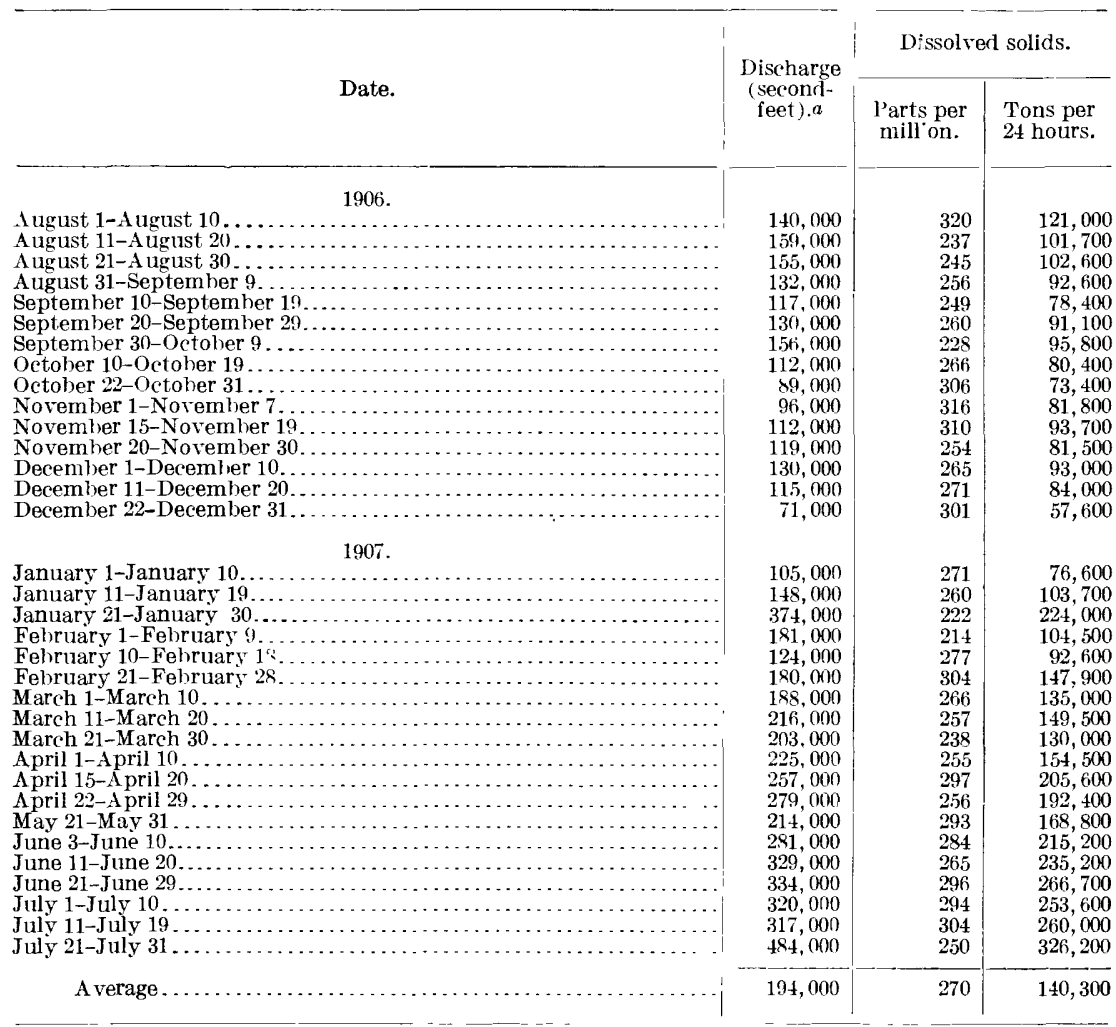

a At St. Louis.

The average variation in discharge of the Mississippi at Chester is 40 per cent of the mean value of the discharge; the average variation in dissolved solids is 8.5 per cent of the mean value, and the average variation in the solids carried per day is 41 per cent. It is unusual that the solids carried per day should vary more than the discharge, 
for this would indicate that in times of high water there was more material dissolved in the river than in times of low water. In order to see if this could be accounted for, calculations were made as to the amount of dissolved material carried by each of the three component streams making up the Mississippi at Chester. For this purpose monthly average gage heights and discharge measurements were computed by Mr. Stabler.

The volume of upper Mississippi water reaching Chester was assumed to be measured by discharges at Hannibal, Mo., which correspond to the analyses at Quincy, Ill. No discharge measurements are available for the Illinois below Peoria, and as the drainage area of Illinois River at its mouth is very much greater than at Peoria, the proportional effect of Illinois River would not be at all accurately represented by taking discharges at Peoria. Estimates by Cooley, ${ }^{a}$ however, indicate that the discharge of the Illinois into the Mississippi is probably about 1.75 times the discharge at Peoria, and therefore in the calculations 1.75 times the discharge at Peoria was used as representing the amount of Illinois water reaching Chester, while the analyses at Kampsville were used as representing its quality. The amount of Missouri River water reaching Chester was represented by the discharge measurements at St. Charles, Mo. In Table 14 are given these discharges for each month, together with the sum of the three discharges and the discharges as calculated for Mississippi River at St. Louis. It will be seen that in geners l the sum of the three discharges is somewhat greater than the estimated discharge of the Mississippi at St. Louis. It is not likely, however, that the proportional error is very serious.

TABLE 14.-Discharges of Mississippi, Illinois, and Missouri rivers at points stated.

[In thousands of second-feet.]

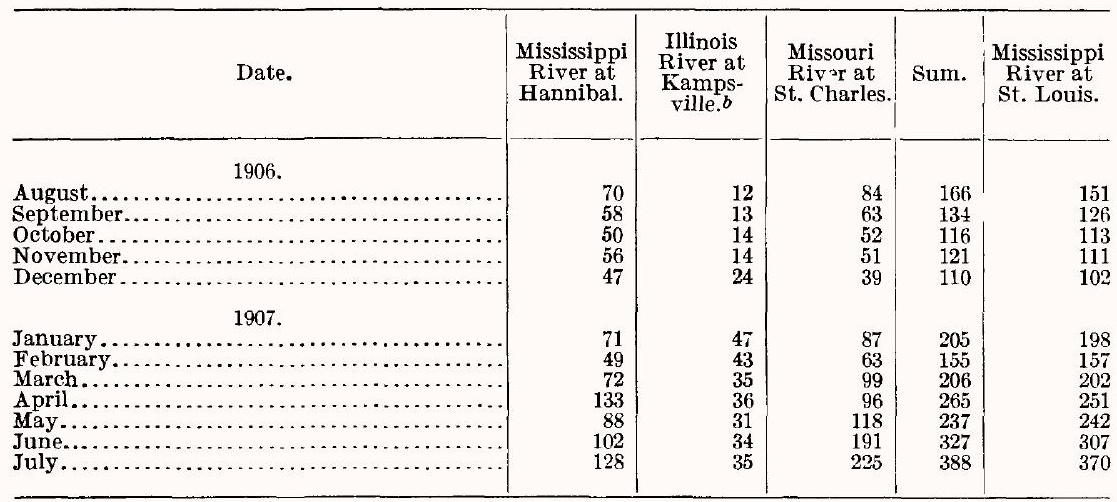

a Cooley, L. E., The Illinois River basin in its relation to sanitary engineering, Illinois State Board of Health, 1889.

$b 1.75$ times the discharge at Peoria. 
In Table 15 is given the percentage of the discharge at Chester which is furnished by each river; the average value for the dissolved solids in these rivers; one one-hundredth of the product of these two figures, which shows the contribution of each river to the dissolved solids in Mississippi River at Chester; the sums of these three components; and the value for dissolved solids at Chester as obtained by averaging the values for the three composite samples of each month. The figure for May is of almost no value, as samples were not received during the first twenty days of that month and only one analysis was made during the month.

It is evident that this method of calculating the dissolved solids in Mississippi River water at Chester does not give the ccrrect result, the value being higher than those found. This would indicate a possible lack of complete mixing of Missouri River with Mississippi River at the point where the samples were collected. Another explanation would be the undue influence of Kaskaskia Piver, which enters a short distance above Chester. The drainage area of Kaskaskia River is not over 3,000 miles, so that its contribition to the flow of the Mississippi is almost negligible. If, however, its water is not thoroughly mixed with the other water coming down the Mississippi, the samples collected at Chester might have too large a proportion of Kaskaskia River water. In order to determino this point, curves were plotted showing (1) dissolved solids calculated from the analyses and discharges of upper Mississippi, Illinois, and Missouri rivers; (2) dissolved solids as found by analysis at Chester; (3) dissolved solids as found in the Kaskaskia at Carlyle. It appears from inspection of these curves that the dissolved solids found at Chester follow very closely the dissolved solids as calculated. The variations from the curve of calculated values are the same as the variations in the values for the dissolved solids in the Kaskaskia. The greatest difference between the calculated and determinod values is only about 8 per cent of the former. Inspection of 'Tak'e 15 shows that in the latter part of the year Missouri River furnished a very large proportion of the flow at Chester. The dissolved solids from Missouri River are very much higher than the average value for dissolved solids in Mississippi River. This then would cause an increase in dissolved solids in Mississippi River at the same time that the discharge increased. Thus when the discharge is doubled the amount of dissolved matter carried by the stream is more than doubled, as the water contains in each cubic foot much. more than the average amount of dissolved matter. 
TABLE 15.-Composition of and average solids in Mississippi River at Chester.

\begin{tabular}{|c|c|c|c|c|c|c|}
\hline \multirow[b]{2}{*}{ Date. } & \multicolumn{3}{|c|}{ Percentage of discharge at Chester. } & \multicolumn{3}{|c|}{ Dissolved solids (parts per million). } \\
\hline & $\begin{array}{c}\text { Mississippi } \\
\text { River at } \\
\text { Hannibal. } \\
\text { (a) }\end{array}$ & $\begin{array}{l}\text { Tllinois } \\
\text { River at } \\
\text { Kamps- } \\
\text { ville. } \\
\text { (b) }\end{array}$ & $\begin{array}{c}\text { Missouri } \\
\text { River at } \\
\text { St. Charles. } \\
\text { (c) }\end{array}$ & $\begin{array}{c}\text { Mississippi } \\
\text { River at } \\
\text { Quincy. } \\
\text { (d) }\end{array}$ & $\begin{array}{l}\text { Illinois } \\
\text { River at } \\
\text { Kamps- } \\
\text { ville. } \\
\text { (e) }\end{array}$ & $\begin{array}{c}\text { Missouri } \\
\text { River at } \\
\text { Ruegg, Mo. } \\
\text { (f) }\end{array}$ \\
\hline 1906. & & & & & & \\
\hline August..... & 42.2 & 7.2 & 50.6 & 204 & 263 & \\
\hline September. & 43.3 & 9.7 & 47.0 & 199 & 236 & \\
\hline October... & 43.1 & 12.1 & 44.8 & 211 & 297 & 375 \\
\hline November.. & 46.3 & 11.6 & 42.1 & 20 & 263 & 429 \\
\hline December... & 42.7 & 21.8 & 35.5 & 217 & 301 & 403 \\
\hline January 1907. & & & & & & \\
\hline $\begin{array}{l}\text { January............. } \\
\text { February ........ }\end{array}$ & $\begin{array}{l}34.6 \\
31.6\end{array}$ & $\begin{array}{l}22.9 \\
27.8\end{array}$ & $\begin{array}{l}42.5 \\
40.6\end{array}$ & 22 & $\begin{array}{l}247 \\
206\end{array}$ & $\begin{array}{l}325 \\
337\end{array}$ \\
\hline March..... & 35.0 & 17.9 & 48.0 & $19^{\circ}$ & 232 & 317 \\
\hline April..... & 50.2 & 13.6 & 36.2 & 165 & 286 & 370 \\
\hline May...... & 37.1 & 13.1 & 49.8 & 18 & 289 & 311 \\
\hline June.......... & 31.2 & 10.4 & 58.4 & 203 & 288 & 338 \\
\hline July...$\ldots \ldots \ldots \ldots \ldots \ldots \ldots$ & 33.0 & 9.0 & 58.0 & 233 & 261 & 307 \\
\hline
\end{tabular}

\begin{tabular}{|c|c|c|c|c|c|c|}
\hline \multirow{4}{*}{ Date. } & \multicolumn{6}{|c|}{ Dissolved solids (parts per million). } \\
\hline & \multicolumn{5}{|c|}{ Mississippi River at Chester. } & \multirow{3}{*}{$\begin{array}{c}\text { Kaskaskia } \\
\text { River at } \\
\text { Carlyle. }\end{array}$} \\
\hline & \multicolumn{4}{|c|}{ Caleulated. } & \multirow[b]{2}{*}{$\begin{array}{l}\text { By analy- } \\
\text { sis. }\end{array}$} & \\
\hline & $\begin{array}{l}\text { Upper } \\
\text { Mississippi } \\
\text { River } \\
\text { water. } \\
\left(\frac{a \times d}{100}\right) \\
\text { (g) }\end{array}$ & $\begin{array}{c}\text { Illinois } \\
\text { River } \\
\text { water. } \\
\left(\frac{\mathrm{b} \times \mathrm{e}}{100}\right) \\
\text { (h) }\end{array}$ & $\begin{array}{c}\text { Missouri } \\
\text { River } \\
\text { water. } \\
\left(\frac{\mathrm{c} \times \mathrm{f}}{100}\right) \\
(\mathrm{i})\end{array}$ & $\underset{(g+h+i}{\text { Sum. }}$ & & \\
\hline 1906 . & & & & & & \\
\hline August............. & 86.0 & 18.9 & & & 267 & 237 \\
\hline October..... & $\begin{array}{l}86.1 \\
90.8\end{array}$ & $\begin{array}{l}22.9 \\
35.9\end{array}$ & $\ddot{168}$ & $2 n$ & $\frac{255}{267}$ & $\begin{array}{l}261 \\
223\end{array}$ \\
\hline November.. & 93.0 & 30.5 & 181 & 304 & 293 & 245 \\
\hline December.. & 92.7 & 65.6 & 144 & 302 & 279 & $25 \mathrm{t}$ \\
\hline 1907. & & & & & & \\
\hline January.......... & 75.0 & 56.5 & 138 & 270 & 251 & 191 \\
\hline February ......... & 69.8 & 57.2 & 137 & 264 & 265 & 259 \\
\hline March........... & 66.8 & 39.4 & 152 & 258 & 254 & 235 \\
\hline April............. & 82.8 & 38.9 & 134 & 256 & 269 & 280 \\
\hline May.............. & 69.7 & 37.8 & 155 & 262 & $(293)$ & 264 \\
\hline June........... & 63.0 & 30.0 & 198 & 200 & 282 & 221 \\
\hline July ......... & 77.8 & 23,5 & 178 & 279 & 283 & 264 \\
\hline
\end{tabular}

It is evident from inspection of the tables that Mississippi River above the Missouri is not remarkably turbid as compared with other streams of the Middle West. Its turbidity averages about the same as that of other rivers in Illinois. At Chester the turbidity resembles that of the Missouri. Usually the suspended matter causing this turbidity is composed of fairly large particles which quickly settle so that the water can be clarified easily by mere sedimentation. At times, however, the turbidity is caused by material so fine that it is exceedingly difficult to filter. This excess can be recognized in the analyses by the high values for silica. It is probable that in most 
samples where the value for silica is over 25 parts per million, the excess over this figure is due to suspended matter which was not removed by filtration. On account of the large proportion of sulphate in Missouri River water, Mississippi River water below the mouth of the Missouri is much less satisfactory for industrial purposes, even after purification. Above the Missouri, Mississippi River water is of much the same quality as most ground and stream waters throughout Illinois.

WABASH RIVER SYSTEM.

The drainage basin of Wabash River has an area of over 33,000 square miles. It extends westward from western Ohio across the central portion of Indiana and southward to Ohio River. It embraces on its west side a considerable portion of southeastern Illinois. Drainage from Illinois into Wabash River is carried by Vermilion, Embarrass, and Little Wabash rivers. Bonpas River drains a small area between Embarrass and Little Wabash rivers.

WABASH RIVER.

Municipal supplies.- - The Wabash forms the boundary of the State on the east and south for a distance of nearly 200 miles by river. Its water is usually rather turbid and probably contain more dissolved mineral matter than well waters which may be obtained along its banks. For these reasons it is not likely to be used as a source of supply, except for communities too large to find a sufficient quantity in wells. There are not many large cities in Illinois directly on the river. Grayville and Mount Carmel, however, obtain their water supplies directly from it.

\section{VERMILION RIVER, $a$}

Drainage.-Vermilion River drains an area of about 1,500 square miles in northern Illinois. The river rises in the Eloomington morainic system at the reentrant angle in Ford and Livingston counties, only a few miles from the source of the other river of the same name, which flows northward to the Illinois. From its source Vermilion River flows east and southeast, entering the Wabash in Indiana. In the last 10 miles of its course it receives very little drainage, except from the immediate vicinity of the stream. Its flow is not very rapid and the discharge is somewhat irregular.

Municipal supplies.-The municipal supply of Danville, Ill., is obtained from North Fork of Vermilion River and is purified by filtration after the use of a coagulant.

Samples.-The samples of raw river water were collected by $\mathrm{Mr}$. William Van Steenberg, engineer of the Danville Water Company. 
Quatity of water.-Analyses of the composite ssmples from Danville are given in Table 41, together with the average for the year.

The water of Vermilion River at Danville is very much like that obtained from other rivers draining the part of Illinois covered by glacial drift. The variations in dissolved solids from time to time are not very great. The average variation for the year was 8.4 per cent of the mean value for the dissolved solids. The percentage composition of the water does not vary much with variations in the amount of dissolved solids. The suspended matter is usually of such character that it can be easily removed by filtration. Analyses of ground water from drift along the course of Vermilion River show that for most industrial purposes there is not much choice between the water from the river and that from wells.

EMBARRASS RIVER.

Drainage.-Embarrass River drains an area of about 2,000 square miles in eastern Illinois. Its source is in the Champaign morainic system, immediately south of Champaign, and it flows a little east of south until it enters Wabash River about 6 miles below Vincennes. The flow is very variable. It is said that at times the river goes almost dry at Lawrenceville, 8 miles above its mouth.

Municipal supplies.-The cities of Charleston, Greenup, and Newton obtain their water supply from the Embarrass. At none of these places is the water purified.

Samples.-Daily samples were collected for the year at Charleston and at Lawrenceville. At Charleston the samples were obtained from the pump taking water directly from the river for municipal supply. The intake at the punping station is about 240 feet south of the pump, near the middle of the river. Collections were made by Mr. James Winkleblack and Mr. Louis Strodbeck, engineers at the waterworks.

At Lawrenceville samples were collected for part of the year by Mr. C. H. Arnold, superintendent of the Lawrenceville Water Company. The supply for the city is obtained from deep wells, and the samples furnished by Mr. Arnold were obtained by dipping the water from the river near the waterworks. For a time the collection of samples at Lawrenceville was omitted, owing to a change in the superintendent of the waterworks, but after Octol $? \mathbf{r}$ 12, 1906, samples were collected by Mr. Perry Barmhouse at the pumping station of the Big Four Railway from the pump which takes water direct from the river.

Quality of water.-Analyses made on the composite samples from Charleston and Lawrenceville are given in Tables 42 and 43 . The percentage composition of the dry residue from the filtered water at these two stations is given in Table 16. 
TABLE 16.-Percentage composition of dry residue from filtered Embarrass Ricer water.

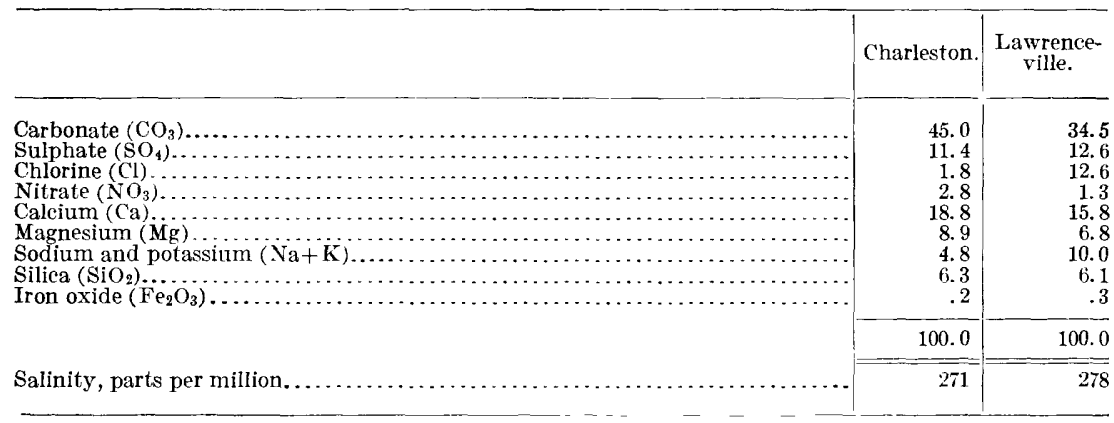

The water of Embarrass River at Charleston is very much like all the river waters in the section of Illinois covered by the glacial drift. On account of the fact that the drainage basin above Charleston is somewhat thinly populated, the proportion of sodium and chlorine is lower than in most of the streams of the State. It is probable that the character of the water remains fairly constant through its course down to a point a short distance above Lawrenceville.

The water from the river at Lawrenceville is entirely different from that at Charleston, the change consisting almost wholly of a large increase in sodium and chlorine. Table 43 shows that its percentage composition also varies very much throughout the year. This may be due in large measure to the effect of the water draining from oil wells above Lawrenceville. The beginning of the great activity in the oil industry in southern Illinois occurred during the time covered by these analyses. If the river continues to receive waste waters from the oil wells it will be of very little value as a source of supply either for municipal use or for manufacturing.

\section{LITTLE WABASH RIVER.}

Drainage.-Little Wabash River drains 3,000 square miles in southeastern Illinois, entering the Wabash 8 miles in a direct line from the latter's junction with the Ohio. From its source in the Shelbyville morainic system, in southwestern Coles County, it flows slightly west of south for 50 miles and then east of south to its mouth, a distance in a direct line of about 75 miles. Its largest tributary is Skillet Fork, which has a drainage area of about 1,000 square miles and a length in a straight line of about 65 miles; it enters the Little Wabash from the west just above Carmi.

Municipal supplies.-The cities of Effingham and Carmi are supplied with water from the Little Wabash. No analyses were made of the water at Effingham, but an analysis by the Illinois state Water 
Survey ${ }^{a}$ indicates that it resembles the river waters of northern Illi nois. The water at Carmi is pumped from the river to a standpipe from which it is distributed through the mains.

Samples.-Samples were collected from the river at Carmi by $\mathrm{Mr}$ Samuel Morgan, engineer of the waterworks.

Quality of water.-Analyses of the composite samples from Carm are given in Table 44 . The percentage composition of the dry residu is given in Table 17.

The quality of water at Carmi is exceedingly variable, probabl: owing in some measure to the influence of Skillet Fork, the drainag basin of which is typical of southern Illinois. The average variatic in dissolved solids at Carmi is 17 per cent of the mean value, and th range from maximum to minimum is 73 per cent of the mean value.

During the greater part of the time water from Little Wabas' contains a large amount of finely divided material which can not $b$ removed by any simple filtration. On account of the small amount of calcium and magnesium in the water it is very satisfactory fo use in steam boilers or for any other purpose where the turbidity an iron do not cause inconvenience.

\section{CACHE RIVER.}

Drainage.-Although Ohio River once discharger wholly or in par through the Cache Valley, the region now drained by Cache Rive has an area of only about 600 square miles, comprining the great par of the State south of the Ozark ridge. There are extensive swamp in the drainage basin of Cache River, but it is novertheless subjec to floods of considerable magnitude.

Samples.-Daily samples were collected and daily gage height read by Mr. J. F. Anderson at the Illinois Central pumping static where the railroad crosses the river below Mounds.

Quality of water.-Analyses of the composite samples from Mound are given in Table $45 . \quad$ In Table 17 is given the porcentage composi tion of an average analysis for each of the three rivers draining th southern part of the State. Although the Muddy differs from th other two more than they do from each other, still the similarity o the three waters is evident from a study of the porcentage composi tion. They all contain a much larger percentage of sodium salts tha' the rivers of northern Illinois. The proportion of magnesium $t$ calcium is very much less than in the northern rivers. The Mudd? contains more sulphate than carbonate on account of the min drainage referred to on page 40 . The proportion of silica in thes streams is much larger than that in the northern rivers. Part of thi silica is not actually in solution in the water but is in the finel. divided suspended matter which was not removed. In the sum of th

a Bartow, Edward, Municipal water supplies of Illinois: Bull. Univ. Illinois, October 21, 1907. 
radicles, which is given in Table 17 as salinity, no account is taken of the material insoluble in hydrochloric acid and not volatilized by hydrofluoric acid, although this amounted in many samples to as much as five parts per million. On this account the salinity is noticeably lower than the values obtained for the dissolved solids.

With the exception of the waters of some reservoirs or ponds, certain shallow wells, and Lake Michigan, these river waters are the softest in the State and are thus excellent for use in steam boilers. The large amount of iron, which can not be removed without a coagulant, makes the waters unsatisfactory for laundry us?.

TABLE 17.-Percentage composition of dry residue from filtered river water in southern Ilitinois.

\begin{tabular}{|c|c|c|c|}
\hline & $\begin{array}{l}\text { Muddy } \\
\text { River at } \\
\text { Murphys- } \\
\text { boro. }\end{array}$ & $\begin{array}{c}\text { Little } \\
\text { Wabash } \\
\text { River at } \\
\text { Carmi. }\end{array}$ & $\begin{array}{l}\text { Cache } \\
\text { River at } \\
\text { Mounds. }\end{array}$ \\
\hline 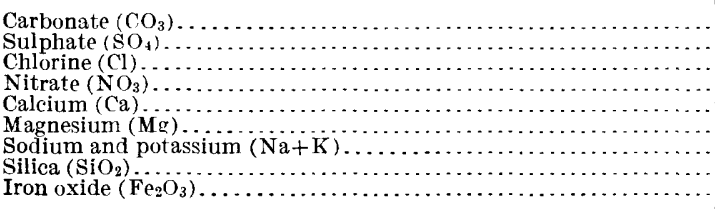 & $\begin{array}{r}17.1 \\
35.0 \\
6.2 \\
1.0 \\
12.2 \\
5.6 \\
9.9 \\
11.5 \\
1.5\end{array}$ & $\begin{array}{r}27.5 \\
20.3 \\
4.7 \\
1.3 \\
12.6 \\
5.8 \\
9.5 \\
16.5 \\
1.8\end{array}$ & $\begin{array}{r}31.1 \\
14.0 \\
5.0 \\
1.5 \\
14.0 \\
4.4 \\
11.1 \\
16.2 \\
2.7\end{array}$ \\
\hline & 100.0 & $1 c 0.0$ & 100.0 \\
\hline Salinity, parts per million. & 206 & 158 & 136 \\
\hline
\end{tabular}

OHIO RIVER.

Ohio River is used as a source of supply by the cities of Golconda and Metropolis, and at one time furnished part of the municipal supply of Cairo. No analyses were made in Illinois of water from Ohio River, as it has been extensively studied at a number of places, especially Cincinnati and Louisville, where it is used as a source of city supply. It is the usual turbid, hard water of a stream entering the Mississippi from the east. Where well water can be obteined along its shores, it is usually much better than the river water, so that the only use for the river water is in cities too large to be supplied by wells.

\section{MUNICIPAL SUPPLIES.}

It is usually believed that any community with a population of over 1,000 should have a common water supply. Mary cities in Illinois with less than 1,000 inhabitants have municipal supplies, while only a few with more are without one, and most of these are considering the question of installing a waterworks system.

\section{WELLS.}

For individual supplies wells have long been the most satisfactory source. In Illinois these may be shallow wells 15 to 30 feet deep, 
wells in drift 70 to 150 feet deep, or wells in rock 500 to 2,000 feet deep. Probably the number of supplies from shallow wells is greater than that of all other kinds put together. The rumber of persons served by such wells is, however, not over half the population of the State, for very few large supplies are obtained from this source.

Over a great part of the State wells 70 to 150 feet deep furnish an abundant supply of water. In many places this water is of such a nature that on exposure to the air it becomes turbid and furnishes opportunity for the growth of microscopic organisms which give unpleasant tastes or odors to the water. 'Tre city supplies at Champaign and Bloomington are of this type. Water from shallow wells is subject to pollution, and in any fairly densely populated community almost certain to be unsafe for drinking, but wells deer in the drift give a water that is perfectly safe.

A number of individuals and several cities ohtain a supply of water from deep wells in rock. At most of the cities, as Sterling, Rockford, and Elgin, this water, in addition to being perfectly safe to drink, contains less dissolved mineral matter than surface waters or shallow well waters in the same neighborhood. These deep-well waters may be drawn upon at a normal rate for a very long time without showing any loss of head, but nearly everywhere the quantity which can be obtained, even by increasing the number of wells, is decidedly limited. This has driven many cities to adopt surface water as a source of supply.

SURFACE SUPPLIES.

UNTREATED WATERS.

Almost any surface water in Illinois is sure to be polluted and dangerous to use for drinking. The largest user of surface water in the State is the city of Chicago, which is supplied by water from Lake Michigan. This water has in times past been so seriously polluted as to have a decided effect upon the death rate of the city, but within the last few years improvements have been made which render it reasonably safe. The intakes have been extender so that water is pumped from a distance of 2 to 4 miles from the shore, making it probable that the water will be free from any accidental small pollution which may reach the lake. The opening of the Chicago drainage canal removed practically all the Chicago sewage from Lake Michigan. A few cities obtain supplies from reservoirs fed by springs or smal streams with an uninhabited drainage basin, and these supplies, with careful supervision, may be kept free from contamination.

PURIFICATION.

By far the greater number of Mlinois cities of larye size obtain theil water supplies from surface waters which are badly polluted. Fortunately for the health of the community, most of these sources 0 . 
supply furnish a water of high turbidity, which must be removed to make the water attractive in appearance. In many places this turbidity is caused by particles of extremely small size, often of a size comparable with that of bacteria, and any process which will effectively remove them will at the same time remove the bacteria which may be dangerous. In several cities where no purification of the water is attempted, the municipal supply is not used for domestic purposes.

Sedimentation.- The simplest method of purification of a turbid water is mere sedimentation. If a number of the surface waters of Illinois are subjected to sedimentation for a few days a large proportion of the suspended matter will be removed, but for most waters of the State mere sedimentation is not likely to prove satisfactory. The suspended matter consists of particles so small that they settle very slowly, and to allow sufficient time for satisfactory sedimentation would require the building of very large storage reservoirs. The amount of land necessary for these reservoirs, together with the cost of construction, makes this method out of the question for the clarification of the water.

Sand fltration.--At a few places in Illinois purification of the water is accomplished by means of slow sand filtration. If a water is comparatively free from turbidity, slow sand filtration is a very effective method of purifying it. Ordinarily turbidity and bacteria are very effectively removed and the effluent is clear and safe for drinking. The changes in the mineral content of the water caused by filtering through a layer of sand and gravel 3 to 6 inches deep are, however, not of any consequence.

Mechanical filtration.-Illinois waters very rarely lend themselves to treatment by slow sand filtration, on account of the fineness of their suspended matter, and to meet the needs of water of tr is class the process known as mechanical filtration has been devised. In this process the water is treated with a certain amount of some chemical or chemicals which will form a large, flaky precipitate or, as it is called, coagulant. The water with this precipitate is then flowed upon a filter of coarse sand, through which it filters very rapidly, giving an effluent perfectly clear and fairly free from bacteria. In this process the filters soon become clogged with the precipitate which holds the bacteria and suspended matter of the water. Therefore after running a short time the supply of water is shut off and clear filtered water is forced back through the sand to wash away the film of precipitate from the top. This process wastes some of the pure filtered water. One disadvantage of this form of treatment is thet it requires much more expert attention than a slow sand filter. Another disadvantage is that, as sometimes operated, the effluent from a mechanical filtration plant is much less satisfactory than the untreated water for many industrial uses. 
Some of the early mechanical filtration plants accomplished the removal of silt and bacteria by the addition of no chemical except aluminum sulphate, which, reacting with the calcium and magnesium bicarbonates of the water, would give a precipitate of aluminum hydroxide. This precipitate is the best coagulant lnown. It carries down with itself all the finely divided suspended matter, much of the color of the water, and a very large proportion of the bacteria.

With a water deficient in bicarbonates, it is sorretimes difficult to obtain a satisfactory precipitate by the addition of aluminum sulphate alone. In the early days of mechanical filtration about the only directions furnished by those who erected the plants were that when the water was clear a small amount of alum should be added and that when the water became turbid a larger amount should be used. At the time when analyses were being made for this report difficulty was experienced at the Kankakee waterworks in obtaining satisfactory clarification for the water, which was at a very high stage. ${ }^{a}$ Aluminum sulphate was being added to the water at the rate of about 14 grains to the gallon. From analyses of the composite samples from Kankakee River at this time, however, it was evident that all the bicarbonates in one gallon of water would combine with only about 2 grains of alum, leaving for the consumers the other 12 grains which was being added to the water. Thus the aluminum sulphate was being wasted, the water was rendered less valuable to the consumers, and it was not clarified in a satisfactory manner. At present the Kankakee River water is being treated before filtration with lime and sulphate of iron in such proportions as to improve the character of the water for industrial purposes, and at the sarre time to make it clear and safe for drinking.

Softening.-For a number of years the Mississippi water at Quincy has been treated with lime and sulphate of iron in such proportions as materially to decrease its hardness. If the water is thus softened the amount of scale-forming materials will be so much decreased that with care in operation there will be much less scale formed than with the untreated water. In some studies which have hen made by the Illinois State Water Survey ${ }^{b}$ it has been pointed out that the cost of partial softening is in many cases a very small proportion of the cost of softening to the greatest possible extent; and it is probable that with proper management most of the surface waters of Illinois that are used for municipal supply could be softened to such an extent as to increase their value materially without adding very much tc their cost. No municipality in Illinois attempts to remove the

$a \mathrm{Mr}$. Cobb, superintendent of the waterworks, has described this experience in a paper read before th Illinois Society of Engineers and Surveyors. See Eng. News, vol. 59, p. 119.

$b$ Bartow, E., and Lindgren, J. M., Some reactions during water treatment: Jour. Am. Chem. Soc., vol 29, p. 1293. 
permanent hardness from water, the softening consisting merely in adding to the water more lime than is necessary to combine with the sulphate of iron or aluminum which is used to furnish the coagulant for clarification.

\section{INDUSTRIAL USES OF WATER.}

GENERAL STATEMENT.

Of the water used in Illinois, where the amount and character of the dissolved mineral matter are of great importance, by far the largest quantity is used in the production of steam porver. Many other extensive uses, however, require water of the same quality as is needed for the generation of steam; for instance, in slaughtering and preparing meat products much hot water of that grade is required. Laundry work can not be well done with a water containing a large amount of calcium or magnesium salts, or with water that is not clear and free from iron. The quality of distilled and malt liquors depends very largely on the kind of water used in the treatment of the grain. Calcium sulphate is said to have a beneficial effect, but large quantities of sodium or calcium chloride are supposed to be injurious. Of course a clear water free from organic matter is to be desired. The distilleries in Illinois generally use well water. The manufacturers of soap, candles, glucose, leather, and several minor products all require certain degrees of purity in the water used. In the manufactured iron, steel, and foundry products, on the other hand, the chief requirement in the way of water is for power. In general, the best water for industrial use is clear, soft water.

\section{LAUNDRY WATER.}

Very few river waters of Illinois are suitable for laundry work without some form of purification. Those in the northern part of the State are hard and most of those in the southern part, where some river and reservoir waters are soft enough to be used, are turbid and contain much iron. For individual family washing the problem is easily solved in all parts of the State, as the rainfall is great enough to furnish a supply of rain water at all times of the year if a cistern of sufficient capacity is constructed and the rain collected on the roof is stored in the cistern.

This method, however, is not usually possible for laundries which, in Illinois, must nearly always soften their water supply in some manner, whatever its source. To use enough soap to soften the water and then make a suds is very expensive and usually unsatisfactory. The calcium and magnesium in the water form insoluble soaps which are not easy to remove from the clothes and which make spots when the articles are ironed. Many laundries soften the water 
by the liberal use of lye and other chemicals which are applied in no very definite amounts. The most satisfactory and economical method for softening ordinary Illinois waters for laundry use is by a plant such as is used for treating boiler-feed water. Where such a plant has been properly installed and has been managed with ordimary care, the saving in soap or softening chemicals has paid for the plant in a few years, leaving the improvement in the laundering as clear gain.

\section{STEAM-BOILER WATER.}

The census of manufactures of Illinois for 1905 gives the amount of steam power used in the State for manufacturing as 651,578 horsepower. This does not include the power generated by locomotives nor a large amount of steam generated for heating.

It is not easy to figure the amount of water used in the different forms of steam production. The railway locomotive uses up the most. The less efficient types of stationary engines waste much steam and condense little to be fed to the boiler again. Steam-heating plants, on the other hand, condense their steam and retur' it to the boiler, very little fresh water being added. In manufacturing the practice varies, ranging from one extreme, where, as in a locomotive, no steam is condensed, to the other extreme, where, as in a heating plant, practically all the steam is condensed and used over again.

Troubles in a steam boiler where hard water is used are very largely dependent on the amount of fresh water put into the boiler. Many feed waters contain small amounts of carbonates or bicarbonates and large amounts of chlorine with much magnesium and cause serious corrosion of the shells and tubes of boilers. Such waters are usually best treated by the method outlined below for softening hard waters. A very few surface waters are corrosive. These are found mainly near the coal mines, where the water is made acid by the mine drainage. Unless the acidity is too great it may be corrected $h y$ the use of soda ash, but the best remedy is to avoid water that receives mine drainage.

Nearly all the waters used in Illinois for the production of steam contain large amounts of salts of calcium and magnesium, which cause much trouble in boilers, forming, unless very carefully watched, a considerable amount of scale. If a water contains enough carbonate and bicarbonate to combine with all the calcium and magnesium present, the calcium and magnesium are separated in a flocculent form when the water is fed into a boiler and heated. This material, together with the material suspended in the water, falls to the bottom of the boiler as a soft sludge and may be blown out from time to time. None of the waters that have been analyzed in the preparation of this report, however, contain enough carbonate and bicarbonate to combine with all the calcium and magnesium. As a result, when a boiler using 
any of these waters is run for some time, calcium ard sulphates accumulate to such an extent that calcium sulphate is precipitated on the shell or the tubes of the boiler. This precipitate serves as a cement and makes a hard coherent mass out of the soft sludge formed by the precipitation of the carbonates, bicarbonates, and suspended matter. This suspended matter, which is often as much as the dissolved material in the water, causes the river waters to form much more scale than would be formed by a clear water containing the same dissolved mineral matter.

\section{SOFTENING.}

At many small power plants water in steam boilers is treated with so-called boiler compounds. These compounds are many and greatly varied in character. Their most valuable constituent is soda ash; some compounds contain sugar, tannin, and various other organic substances. Very few of these compounds are any better than plain soda ash and many are worse. Their only advantege is in preventing the formation of hard scale, for, with or without their use, the salts of calcium and magnesium will accumulate in the form of sludge and must be blown out.

In a good many plants, especially in some of moderate size, the water, before reaching the boiler, is purified to a certain extent simply by heating. This causes a separation in the heater of a considerable proportion of the substances which would otherwise be separated in the boiler. This method is not a great improvement over using the water without any purification, the main difference being that the sludge has to be removed from the feed-water heater rather than from the boiler. Sometimes the water in its passage through the heater is treated with sodium carbonate or soda ash; when properly conducted this process insures the removal of practically all the calcium and magnesium, leaving nothing to go into the boiler that can form hard scale.

The best steam-boiler practice is to so soften the water that no calcium and magnesium salts can be precipitated within the boiler. To accomplish this purpose the cold water is usually treated with lime and soda ash, which are dissolved in water either saparately or together and mixed in definite proportion with the water to be treated. In ordinary water-softening practice it is customary to add a quantity of lime equivalent to the calcium and magnesium present in the water as bicarbonates, and soda ash equivalent to all the calcium and magnesium not present in the form of bicarbonates. A further quantity of lime is added equivalent to all the magnesium present, whether as bicarbonate or as some other salt. Still more lime is added to unite with the excess of carbon dioxide in the water above the amount necessary to form bicarbonates. Other factors, as 
the presence of sodium bicarbonate, iron, aluminum, and other substances, affect the amount of chemicals to be added, $k$ ut the treatment outlined above has proved satisfactory with many Illinois surface waters. If the dosing is properly done, practically all the lime and magnesium are precipitated, settling to the bottom of the tank in which the reaction is carried out. The clear water is then perfectly satisfactory for use in a boiler. It still contains enough salts of calcium and magnesium to prevent corrosion, but not enough to form any scale if the boiler is blown off reasonably often. River waters in Illinois carry so much suspended matter that it is well worth while to go to some expense to keep it out of a boiler.

In order that the different waters which have been studied for this report may be compared as to their value for the production of steam, the cost of softening has been calculated from the average analysis of the water from each station. In Table 18 are given the results of this calculation, showing the amount of lime and the amount of soda ash needed to soften 1,000 gallons of the water. The cost is figured on the basis of 0.3 cent a pound for pure lime $(\mathrm{CaO})$ and 1.2 cents a pound for pure sodium carbonate $\left(\mathrm{Na}_{2} \mathrm{CO}_{3}\right)$. Commercial lime and soda ash can easily be bought at prices enough below these to offset the difference in amount of pure $\mathrm{CaO}$ and $\mathrm{Na}_{2} \mathrm{CO}_{3}$. The figures form an approximate measure of the value of the water for steaming purposes. There is a great difference between the cost of 0.27 cent per 1,000 gallons for Lake Michigan or 0.16 cent for Cache River and the cost of over 1 cent for Vermilion River at Streator or Fox Piver at Ottawa. The range from 0.6 cent to 1.1 cents per 1,000 gallon` will, however, include the river waters which are most used. The rise from about 0.4 cent at Moline and Quincy to 0.65 cent at Chester shows the great influence of Missouri River on the quality of the I Mississippi River water.

The actual cost of softening 1,000 gallons of we.ter from any of these rivers would of course be much more than is given in the table, for it must include depreciation of the plant, interest on the investment, and expense of operation. These items depend, however, more on the size of the installation than on the quality of the water. In a few places the great variability in quality causes a slight increase in the cost of operation by requiring special care tc make the doses of chemicals correspond to the variations in the water, but it is more usual to allow this variation in quality to appear in the over or under treatment of the water, the dose remaining the same. 
TABLF. 18.-Cost of softening Illinois surface waters.

\begin{tabular}{|c|c|c|c|c|}
\hline \multirow{2}{*}{ Source. } & \multirow{2}{*}{ Station. } & \multicolumn{2}{|c|}{$\begin{array}{l}\text { Chemicals requi ed per } \\
\text { thousand gallons. }\end{array}$} & \multirow{2}{*}{$\begin{array}{l}\text { Cost per } \\
\text { thousand } \\
\text { gallons. }\end{array}$} \\
\hline & & $\begin{array}{l}\text { Lime } \\
(\mathrm{CaO})\end{array}$ & $\begin{array}{l}\text { Soda ash } \\
\left(\mathrm{Na}_{2} \mathrm{CO}_{3}\right)\end{array}$ & \\
\hline Lake Michlgan.. & Chicago.. & $\begin{array}{c}\text { Pounds. } \\
0.78\end{array}$ & $\begin{array}{c}\text { Pounds. } \\
0.03\end{array}$ & $\begin{array}{l}\text { Cents. } \\
0.27\end{array}$ \\
\hline Reservoir....... & Cartter... & .20 & .08 & .16 \\
\hline & Marion.. & .35 & .26 & .41 \\
\hline & Cypress. & .39 & .16 & .31 \\
\hline & Joppa.... & .24 & .06 & .14 \\
\hline Rock River.. & Rockford. & 1. 45 & .07 & .52 \\
\hline Do.............. & Sterling.... & 1.53 & .16 & .64 \\
\hline Kankakee River. & Kankakee... & 1.23 & .48 & .94 \\
\hline Fox River........ & Elgin .......... & 1.60 & .27 & .80 \\
\hline & Ottawa.. & 1.67 & .49 & 1.09 \\
\hline Vermilion River (of Illinois River) ... & Streator.. & 1.48 & .52 & 1.07 \\
\hline Sangamon River......................... & Decatur.... & 1.52 & .21 & .71 \\
\hline & Springfield $\ldots . . .$. & 1. 41 & .23 & .69 \\
\hline Do........ & Chandlerville. & 1.46 & .20 & .68 \\
\hline Illinois River. & La Salle........ & 1. 20 & .42 & .87 \\
\hline Do......... & Peoria....... & 1. 16 & .40 & .83 \\
\hline Do $\ldots \ldots \ldots \ldots$ & Kampsville.. & 1.16 & .31 & .72 \\
\hline Kaskaskia River.. & Shelby ville.... & 1.51 & .21 & .70 \\
\hline Mo Do............. & Carlyle......... & 1.20 & .22 & .62 \\
\hline $\begin{array}{l}\text { Muddy River } \\
\text { Mississipoi River..... }\end{array}$ & Murphysboro.. & .51 & .47 & .71 \\
\hline Mississippi River.... & Moline ......... & .83 & .10 & .37 \\
\hline Do.................................. & Quincy.. & .98 & .10 & .41 \\
\hline Vermilion River of wabash kiver & $\begin{array}{l}\text { Chester........ } \\
\text { Danville...... }\end{array}$ & $\begin{array}{r}.98 \\
1.41\end{array}$ & .29 & .64 \\
\hline Embarrass River.................... & Charleston....... & 1.41 & .079 & .05 \\
\hline Do.................. & Lawrenceville........... & 1. 11 & .25 & .63 \\
\hline Little Wabash River. & Carmi................... & .51 & .14 & .32 \\
\hline Cache River & Mounds. & .44 & .02 & .16 \\
\hline
\end{tabular}

\section{CONCLUSIONS.}

1. Compared with surface waters of the United States as a whole, the surface waters of Illinois are fairly uniform in quality throughout the State.

2. The best large supply of water in the State is Lake Michigan.

3 . Water in the reservoirs and rivers of the southern part of the State is softer than that of northern rivers. The turbidity is less in the northern rivers and is much more easily removed than that of the southern streams.

4. None of the river waters are clear enough to furnist a satisfactory city supply without treatment. Treatment which will clarify the water and give it a pleasing appearance can be made to yield from most rivers a water safe for drinking.

5. The value for industrial use of nearly all the surface waters may be greatly increased by softening.

6. The daily and seasonal variations in quality render necessary careful daily supervision to insure the best results in any form of purification.

7. The quality of Illinois River water is made more uniform by the operation of the Chicago drainage canal.

8. The impounding of flood waters for the purpose of regulating the discharge of the rivers would greatly improve the quality of the water. 
The turbidity would be decreased, and the variations in amount of dissolved material would be much less. The extreme values occur in the times of very high and very low water, which would be eliminated by the impounding.

\section{ANALYTICAL TABLES.}

TABLE 19.-Mineral analyses of water from reservoir near Cartter, Ill.

[Parts per million unless otherwise stated.]

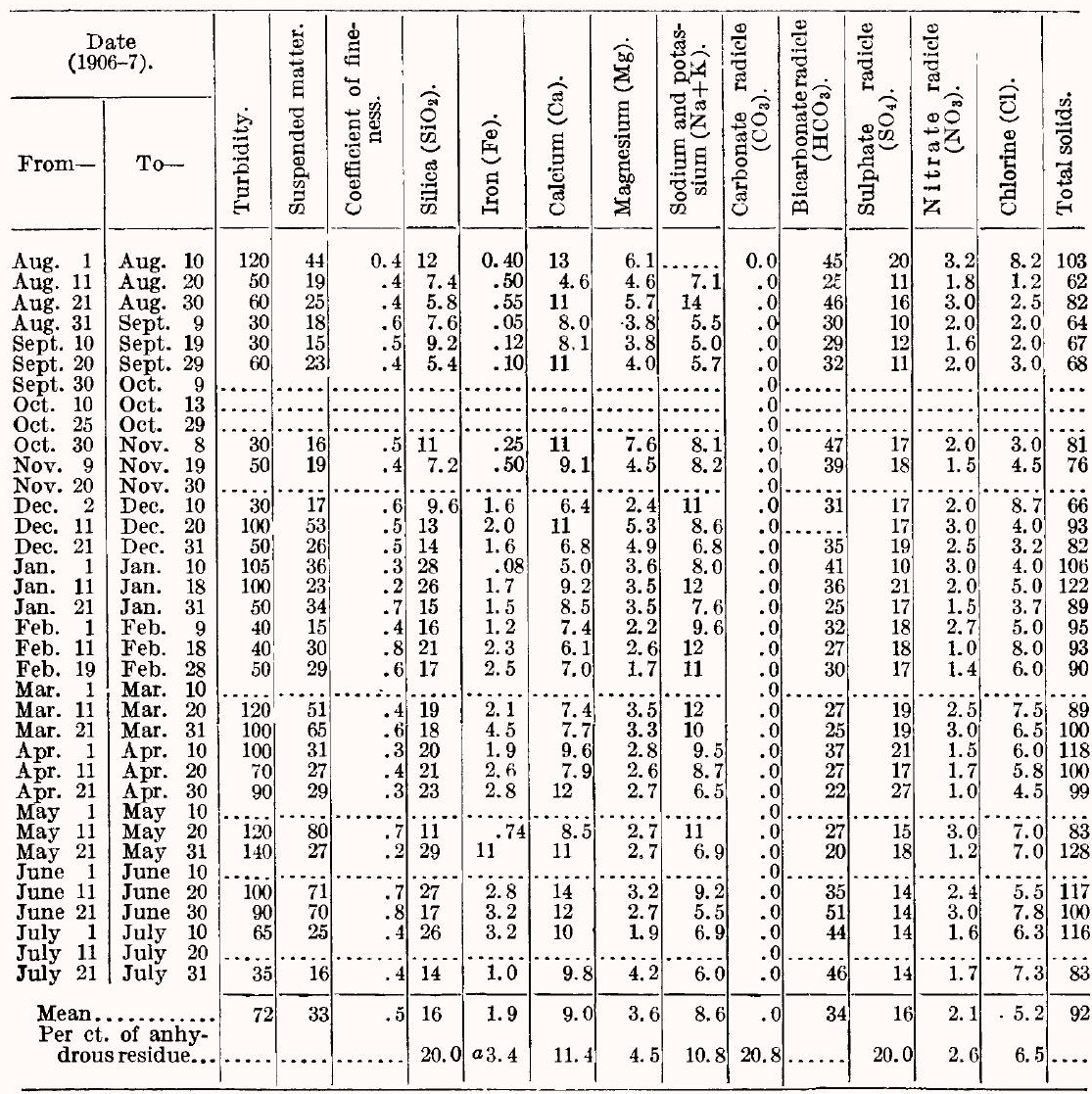


TABLE 20.-Mineral analyses of water from reservoir near Marion, Ill.

[Parts per million unless otherwise stated.]

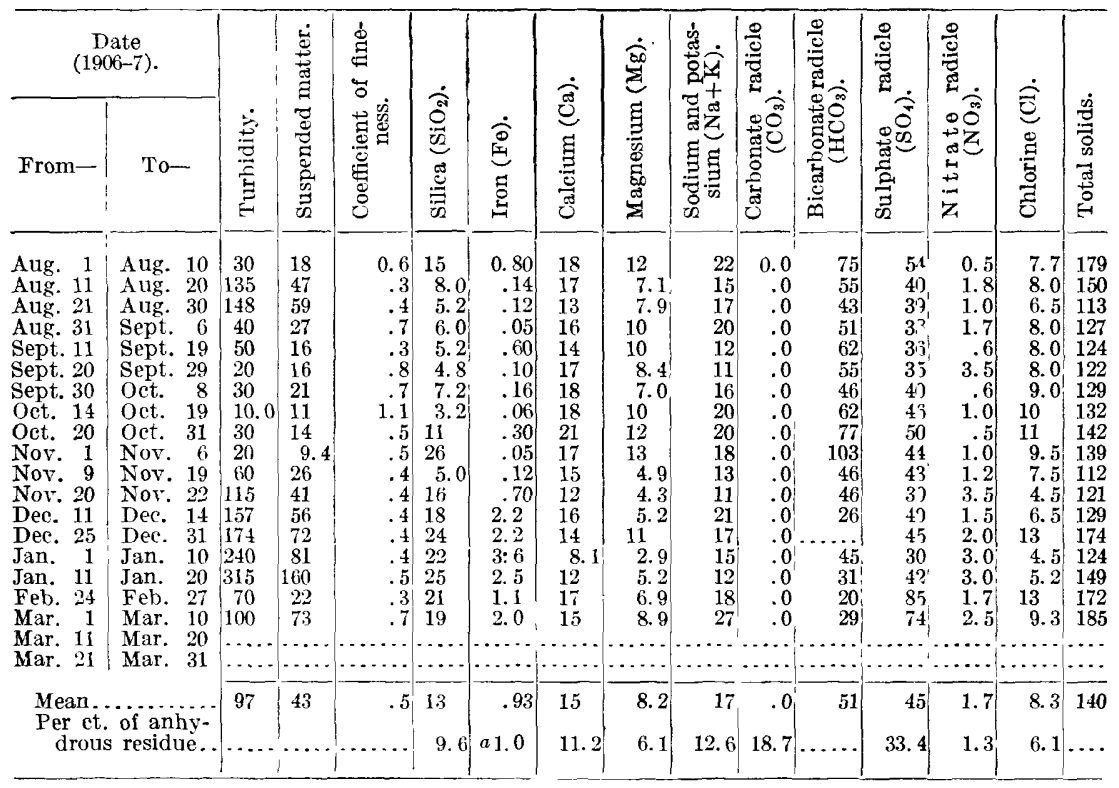

$a \mathrm{Fe}_{2} \mathrm{O}_{3}$. 
TABLE 21.-Mineral analyses of water from reservoir near Cypress, Ill.

[Parts per million unless otherwise stated.]

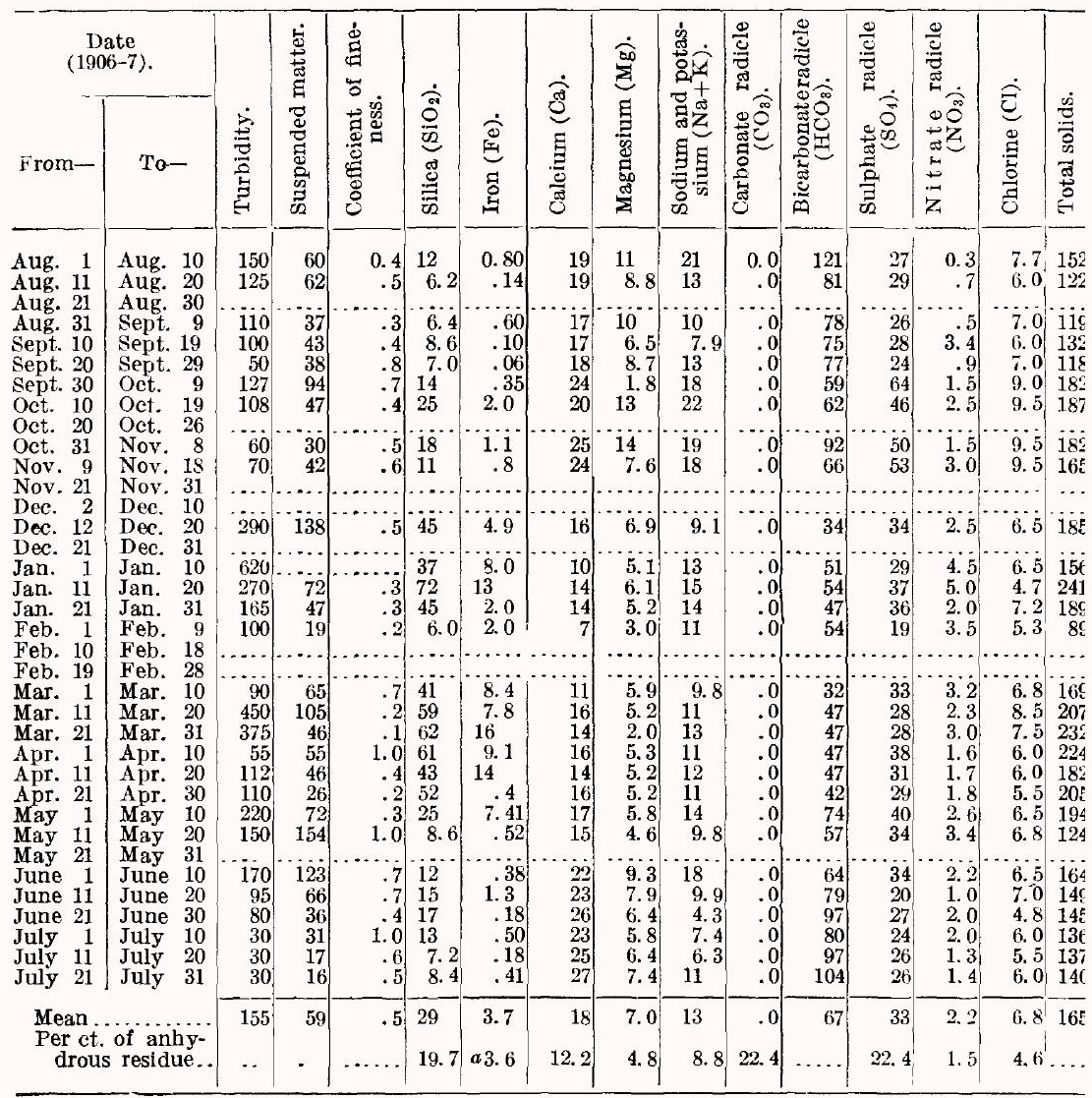


TABLE 22.-Mineral analyses of water from reservoir near Jopra, Ill.

[Parts per million unless otherwise stated.]

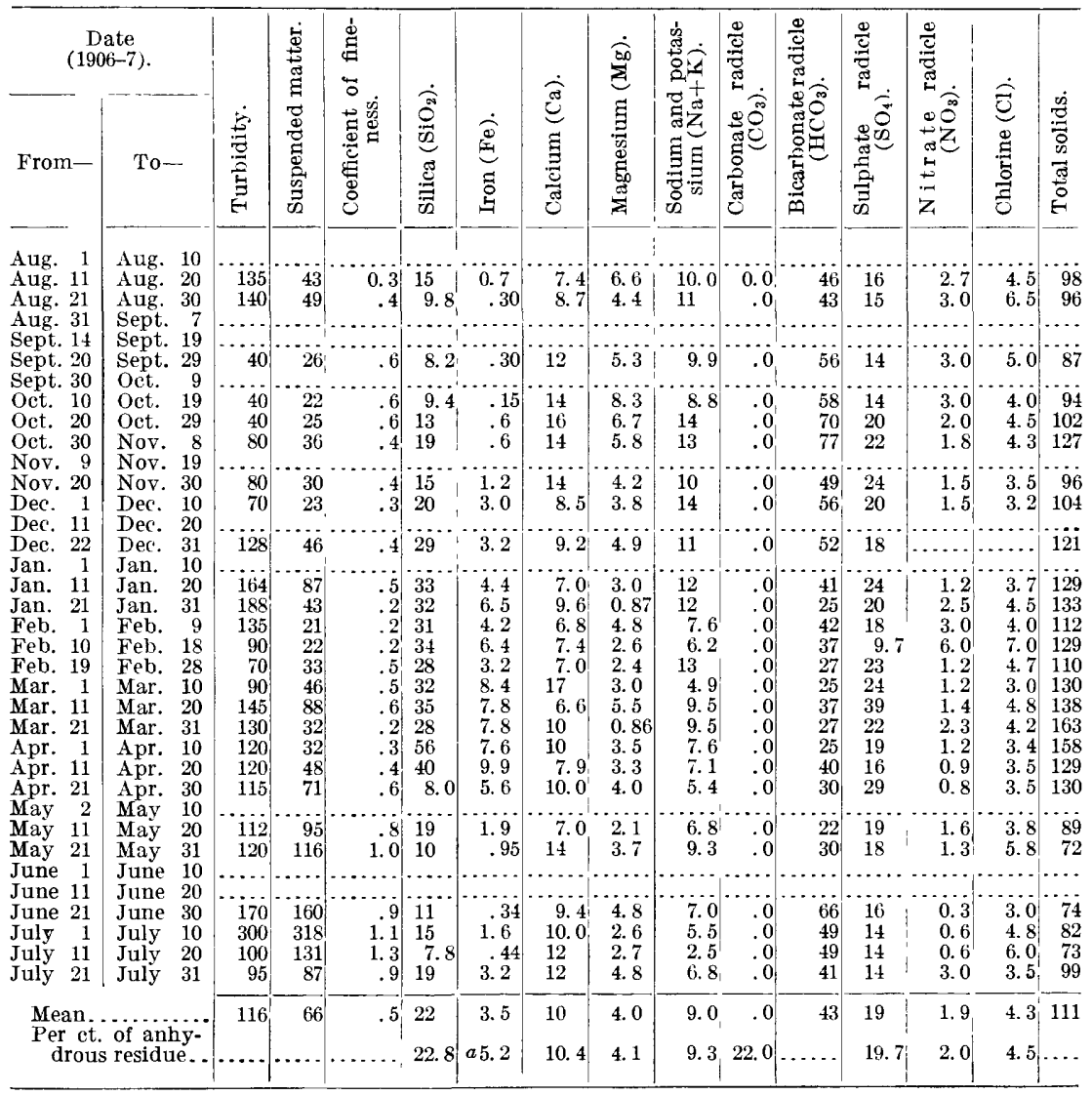

$a \mathrm{Fe}_{2} \mathrm{O}_{3}$.

28987 -IRR $239-10-5$ 
TABLE 23 --.Mineral analyses of water from Rock River near Rockford, Ill.

[Parts per million unless otherwise stated.]

\begin{tabular}{|c|c|c|c|c|c|c|c|c|c|c|c|c|c|c|c|c|}
\hline$\underset{(19}{\mathrm{I}}$ & & & & 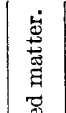 & $\begin{array}{l}\stackrel{d}{\Xi} \\
\overleftrightarrow{0}\end{array}$ & $\dot{\sigma}$ & & 苞 & 这 & 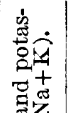 & 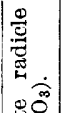 & 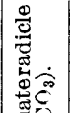 & 兽 & 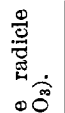 & $\stackrel{\widehat{\theta}}{0}$ & \\
\hline From- & To- & & E & 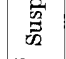 & 8 & $\stackrel{\leftrightarrows}{\leftrightarrows}$ & 옵 & 㞧 & 焉 & 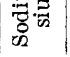 & 总 & 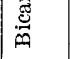 & 望 & $\bar{z}$ & 㕺 & 密 \\
\hline ug. 1 & ug. & & 450 & 198 & 0.4 & 14 & 0.20 & 32 & 19 & 11 & 0.0 & 187 & 17 & 3.0 & 5.5 & 207 \\
\hline 11 & & & & & .5 & 22 & & & & 11 & .0 & 174 & 21 & 3.6 & 2.5 & 198 \\
\hline 21 & $\mathrm{Au}$ & 30 & 310 & 142 & .4 & 19 & 1.7 & 28 & 1 & 11 & .0 & 161 & 16 & & 0 & 179 \\
\hline 31 & & 9 & 148 & 78 & .5 & 20 & .12 & 40 & 26 & 7.9 & .0 & 2 & 2 & 3 & 4.5 & 249 \\
\hline 10 & & 19 & 140 & 65 & .5 & 6.6 & .50 & 41. & & 11 & .0 & 27 & 18 & 3. & 4.5 & 229 \\
\hline .20 & Sept & 29 & 60 & 34 & 6 & 15 & .08 & 54 & 33 & 18 & .0 & 23 & 15 & 4. & 5.5 & 275 \\
\hline t. 30 & Oct. & 8 & 60 & 43 & .7 & 8.8 & .04 & 44 & & 10.0 & .0 & $2 \div ?$ & 16 & 4 & 4.5 & 243 \\
\hline ct. 10 & Oct. & 18 & 30 & 19 & .6 & 13 & .07 & 52 & 26 & 13 & .0 & 31.5 & 17 & 4.0 & 5.0 & 296 \\
\hline . 20 & Oct. & 29 & & & & & & & & & & & & & & \\
\hline v. 1 & Nov. & 8 & 20 & 11 & .6 & 13 & .05 & 53 & 33 & 12 & .0 & $3 \geqslant 0$ & 19 & 5.0 & 4.5 & 286 \\
\hline ข. 10 & Nov. & 19 & 10.0 & 4.0 & .4 & 11 & .04 & 55 & 32 & 7.5 & .0 & $3^{14}$ & 21 & 3.5 & 6.0 & 287 \\
\hline .20 & Tov. & 29 & & & & & & & & & & & & & & \\
\hline 1 & Dec. & 10 & 20 & 17 & .9 & 13 & .07 & 48 & 32 & 9.5 & .0 & 231 & 21 & 4.0 & 5.2 & 256 \\
\hline 11 & I & 2 & 15 & 6.4 & .4 & 12 & .13 & 52 & 32 & 13 & .0 & 310 & 25 & 4. & 7.5 & 295 \\
\hline 21 & Dec. & 31 & 10.0 & 0 16 & $1 . \overline{6}$ & 18 & .14 & & 34 & 14 & .0 & 317 & 3 & 4. & 5.5 & 320 \\
\hline - 1 & Jan. & 10 & 380 & 150 & .4 & 21 & 1.5 & 3 & 19 & 16 & .0 & 18 & 28 & 4. & 3.5 & 218 \\
\hline 11 & & 2 & & 354 & 1.2 & 18 & & & & 10 & .0 & & & & 4. & 228 \\
\hline 21 & Jan. & 31 & 177 & 96 & .5 & 17 & 1.2 & 2 & 1 & 11 & .0 & 139 & 1 & 3. & 5.0 & 173 \\
\hline . 1 & & 7 & 50 & 3 & .6 & 22 & .7 & 3 & & 12 & .0 & 234 & 3 & & 5.0 & 243 \\
\hline eb. 10 & Feb. & 18 & 40 & 23 & .6 & 18 & .26 & 46 & 25 & 9.0 & .0 & 235 & 2 & 5. & 5.5 & 261 \\
\hline b. 19 & Feb. & & 80 & 39 & .5 & 13 & 1.8 & 34 & 17 & 9.2 & .0 & 176 & 19 & 4. & 6.0 & 194 \\
\hline Mar. 1 & Mar. & 1 & 20 & 16 & .8 & 13 & .25 & 44 & 26 & 7.9 & .0 & 2.27 & 22 & 7.0 & 5.8 & 233 \\
\hline Mar. 11 & Mar & & 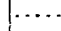 & 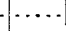 & $\cdots$ & $\ldots$ & $\cdots$ & & & & $\cdots$ & & & $\cdots$ & $\cdots \cdot$ & $\cdots$ \\
\hline 21 & & & & & & & & & & & & & & & & \\
\hline 1 & pr. & 10 & 270 & 270 & 1.0 & 16 & .39 & 41 & 20 & 7.6 & .0 & 2) 8 & 24 & 2.8 & 2.8 & 223 \\
\hline - 11 & & & & & & & & & & & & & & & & \\
\hline 21 & & & 35 & 24 & .7 & 8.0 & .16 & 50 & 36 & 4.8 & .0 & 2334 & 24 & 2.5 & 5.0 & 266 \\
\hline y 1 & & & & & & & & & & & & & & & & \\
\hline $\begin{array}{ll}y & 11\end{array}$ & May & 2 & 40 & 45 & 1.1 & 9.2 & .15 & 52 & 22 & 8.2 & .0 & $2 ?$ & 25 & 9.0 & 3.0 & 306 \\
\hline y 21 & $\mathrm{Ma}$ & & & 75 & 1.1 & 8.8 & .15 & 51 & 27 & 11 & .0 & $2 ? 7$ & & 3. & 0 & 268 \\
\hline e 1 & June & 1 & 80 & 70 & .9 & 8.6 & .26 & & & 8. & .0 & 237 & 2 & 3. & 0 & 268 \\
\hline e 11 & & & 100 & 107 & 1.1 & 8.8 & .18 & 5 & & 7. & .0 & 272 & & & & 27 \\
\hline e 21 & & 3 & & & .9 & 15 & .17 & & & 9. & .0 & $2 ?$ & & 3. & & 28 \\
\hline 1 & July & 10 & 2 & 192 & .9 & 21 & .78 & 5 & 2 & 7. & .0 & 23 & & 6. & 5 & 243 \\
\hline 11 & & 2 & & & .7 & 18 & .54 & 53 & & 7.2 & .0 & 2) 3 & & b. & 3. 0 & 239 \\
\hline July 21 & July & 31 & 340 & 241 & .7 & 28 & .38 & 48 & 24 & 11 & .0 & 226 & 20 & 2.5 & 6.0 & 247 \\
\hline Mean & & & 134 & 92 & 7 & 15 & .44 & 45 & 25 & 10 & 0 & 252 & 22 & 4. 1 & 4. 6 & 250 \\
\hline $\begin{array}{l}\text { Per } \\
\text { dro }\end{array}$ & & & & & & 6.0 & U. & 8. 0 & 10.0 & & 49.6 & & 0.0 & 1.0 & 1.8 & \\
\hline
\end{tabular}

a $\mathrm{Fe}_{2} \mathrm{O}_{3}$. 
TABLE 24.-Mineral analyses of water from Rock River near Sterling, Ill.

[Parts per million unless otherwise stated.]

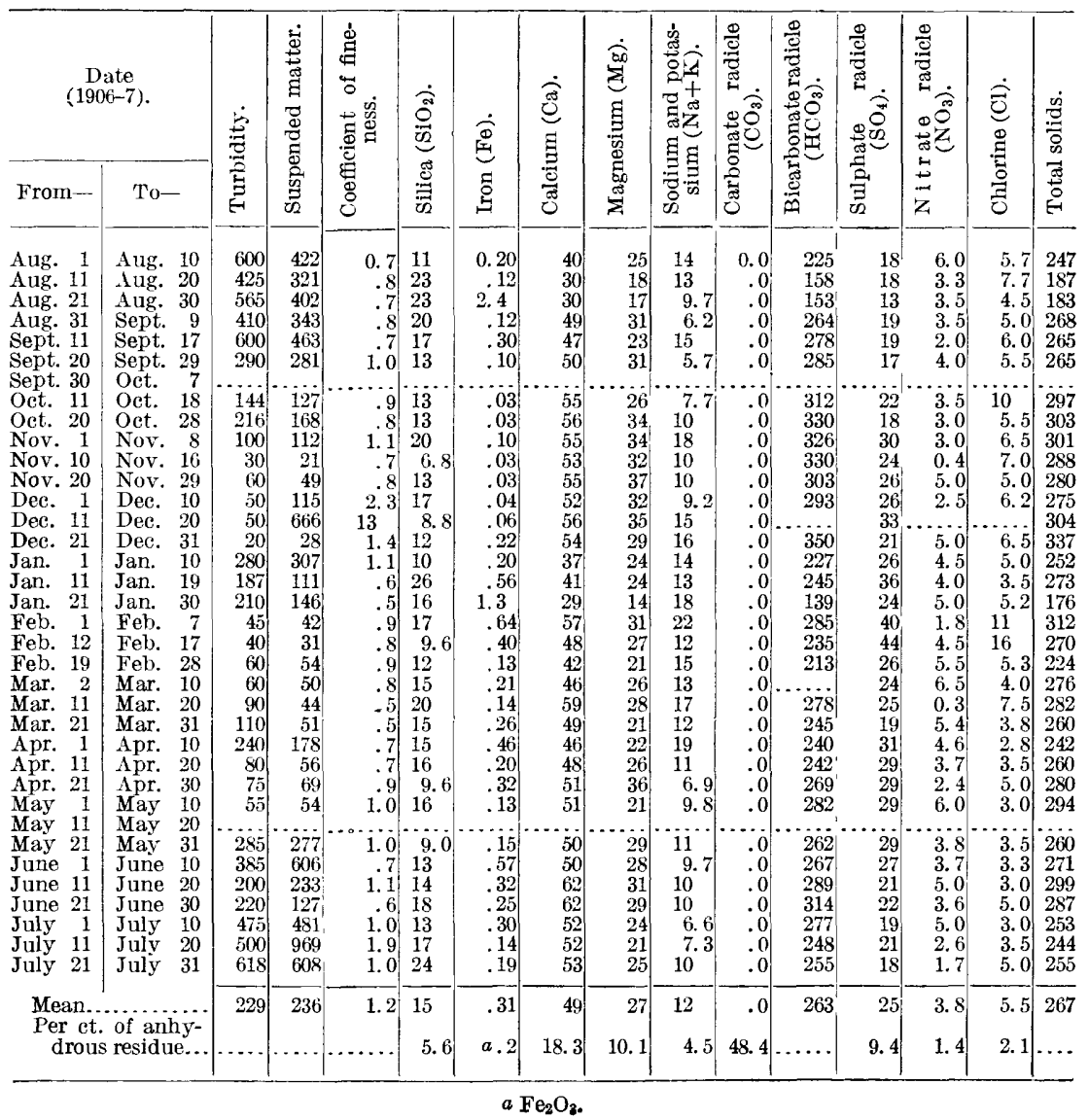


TABLE 25.-Mineral analyses of water from Kankakee River near Kankakee, Ill.

[Parts per million unless otherwise stated.]

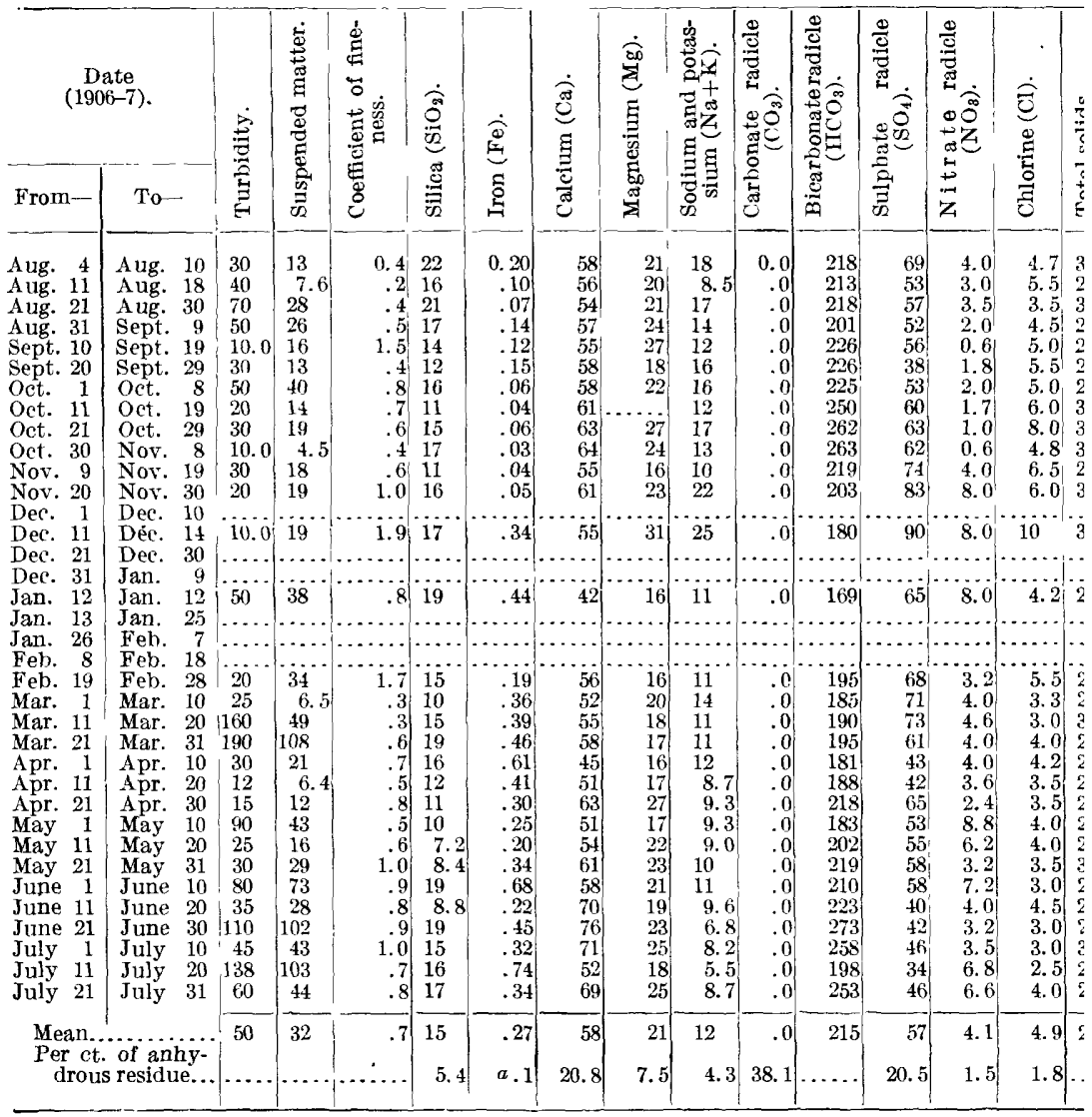

a $\mathrm{Fe}_{3} \mathrm{O}_{3}$. 
TABLE 26.--Mineral analyses of water from Fox River near Elgin, Ill.

[Parts per million unless otherwise stated.]

\begin{tabular}{|c|c|c|c|c|c|c|c|c|c|c|c|c|c|c|c|}
\hline & & & 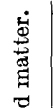 & 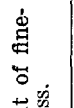 & $\dot{\sigma}$ & & $\overparen{\Xi}$ & $\underset{\dot{\theta}}{\dot{8}}$ & 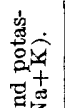 & 总 & 总 & 莺 & 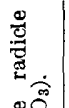 & $\dot{\overrightarrow{0}}$ & $\dot{\ddot{d}}$ \\
\hline From- & To- & 总 & 总 & $\begin{array}{l}\text { ष्ष } \\
\text { ठ․ }\end{array}$ & 苞 & 莡 & 窇 & 范 & 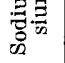 & 응 & 葪 & 点 & $\stackrel{ \pm}{z}$ & 节 & 丞 \\
\hline ug. 3 & ug. 10 & 110 & 39 & 0.4 & 26 & 0.20 & 42 & 36 & 11 & 0.0 & 283 & 27 & 2.5 & 6.0 & 304 \\
\hline 11 & 20 & 30 & 8.4 & .3 & 15 & .10 & & 35 & 10 & .0 & 240 & 21 & 3.4 . & 4.7 & 270 \\
\hline .21 & lg. 30 & 50 & 30 & .6 & 10 & & & 34 & 19 & .0 & 252 & 21 & 3. & 7.0 & 280 \\
\hline Aug. 31 & pt. 8 & 50 & 7.0 & .1 & 12 & .05 & & 34 & 17 & .0 & 291 & 29 & 1.2 & 6.5 & 264 \\
\hline 11 & t. 19 & 50 & 31 & .6 & 9.4 & .20 & & & 14 & .0 & 26 & 29 & 1. & 5.0 & 234 \\
\hline 20 & pt. 29 & 40 & 30 & .8 & 9.4 & .03 & & 29 & 10 & .0 & 273 & 24 & 2.0 & 6.5 & 265 \\
\hline 30 & $\mathrm{Oec}^{+} .9$ & 40 & 2 & .5 & 7.0 & .03 & & 34 & 11 & .0 & 254 & 49 & 1. & 5. 0 & 252 \\
\hline Oct. 10 & Oct. 18 & 20 & 15 & .8 & 5.8 & .08 & & 35 & 7.7 & .0 & 270 & 31) & 1.2 & 5.5 & 265 \\
\hline 20 & Oct. 29 & 30 & 21 & .7 & 8.2 & .0 & & 37 & 19 & .0 & 300 & & 0.6 & 7.2 & 285 \\
\hline . 1 & Nov. 8 & 20 & 10.0 & .5 & 10 & .04 & & 35 & 10 & .0 & 316 & 36 & 1. & 7.5 & 306 \\
\hline Nor. 9 & Nov. 19 & 10.0 & 4. 4 & .4 & 6.0 & .03 & & 3 & 13 & .0 & 310 & 36 & & & 289 \\
\hline 20 & ov. 30 & 15 & 13 & .9 & 8. & & & 37 & 14 & .0 & 300 & 45 & 3. & 7.0 & 29.3 \\
\hline 1 & Dee. 10 & 10.0 & 5.2 & .5 & 11 & . & & & 12 & .0 & 300 & & 4. & & 315 \\
\hline 11 & Dec. 20 & 10. & 24 & .2 & 10 & .1 & & 37 & 8.8 & .0 & 309 & 46 & 2 . & 6. & 348 \\
\hline Dec. 21 & bec. 31 & 5. & 9.6 & .2 & 9.2 & .12 & & 39 & 13 & .0 & 365 & 53 & 3. & 5.5 & 373 \\
\hline Jan. 1 & Jan. 10 & 40 & 18 & .4 & 20 & .07 & 61 & 20 & 18 & .0 & 309 & 51 & 3.5 & 6.0 & 378 \\
\hline . 11 & . 20 & & & & & & & & & & & & & & \\
\hline . 21 & n. 31 & 50 & 27 & .5 & 14 & .64 & 40 & 22 & 10 & 0 & 18 & 42 & 2.5 & 7.0 & 249 \\
\hline b. 1 & Feb. 9 & 15 & 10.0 & .7 & 14 & .20 & & 30 & 10 & .0 & 250 & 49 & 3.0 & 6. 2 & 310 \\
\hline . 10 & Feb. 18 & 7.0 & 8. & 1.2 & 15 & .13 & & & 8.4 & .0 & 231 & 42 & 4. & 0 & 317 \\
\hline Feb. 19 & Feb. 28 & 15 & 9. & .6 & 12 & .13 & 4 & 23 & 14 & .0 & 22 & 44 & 4. & 6.5 & 265 \\
\hline r. 1 & Mar. 10 & 5. 0 & 6.4 & 1.3 & 11 & .36 & & & 13 & .0 & 232 & & 2 . & 4.3 & 274 \\
\hline Mar. 11 & Mar. 20 & 10.0 & 9.8 & 1.0 & 12 & .27 & & 21 & 10 & .0 & 245 & 40 & 1. 7 & 5. 0 & 277 \\
\hline Mar. 21 & Iar. 31 & 25 & 12 & .5 & 11 & & & & 7.7 & .0 & 235 & 45 & 1. & 5.5 & 258 \\
\hline Apr. 1 & Apr. 10 & 25 & 23 & 1.0 & 10 & .13 & 54 & 25 & 7.4 & .0 & 256 & 35 & 1.7 & 5. 5 & 277 \\
\hline . 11 & Ap & & & & & & & & & & & & & & \\
\hline r. 21 & Apr. 30 & 25 & 21 & .8 & 10 & 28 & 5 & 34 & 11 & .0 & 267 & 43 & & 2.3 & 292 \\
\hline y 1 & $\mathrm{Ma}$ & 20 & 15 & .8 & 11 & .12 & 5 & 22 & 10 & .0 & 247 & 48 & 2. & 4.0 & 304 \\
\hline 11 & 2 & 3 & 4 & 1. 4 & 20 & & & & 9.0 & .0 & 292 & 47 & & 3 & 329 \\
\hline 21 & 3 & 5 & 5 & 1.0 & 12 & .1 & & 2 & 5. & .0 & 23.1 & 50 & 2 . & 3.5 & 273 \\
\hline$e^{-1}$ & e 10 & 3 & 3 & 1.0 & 11 & & & & 5. & .0 & 2 & & & 3. & 292 \\
\hline e 11 & e 20 & 8 & 4 & .6 & 9. 2 & & 6 & & 8. & .0 & 26 & 32 & 1. & 3.5 & 281 \\
\hline e 21 & e 30 & 8 & 5 & & 16 & & & 3 & 5. & .0 & 27 & & & 3.0 & 308 \\
\hline July 1 & July 10 & 50 & 5 & 1.1 & 12 & .1 & 5 & 31 & 10 & .0 & 27 & 2 & 2. & 5 & 291 \\
\hline July 11 & July 20 & 5 & 50 & .9 & 12 & .1 & & & 8. & .0 & 27 & 35 & 2 & 2.5 & 284 \\
\hline July 21 & July 31 & 35 & 31 & .9 & 17 & .17 & & 29 & 6.6 & .0 & 273 & 26 & 2.0 & 3.3 & 269 \\
\hline Mean. & & 34 & 23 & .7 & 12 & .15 & 51 & 30 & 11 & .0 & 268 & 38 & 2.4 & 5.2 & 290 \\
\hline Per ct & of anhy- & & & & 4.3 & $a .1$ & 18.1 & 10.6 & 3. & 46.8 & & 13.5 & 0.9 & 1.8 & \\
\hline
\end{tabular}

a $\mathrm{Fe}_{2} \mathrm{O}_{3}$. 
TABLE 27.--Mineral analyses of water from Fox River near Ottawa, Ill.

[Parts per million unless otherwise stated.]

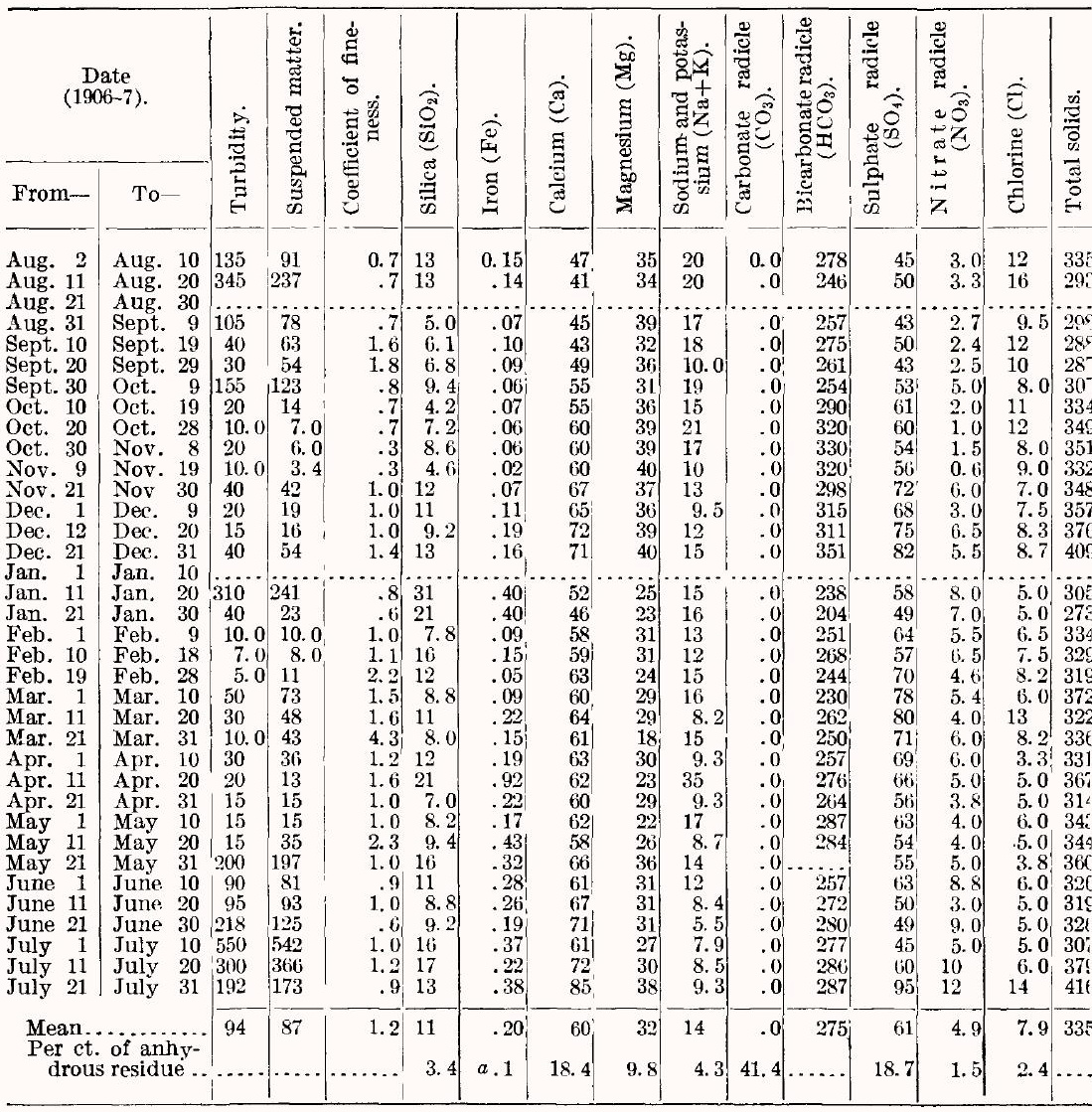

$a \mathrm{Fe}_{2} \mathrm{O}_{3}$. 
TABLE 28.-Mineral analyses of water from Termilion River near Streator, Ill.

[Parts per million unless otherwise stated.]

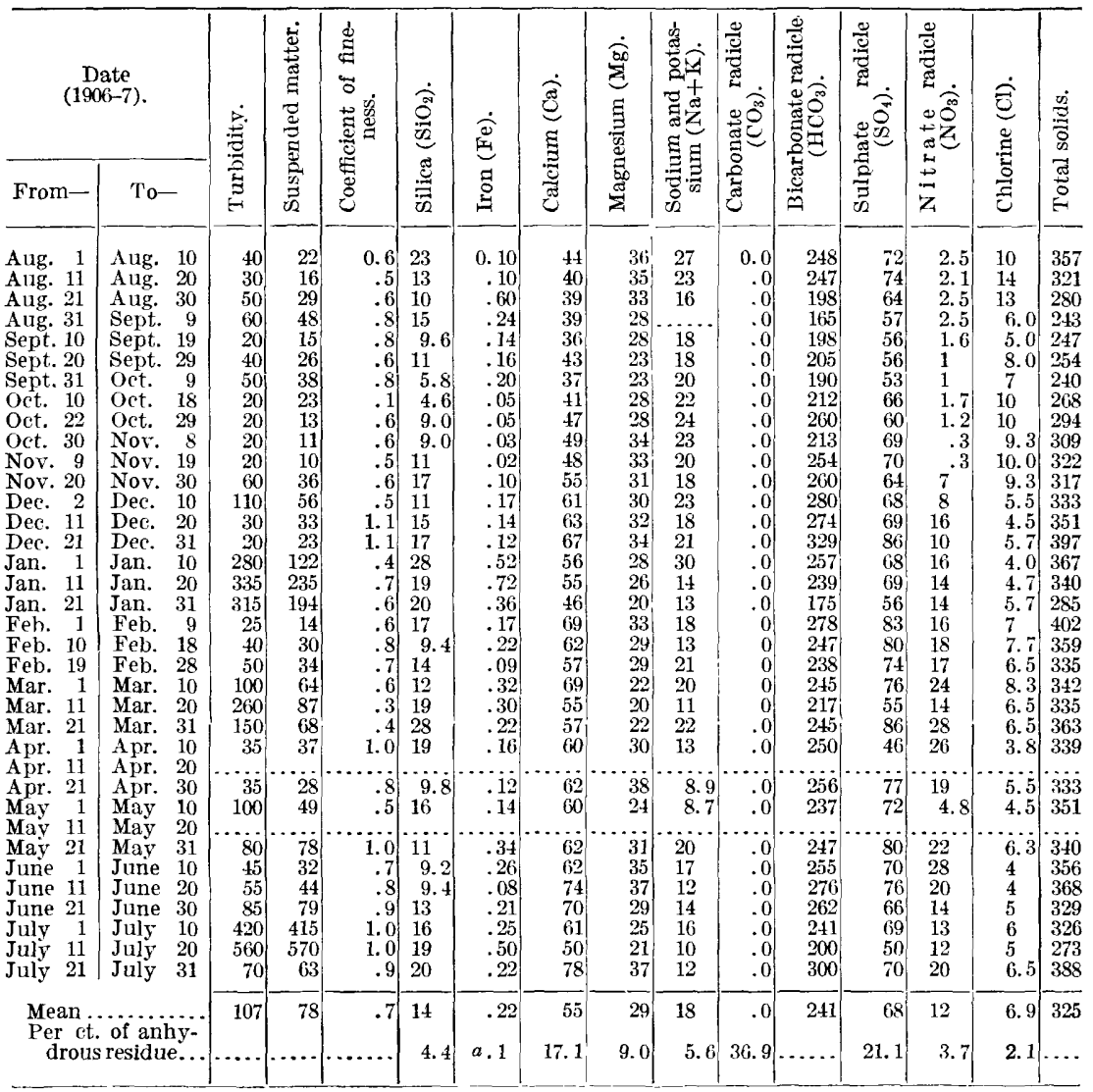

a $\mathrm{Fe}_{2} \mathrm{O}_{3}$. 
TABLE 29.--Mineral analyses of water from Sangamon River near Decatur, $17 l$.

[Parts per million unless otherwise stated.]

\begin{tabular}{|c|c|c|c|c|c|c|c|c|c|c|c|c|c|c|c|c|}
\hline$\underset{(190}{D}$ & & & 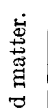 & $\begin{array}{l}\stackrel{d}{ٌ} \\
\stackrel{\Xi}{0} \\
\ddot{0} \dot{0}\end{array}$ & $\dot{\hat{\sigma}}$ & & రే & $\underbrace{30}_{\Xi}$ & 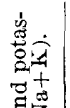 & 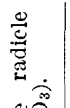 & 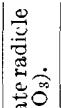 & 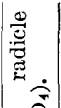 & $\stackrel{0}{\stackrel{0}{\mathcal{D}}}$ & $\dot{\tilde{\theta}}$ & $\dot{2}$ & . \\
\hline From- & To- & $\vec{B}$ & $\frac{\sqrt[n]{2}}{2}$ & 8 & $\cong$ & $\stackrel{0}{0}$ & ฮี & $\stackrel{5}{\Xi}$ & in & 氖 & $\ddot{\mathscr{n}}$ & 哆 & $\vec{z}$ & हี & 苛 & 晃 \\
\hline ug 1 & Aug. 10 & 240 & 107 & 0.4 & 26 & 0.2 & 46 & 21 & 13 & 0.0 & 223 & 20 & 4.5 & 8.2 & 262 & \\
\hline 11 & & 260 & 121 & .5 & 20 & .2 & & 20 & 48.8 & .0 & 214 & 23 & 4.8 & 3.5 & 233 & \\
\hline 21 & A & 270 & 106 & .5 & 18 & .06 & & 22 & 8.5 & .0 & 235 & 25 & 4.0 & 2.7 & 264 & \\
\hline 31 & . 9 & 117 & 51 & .4 & 17 & .09 & 61 & 27 & 13 & .0 & 305 & 26 & 4.0 & 4.5 & 297 & \\
\hline .10 & 19 & & & & & & & & & & & & & & & \\
\hline 21 & ept. 2 & 7 & 43 & .6 & 15 & .03 & 55 & 24 & 18 & 0 & 315 & 22 & 2.5 & 10 & 302 & \\
\hline ct. 1 & Oct. 9 & 6 & 40 & .7 & 12 & .05 & 54 & 30 & 15 & .0 & 283 & 26 & 3.0 & 5.5 & 286 & \\
\hline 10 & Oct. 19 & 20 & 13 & .6 & 10 & .15 & 5 & 30 & 21 & .0 & 297 & 27 & 2 & 5.0 & 275 & \\
\hline bet. 20 & 29 & 50 & 33 & .7 & 11 & .06 & 64 & 35 & 20 & .0 & 353 & 21 & 1. & 9.0 & 332 & \\
\hline ov. 1 & ov. 8 & 30 & 19 & .6 & 15 & .10 & 67 & 44 & j9 & .0 & 380 & 33 & 1. & 7.8 & 338 & \\
\hline 9 & 17 & 20 & 13 & .6 & 11 & .02 & 5 & 28 & 16 & .0 & 360 & 25 & 0. & 8.5 & $324^{\prime}$ & \\
\hline 20 & 30 & 168 & 104 & .6 & 16 & .14 & 5 & 25 & 12 & .0 & 240 & 39 & 8. & 3.5 & 274 & \\
\hline Dec. 1 & Dec. 10 & $196^{\prime}$ & 110 & .6 & 17 & .40 & 51 & 28 & 13 & .0 & 278 & 37 & 7.0 & 5.5 & 283 & \\
\hline 11 & 20 & 30 & 27 & .9 & 29 & .16 & 5 & 30 & 21 & .0 & 285 & 36 & 6. & 5.5 & 316 & \\
\hline Dec. 22 & Dec. 31 & 25 & 31 & 1.2 & 15 & .28 & 62 & 30 & 12 & .0 & 314 & 42 & 8.0 & 7.0 & 332 & \\
\hline . 1 & Jan. 10 & & & & & & & & & & & & & & & \\
\hline 11 & in. 20 & 240 & 144 & .6 & 36 & .74 & 45 & 20 & 17 & .0 & 227 & 64 & 7.1 & 3.5 & 291 & 10.0 \\
\hline 21 & 31 & 220 & 85 & .4 & 40 & 1.9 & & 18 & 15 & .0 & 186 & 42 & 8.0 & 5.5 & 279 & \\
\hline . 1 & Feb. 8 & 20 & 20 & 1.0 & 23 & .13 & 59 & 28 & 15 & .0 & 290 & 43 & 12 & 5.2 & 319 & 96. \\
\hline . 11 & Feb. 18 & 2 & 22 & .9 & 22 & .07 & 5 & 22 & 1 & .0 & 231 & 40 & 10 & 8.0 & 317 & 6.0 \\
\hline .20 & Feb. & 2 & 22 & 1.0 & 21 & .1 & & 27 & 15 & .0 & 290 & 37 & 8.0 & 6.5 & 317 & 6.1 \\
\hline Iar. 1 & Mar. 10 & 20 & 19 & 1.0 & 14 & .1 & 5 & 29 & 15 & .0 & & 40 & 14 & 5.0 & 325 & \begin{tabular}{l|l}
5.9 \\
5
\end{tabular} \\
\hline 11 & 20 & $410^{\prime}$ & 336 & .8 & & .3 & & 20 & 14 & .0 & 192 & 32 & 8.0 & & 210 & 10.6 \\
\hline . 21 & Mar. 31 & 100 & 43 & .4 & 20 & .2 & 5 & 27 & 1 & 0 & 267 & 45 & 12 & 4.5 & 305 & 5.5 \\
\hline 1 & A & & 36 &.$y$ & & .1 & & 2 & 11 & .0 & 26 & 42 & 14 & & 287 & 6.9 \\
\hline . 11 & Apr. 20 & 10 & 10 & 1.0 & 15 & .23 & & 18 & 11 & .0 & 252 & 42 & & 4.5 & 292 & 5. \\
\hline . 21 & Ap & 3 & 2 & .9 & 1 & $?$ & 5 & 3 & 9.5 & .0 & 265 & 46 & 11 & & 286 & 5.5 \\
\hline 1 & $\mathbf{M}$ & 10 & 6 & .6 & 17 & .1 & 5 & 2 & 9. & .0 & 247 & 46 & 18 & b. & 292 & 6. \\
\hline 11 & May 20 & 6 & 49 & & 12 & .1 & 5 & 28 & 12 & .0 & 271 & 38 & 19 & 5. & 288 & 6.2 \\
\hline 21 & May 3 & 140 & 128 & .9 & 19 & .46 & & 30 & 9.8 & .0 & & 37 & 12 & 3.7 & 336 & 8. \\
\hline e 1 & June 1 & 95 & 88 & .9 & 16 & .30 & 53 & 24 & 14 & .0 & & 23 & 20 & 4.3 & 292 & 8. \\
\hline e 11 & $\mathrm{Ju}$ & & & & & & & & & & & & & & & \\
\hline June 21 & 30 & 340 & 318 & .9 & 19 & .60 & 54 & 21 & 7.7 & .0 & 218 & 26 & 14 & 2.0 & 240 & 7. \\
\hline July 1 & July 10 & & 63 & .7 & & & & & 10 & .0 & 287 & 29 & 9.0 & 5. & 334 & 5. \\
\hline July 11 & July 20 & 425 & 435 & 1.0 & 18 & .56 & 4 & 16 & 8.2 & .0 & 197 & 22 & 7.0 & 4.0 & 230 & 7.4 \\
\hline July 21 & July 31 & 210 & 156 & 7 & 21 & & 63 & 24 & 17 & .0 & 280 & 45 & 12 & 4.3 & 326 & \begin{tabular}{l|l}
6 & 7.4
\end{tabular} \\
\hline Mean & & 126 & 87 & .7 & 19 & .27 & 55 & 26 & 14 & .0 & 268 & 35 & 8.5 & 5.4 & 293 & \\
\hline Per ct. & & & & & & & & & & & & 11.9 & & & & \\
\hline
\end{tabular}

a $\mathrm{Fe}_{2} \mathrm{O}_{3}$. 
TA BLE 30.-Mineral analyses of water from Sangamon River near Springfield, Ill.

[Parts per-million unless otherwise stated.]

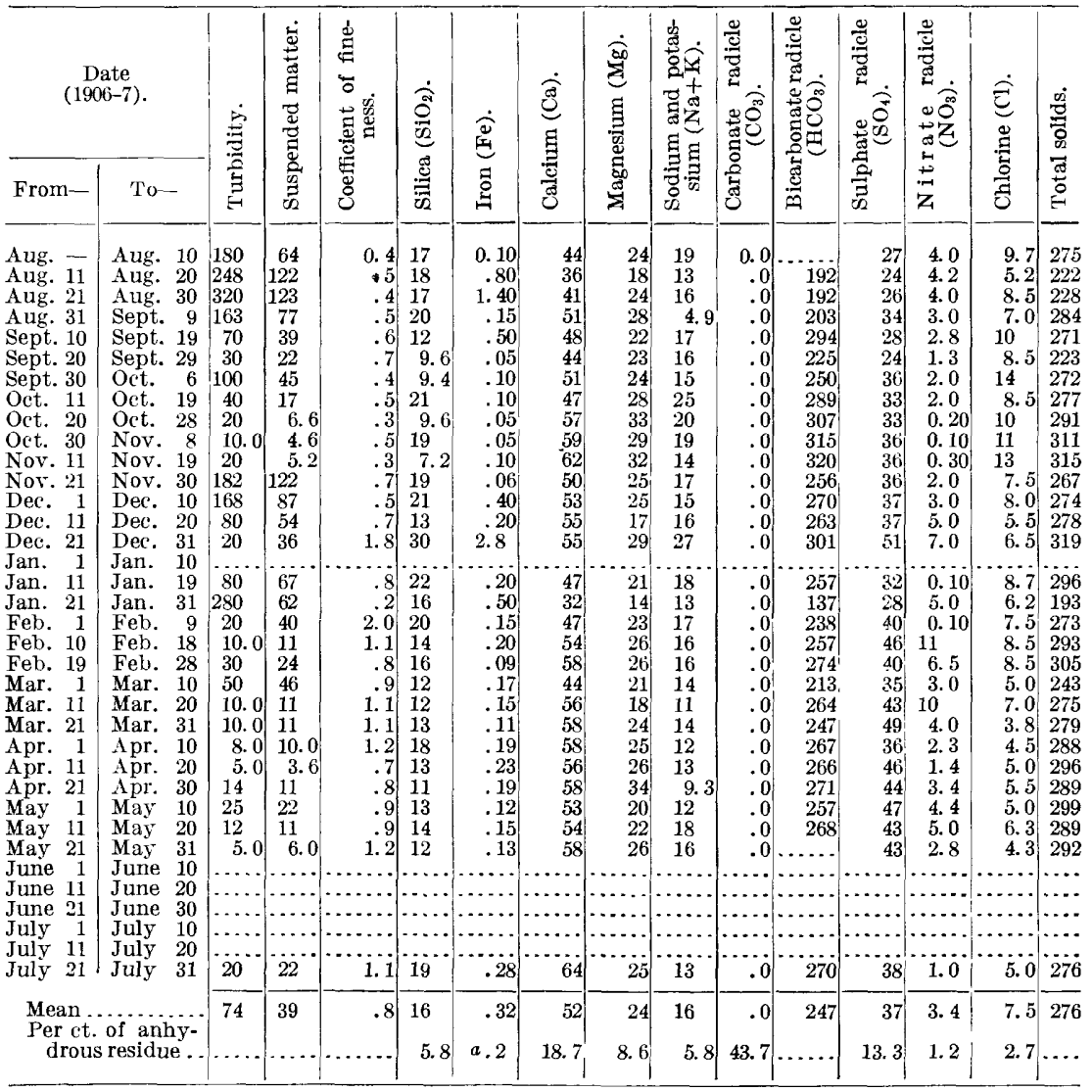

$a \mathrm{Fe}_{2} \mathrm{O}$. 
TABLE 31.-Mineral analyses of water from Sangamon River near Chandlerville, Ill.

[Parts per million unless otherwise stated.]

\begin{tabular}{|c|c|c|c|c|c|c|c|c|c|c|c|c|c|c|c|c|}
\hline & & & 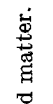 & 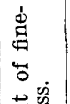 & & & ฮึ & $\sum_{\mathbb{g}}^{000}$ & 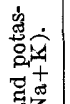 & 总 & 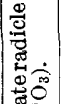 & 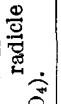 & 总 & $\dot{\overrightarrow{0}}$ & & 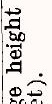 \\
\hline From- & To- & $\stackrel{5}{G}$ & 解 & 8 & 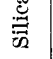 & 㺃 & 馬 & 疍 & 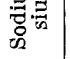 & ש & $\stackrel{\Xi}{\oplus}$ & $\begin{array}{l}\Xi \\
\overline{3}\end{array}$ & $\ddot{z_{1}}$ & 总 & $\begin{array}{l}\stackrel{5}{5 ే} \\
\stackrel{0}{0} \\
\text { E. }\end{array}$ & $\sum^{\infty}$ \\
\hline ug. 1 & 10 & 125 & 81 & 0.6 & 18 & 0.20 & 54 & 26 & 23 & 0.0 & 290 & 25 & 1.7 & 8.8 & 293 & 3.7 \\
\hline 11 & & 11 & 187 & 6 & 17 & .50 & 39 & 22 & 11 & .0 & 182 & 26 & 3.4 & 5.5 & 231 & 4.6 \\
\hline 21 & A & & 170 & 5 & 15 & .07 & 43 & 19 & 18 & .0 & 193 & 31 & 4.0 & 5.0 & 232 & 4. 2 \\
\hline 31 & t. 9 & 90 & 163 & .5 & 18 & .09 & 50 & 24 & 7.4 & .0 & 236 & 26 & 2.7 & 6.5 & 247 & 3.6 \\
\hline 10 & 19 & & 116 & .7 & 20 & .18 & 53 & 33 & 13 & .0 & 320 & 32 & 2.0 & 7.0 & 317 & 2.7 \\
\hline 20 & Sept. 23 & 1 & 105 & .8 & 17 & .06 & 51 & 27 & 16 & .0 & 325 & 28 & 2.1 & 12 & 318 & 2.3 \\
\hline 30 & Oct. 9 & 110 & 92 & .8 & 14 & .04 & 56 & 33 & 20 & .0 & 287 & 30 & 1.7 & 9.5 & 287 & 2.7 \\
\hline 10 & ct. 13 & 50 & 52 & 1.0 & 14 & .04 & 56 & 32 & 31 & .0 & 295 & 33 & 1.5 & 13 & 295 & 2.7 \\
\hline - 24 & Oct & & & & & & & & & .0 & & & & & & 2.3 \\
\hline 1 & 7. 8 & 20 & 11 & .6 & 12 & .03 & 66 & 33 & 20 & .0 & 363 & 39 & 1.0 & 11 & 340 & 2.7 \\
\hline v. 9 & Nov. 18 & 40 & 32 & .8 & 7.2 & .01 & 64 & 32 & 16 & .0 & 345 & 32 & 0.5 & 12 & 310 & 1.9 \\
\hline 20 & v. 30 & & & & & & & & & .0 & & & & & & 3.2 \\
\hline & Dec. 10 & 270 & 164 & .6 & 20 & .10 & 49 & 24 & 27 & .0 & 260 & 42 & 6.0 & 12 & 266 & 4.4 \\
\hline . 11 & Dec. 20 & 160 & 94 & .6 & 16 & .22 & 55 & 27 & 13 & .0 & 252 & 37 & 4. & 7.0 & 294 & 10. \\
\hline 21 & Dec. 31 & 1. & 149 & 1.3 & 13 & .72 & 8 & 28 & & .0 & 283 & 41 & 4. & 9.0 & 296 & 9.3 \\
\hline Jan. 1 & Jan. 10 & 155 & 83 & .5 & 24 & .49 & 55 & 32 & 18 & .0 & 306 & 38 & 8. & 7.5 & 318 & 10. \\
\hline . 11 & Jan. 20 & 90 & 73 & .8 & 22 & .40 & 51 & 23 & 15 & .0 & 260 & 44 & 6. & 6.5 & 309 & 11.5 \\
\hline .21 & Jan. 31 & 225 & 99 & .4 & 23 & 2.6 & 25 & 7.6 & 7.9 & .0 & 10 & 24 & 5. & 5.5 & 184 & 15.5 \\
\hline Feb. 1 & Feb. 9 & 50 & 9.0 & .2 & 15 & .36 & 52 & 25 & 16 & .0 & 23 & 36 & 5. & 6.0 & 272 & 12. \\
\hline 11 & . 18 & 45 & 22 & .5 & 17 & .19 & & 24 & 14 & .0 & 252 & 42 & 6. & & 279 & 10.5 \\
\hline 19 & . 28 & 20 & 17 & .8 & 9.8 & .15 & 52 & 24 & 14 & .0 & 247 & 38 & 6. & 6.7 & 283 & 9.9 \\
\hline 1 & $\mathrm{Ma}$ & 30 & 28 & .9 & 10 & .16 & 57 & 25 & 8.8 & .0 & 237 & 51 & 5.0 & 8.0 & 266 & 8. \\
\hline - 11 & $\mathbf{M}$ & & & & & & & & & & & & & & & 6.5 \\
\hline 21 & 3 & 180 & 120 & .7 & 16 & .50 & 50 & 24 & 10.0 & .0 & 239 & 40 & 6. & 8.5 & 274 & 11.6 \\
\hline c. 1 & $\therefore$ & 130 & 95 & .7 & 14 & .22 & 49 & 23 & & .0 & 237 & 43 & 20 & 7.0 & 265 & 10.4 \\
\hline 11 & A & 60 & 39 & & 16 & .11 & 45 & 22 & 1 & .0 & 274 & 40 & 6. & 7. 0 & 309 & 8 \\
\hline 21 & Apr. 3 & & 60 & .8 & 10 & .61 & & 30 & & .0 & 24 & 43 & 9.2 & & 294 & 7. \\
\hline y 1 & May 10 & 120 & 80 & .7 & 12 & .11 & 53 & 27 & 10.0 & .0 & 24 & 40 & 10 & & 279 & 9.3 \\
\hline 11 & y 2 & & 100 & & 10 & .23 & & 27 & & -0 & & & 10 & & 316 & 9 . \\
\hline 21 & May 31 & & 180 & .9 & 11 & .80 & 5 & 27 & 1 & .0 & 230 & 43 & 13 & 6.3 & 295 & 9.3 \\
\hline 1 & $\mathrm{~J}$ & & 114 & & 18 & & & 2 & & .0 & 235 & 34 & 9. & & 302 & 10. \\
\hline e 11 & Jun & & 106 & .6 & 14 & & 5 & 24 & & .0 & & 3 & 9. & 5. & 298 & 11.0 \\
\hline e 21 & Jun & & 215 & .6 & 10 & & & $\overline{2}$ & & .0 & 265 & 36 & 6. & 6. & 286 & 8.9 \\
\hline July 1 & July 1 & & 4. & & 16 & & 6 & 25 & & .0 & 270 & 2 & 16 & 6. & 293 & 7. \\
\hline July 11 & July 2 & 4 & 333 & .7 & 14 & .09 & 60 & 20 & 10.0 & .0 & 229 & 28 & 6. & 5. & 259 & 10.4 \\
\hline July 21 & July 31 & 248 & 164 & .7 & 18 & .38 & 43 & 17 & 11 & .0 & 182 & 27 & 3.8 & 4. 5 & 213 & 11.1 \\
\hline Mean & 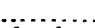 & 154 & 102 & .7 & 15 & .32 & 52 & 25 & 15 & .0 & 255 & 36 & 6.1 & 7.6 & 282 & \\
\hline Per c & & & & & & & & & & & & & & & & \\
\hline & & & & & 5. 3 & $a .2$ & 18. 4 & 8.8 & 5.3 & & & 12.7 & 2.2 & & & \\
\hline
\end{tabular}


TABLE 32.-Mineral analyses of water from Illinois River near Lasalle, Ill.

[Parts per million unless otherwise stated.]

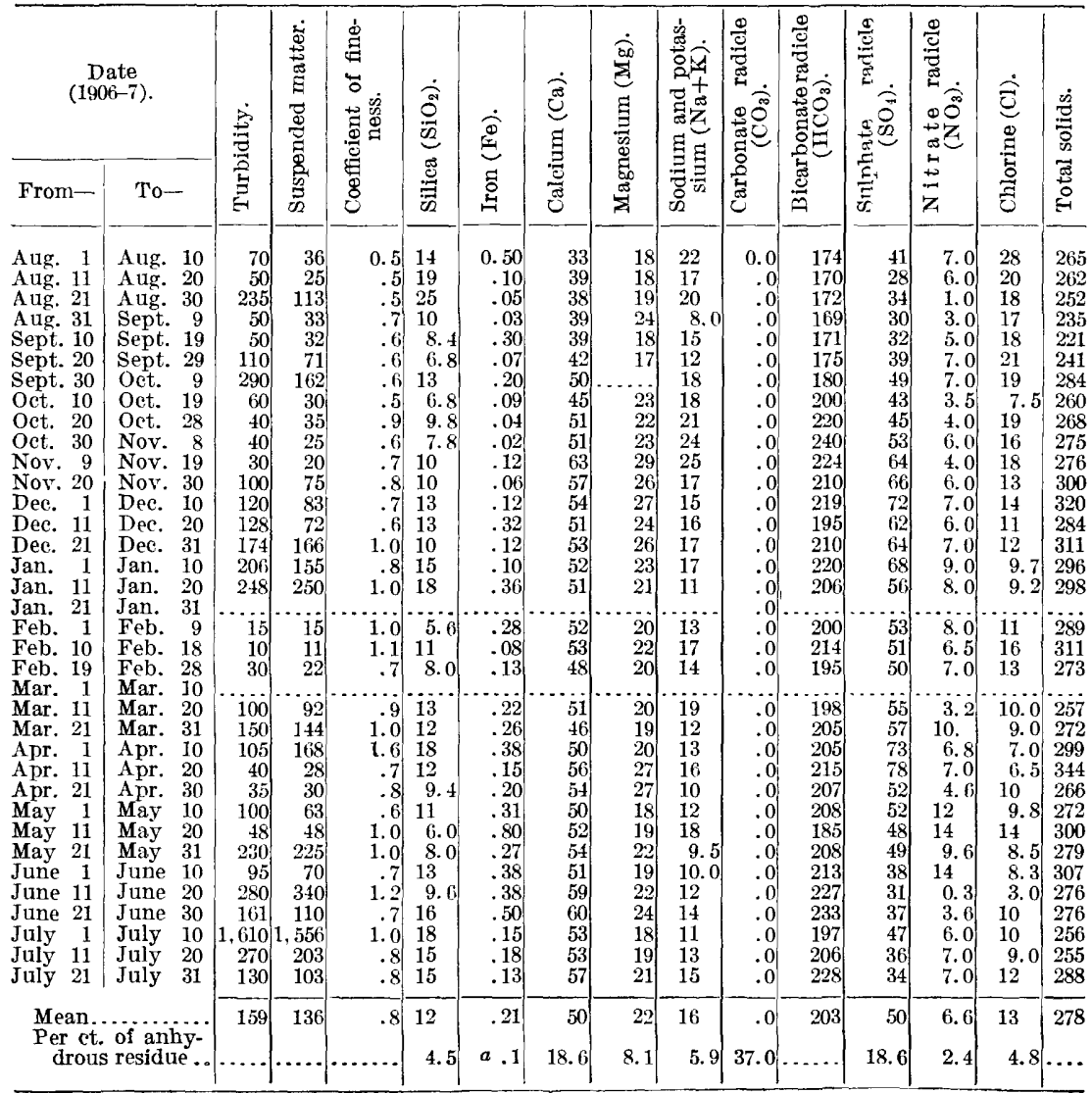

a $\mathrm{Fe}_{3} \mathrm{O}_{8}$. 
TABLE 33.--Mineral analyses of water from Illinois River rear Peoria, Ill.

[Parts per million unless otherwise stated.]

\begin{tabular}{|c|c|c|c|c|c|c|c|c|c|c|c|c|c|c|c|c|}
\hline \multicolumn{3}{|c|}{$\underset{(1906-7)}{\text { Date }}$} & \multirow{2}{*}{ 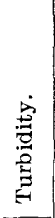 } & \multirow{2}{*}{ 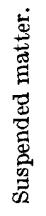 } & \multirow{2}{*}{ 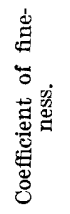 } & \multirow{2}{*}{ 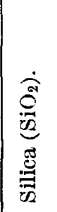 } & \multirow{2}{*}{ 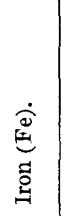 } & \multirow{2}{*}{ 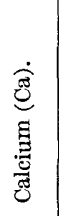 } & \multirow{2}{*}{ 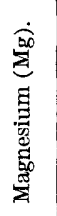 } & \multirow{2}{*}{ 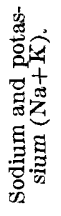 } & \multirow{2}{*}{ 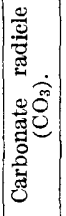 } & \multirow{2}{*}{ 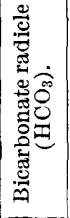 } & \multirow{2}{*}{ 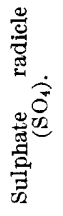 } & \multirow{2}{*}{ 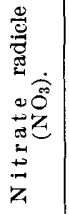 } & \multirow{2}{*}{ 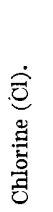 } & \multirow{2}{*}{ 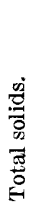 } \\
\hline From- & \multicolumn{2}{|l|}{ To- } & & & & & & & & & & & & & & \\
\hline . 1 & ug. & & 50 & 25 & 0.5 & 13 & 0.10 & 40 & 20 & 28 & 0.0 & 182 & 21 & 10.0 & 27 & 266 \\
\hline 31 & $\mathrm{~S}$ & & 60 & 29 & & 12 & & $\begin{array}{l}40 \\
42\end{array}$ & $\begin{array}{l}20 \\
20\end{array}$ & 28 & $\begin{array}{l}.0 \\
.0\end{array}$ & $\begin{array}{l}182 \\
166\end{array}$ & $\begin{array}{l}21 \\
28\end{array}$ & $\begin{array}{r}10.0 \\
4.0\end{array}$ & 20 & $\begin{array}{l}245 \\
245\end{array}$ \\
\hline 10 & pt. & 19 & 30 & 30 & 1.2 & 20 & & 45 & 18 & 23 & .0 & 18 & & & 19 & 260 \\
\hline 20 & ept. & 29 & 40 & & .5 & 6.4 & .1 & 42 & 18 & 15 & .0 & 17 & & & 20 & 222 \\
\hline 30 & oct. & 9 & 40 & 26 & .6 & 8.4 & .0 & 44 & 18 & 22 & .0 & 17 & 4 & & 22 & 249 \\
\hline 10 & Oet. & 19 & 40 & & .5 & 9.8 & .04 & & 23 & 22 & .0 & 19 & & & 20 & 279 \\
\hline ct. 20 & Oet. & 29 & 30 & 20 & 7 & 8.8 & & 4 & 19 & 21 & .0 & & & & & 233 \\
\hline bet. 30 & Nov. & 8 & 20 & 9.4 & .5 & 14 & .0 & 40 & 20 & 18 & .0 & 21 & 40 & & 20 & 264 \\
\hline Nov. 9 & Nov. & 19 & 10.0 & 11 & 1.1 & 6.4 & .0 & 4 & & 18 & .0 & 19 & 4 & & 21 & 250 \\
\hline Nov. 20 & Nov. & 30 & 20 & 17 & .8 & 8.8 & .0 & 4 & 22 & 18 & .0 & 18 & & & 18 & 2 \\
\hline Dec. 1 & Dec. & 10 & 20 & 16 & .8 & 10 & .11 & & 24 & 14 & .0 & 21 & 6 & $\ddot{8}$. & & 310 \\
\hline Dec. 11 & Dec. & 20 & 40 & 41 & 1.0 & 11 & .28 & & & 20 & .0 & 19 & & 10 & 13 & 293 \\
\hline Dec. 21 & Dec. & 31 & 15 & 13 & .9 & 17 & .14 & 5 & & 20 & .0 & 22 & & 12 & & \\
\hline Jan. 1 & Jan. & 10 & 30 & 2 & .7 & 20 & & 5 & & 21 & .0 & 23 & & 6. & 12 & 310 \\
\hline an. 11 & an. & & 80 & 40 & 5 & 21 & .64 & 5 & 22 & 14 & .0 & 207 & & 7. & 8.7 & 309 \\
\hline Jan. 21 & Jan. & 31 & 235 & 73 & .3 & 12 & & 41 & 17 & 18 & .0 & 13 & & 7. & 7.5 & 223 \\
\hline Feb. 1 & Feb. & 9 & 149 & 63 & .4 & 14 & 1.3 & 40 & & 1 & .0 & 14 & & 11 & 8.0 & 2 \\
\hline Feb. 10 & Feb. & 18 & 12 & 7. & .6 & 11 & .49 & 49 & 20 & 1 & .0 & 18 & & 11 & 11 & 275 \\
\hline Mar. 1 & Mar. & 10 & 20 & 10. & .5 & 10 & .11 & & & 19 & .0 & 18 & & 7. & $9 . \mathrm{s}$ & \\
\hline Mar. 11 & Mar. & & 45 & 36 & .8 & 14 & .22 & 5 & 2 & 18 & .0 & 20 & & 12 & 11 & 275 \\
\hline Mar. 21 & Mar. & 31 & 45 & 2 & .5 & 6.6 & .25 & 5 & 24 & 1. & .0 & & & & 9.5 & 272 \\
\hline Apr. 1 & Apr. & & & 2 & .7 & 13 & .26 & & & 19 & .0 & & & & 8. & 27 \\
\hline Apr. 11 & Apr. & 2 & 3 & 20 & 6 & 13 & .15 & & 18 & 15 & .0 & 20 & 5 & 1 & 7.5 & 304 \\
\hline pr. 21 & & & 3 & 2 & .8 & 10 & .14 & & & 1 & .0 & & & 11 & 12 & 271 \\
\hline May 1 & May & 10 & 15 & 13 & .9 & 7.4 & .16 & & & 1. & .0 & 2 & & 8. & 9.8 & 2 \\
\hline May 11 & May & & 21 & 2 & 1.0 & 10 & .28 & & & 12 & .0 & & & & & \\
\hline May 21 & May & 3. & 20 & 2 & 1.0 & 14 & .28 & & & 9. & .0 & 21 & & 9. & 10.0 & 283 \\
\hline June 1 & June & & 4 & 25 & .6 & 8.6 & .12 & 5 & & 15 & .0 & 22 & & & 8.5 & 277 \\
\hline June 11 & June & 20 & 30 & 1 & .6 & 8.0 & .32 & 61 & 2 & 16 & .0 & & & & 11 & 290 \\
\hline June 21 & June & & 6 & 31 & .5 & 8. 8 & .16 & 58 & & 15 & .0 & 21 & & & 10 & 272 \\
\hline July 1 & July & 10 & 30 & 26 & .9 & 11 & .12 & & 2 & 15 & .0 & 22 & & & 12 & 27 \\
\hline July 11 & July & & 60 & 50 & .8 & 13 & .18 & 5 & & 8.7 & 0 & 19 & & & 10 & \\
\hline July 21 & July & 31 & 23 & 19 & .8 & 14 & .1 & & & 14 & .0 & 20 & & & 8.5 & 257 \\
\hline Feb. 19 & Feb. & 27 & 25 & & & 11 & .07 & 50 & 20 & 18 & .0 & 195 & 57 & 7.0 & 13 & 275 \\
\hline \multirow{2}{*}{\multicolumn{3}{|c|}{$\begin{array}{l}\text { Mean } \\
\text { Per ct. of anhy- } \\
\text { drous residue. }\end{array}$}} & 43 & 26 & .8 & 12 & .21 & 49 & 21 & 17 & .0 & 198 & 48 & 7.8 & 13 & 271 \\
\hline & & & & & & & $a$. & 18.5 & 7.9 & & 36.7 & & 18.1 & 2.9 & & \\
\hline
\end{tabular}

a $\mathrm{Fe}_{2} \mathrm{O}_{3}$. 
TABLE 34.-Mineral analyses of water from Illinois River near Kampsville, Ill.

[Parts per million unless otherwise stated.]

\begin{tabular}{|c|c|c|c|c|c|c|c|c|c|c|c|c|c|c|c|c|}
\hline \multicolumn{2}{|c|}{$\begin{array}{c}\text { Date } \\
(1906-7)\end{array}$} & 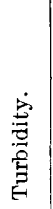 & 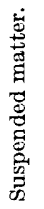 & 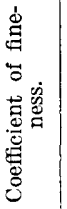 & 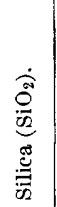 & 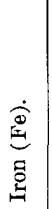 & 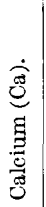 & 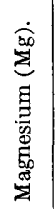 & 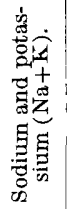 & 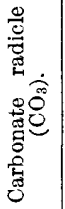 & 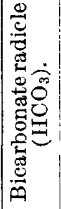 & $\mid$ & 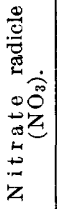 & 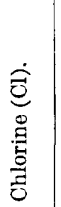 & \multicolumn{2}{|c|}{ 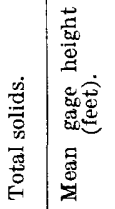 } \\
\hline g. 1 & & 105 & 72 & 0.7 & 11 & 0.20 & 46 & 21 & 34 & 0.0 & 208 & 31 & 5.0 & 24 & 278 & 14.8 \\
\hline 11 & & & 113 & & 12 & .30 & 39 & 19 & 20 & .0 & 185 & 30 & 5.4 & 22 & 262 & \\
\hline 21 & $A$ & & 120 & .5 & 11 & .05 & & 17 & & .0 & 177 & 33 & 5. 0 & & 49 & \\
\hline 31 & 9 & 147 & 89 & 6 & 8.2 & .06 & 40 & 18 & 17 & .0 & 172 & 34 & 4.0 & 20 & 236 & \\
\hline & & & 98 & .7 & 7.2 & .15 & & 20 & & .0 & & 29 & 4. & & 220 & \\
\hline 20 & 29 & 135 & 121 & .9 & 8.0 & .10 & 44. & 16 & 17 & .0 & 187 & 30 & 7.0 & 20 & 244 & \\
\hline .30 & t. 9 & 218 & 184 & .8 & 17 & .10 & 41 & 16 & 18 & .0 & 170 & 29 & 6.0 & 17 & 233 & \\
\hline 10 & 19 & & & & & & & & & & & & & & & \\
\hline 20 & 28 & 80 & 58 & .7 & 9.2 & .08 & 49 & 24 & 42 & 0 & 226 & 47 & 3.0 & 62 & 341 & \\
\hline 30 & $\mathrm{~N}$ & & 24 & .5 & 14 & .03 & 47 & 20 & & .0 & 221 & 39 & 4. & & 669 & \\
\hline 10 & 19 & 80 & 70 & .9 & 6.8 & .03 & 50 & 24 & 22 & .0 & 220 & 39 & 4. & & 274 & \\
\hline 20 & $\mathrm{~N}$ & 170 & 84 & .5 & 17 & .32 & 45 & 20 & 16 & .0 & 196 & 44 & 6. & & 246 & \\
\hline 1 & 1 & 290 & 127 & .4 & 19 & .65 & 46 & 21 & & .0 & 206 & 52 & & & 269 & \\
\hline 11 & 2 & 40 & 35 & .9 & 13 & .17 & 54 & 22 & 13 & .0 & 226 & 64 & & & & \\
\hline 21 & 31 & 4 & 51 & 1.3 & 19 & .36 & & 30 & & .0 & 65 & & 3. & 11 & 323 & \\
\hline 1. 1 & Jan. 8 & 290 & 200 & .7 & 25 & .49 & 51 & 22 & 2 & .0 & 235 & 60 & 3. & $9.5^{\prime}$ & 298 & \\
\hline . 11 & . 20 & & 260 & .6 & 16 & .64 & & 15 & 1 & .0 & 158 & & 3. & & 22 & \\
\hline 21 & 31 & & & .7 & 15 & .28 & 33 & 15 & & .0 & & & & & 21 & \\
\hline b. 1 & b. 9 & 200 & 133 & .7 & 11 & .45 & 34 & 18 & 15 & .0 & 153 & 44 & 7.0 & 5.7 & 221 & 22.0 \\
\hline 10 & 18 & & & & & & & & & & & & & & & \\
\hline 19 & 26 & 230 & 129 & .6 & 9.6 & .24 & 27 & 9. & 44 & .0 & 126 & 38 & & 34 & & 9 \\
\hline 1 & $M$ & 60 & 50 & .8 & 14 & 1.0 & 4 & 10. & & .0 & 11 & & & 4.8 & 160 & \\
\hline 11 & .2 & 7 & & .9 & 12 & .25 & 2 & 20 & 1 & .0 & & 3 & & & & \\
\hline 21 & 3 & 210 & 105 & .5 & 12 & .46 & 47 & 17 & 2 & .0 & 21 & 41 & 3. & 12 & 266 & \\
\hline 1 & 1 & 280 & 192 & .7 & 11 & .53 & & 23 & 15 & .0 & 22 & 38 & 6. & & 280 & \\
\hline 11 & 2 & 60 & 46 & .8 & 7. & .12 & & 22 & 1 & .0 & 23 & & & & 27 & \\
\hline 21 & 3 & & & .7 & & .11 & & 28 & 18 & .0 & & 5 & & 9.0 & & \\
\hline 1 & M & 33 & 295 & .9 & 13 & .16 & & 22 & 15 & .0 & 20 & 4 & 4. & 10 & & 18 \\
\hline $\mathrm{y} \quad 11$ & M & & & & 7.0 & .57 & & 24 & & .0 & & & & 18 & & \\
\hline iy 21 & May 3 & & 143 & & 8.8 & .12 & & 24 & 1 & .0 & 21 & 54 & 4. & 8.3 & 28 & 15. \\
\hline P 1 & e 1 & & & & 10 & .26 & & & & .0 & 22 & & & 7.3 & & \\
\hline June 11 & $\mathrm{Ju}$ & & 5 & & 1. & .26 & & 25 & 17 & .0 & & 35 & 2.5 & & & \\
\hline June 21 & $\mathrm{Ju}$ & & & & 1 & .32 & & & & .0 & 24 & 47 & 10 & & & \\
\hline & 1 & & & & & .12 & & & & & $23 \mathrm{~s}$ & & & & & \\
\hline July 11 & July 2 & 238 & 196 & .8 & 18 & .25 & 50 & 19 & 13 & .0 & 202 & 31 & & 10 & 260 & \\
\hline July 21 & July 31 & 74 & 64 & .9 & 15 & .34 & 54 & 20 & 11 & .0 & 219 & 27 & 1.2 & 8.0 & 242 & 19.7 \\
\hline $\begin{array}{l}\text { Mean } \\
\text { Per }\end{array}$ & & 188 & 145 & .8 & 12 & .27 & 47 & 20 & 18 & .0 & 202 & 42 & 4.3 & & 267 & \\
\hline
\end{tabular}

$a \mathrm{Fe}_{2} \mathrm{O}_{3}$. 
TABLE 35.-Mineral analyses of water from Kaskaskia River near Shelbyville, Ill.

[Parts per million unless otherwise stated.]

\begin{tabular}{|c|c|c|c|c|c|c|c|c|c|c|c|c|c|c|c|c|}
\hline \multicolumn{2}{|c|}{$\begin{array}{c}\text { Date } \\
(1906-7)\end{array}$} & \multirow{2}{*}{ 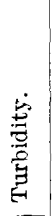 } & \multirow{2}{*}{ 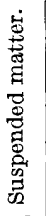 } & \multirow{2}{*}{ 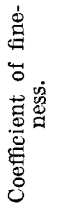 } & \multirow{2}{*}{ 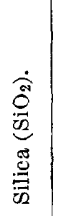 } & \multirow{2}{*}{ 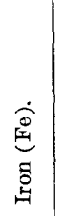 } & \multirow{2}{*}{ 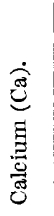 } & \multirow{2}{*}{ 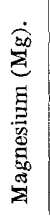 } & \multirow{2}{*}{ 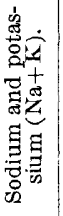 } & \multirow{2}{*}{ 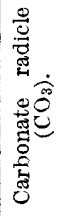 } & \multirow{2}{*}{ 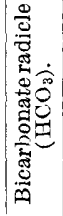 } & \multirow{2}{*}{ 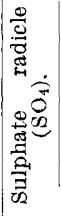 } & \multirow{2}{*}{ 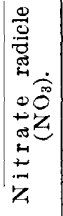 } & \multirow{2}{*}{ 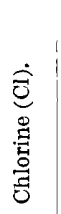 } & \multirow{2}{*}{ 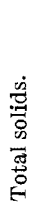 } & \multirow{2}{*}{ 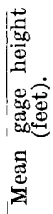 } \\
\hline From- & To- & & & & & & & & & & & & & & & \\
\hline ag. 1 & ig. 10 & 40 & 25 & 0. & 9.2 & 0.10 & 44 & 23 & 15 & 0.0 & 245 & 30 & 0.5 & 3.2 & 56 & $\varepsilon$ \\
\hline 11 & & 270 & 149 & .6 & 13 & .30 & & 23 & 15 & .0 & 233 & & & & 243 & 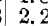 \\
\hline 21 & $A$ & 204 & 81 & .4 & 16 & .6 & & 24 & 15 & .0 & 217 & 22 & & & 836 & 2. \\
\hline 31 & & 5 & 34 & .7 & 20 & .1 & & 30 & 3.0 & .0 & 274 & & 2. & & 279 & \\
\hline 10 & & 5 & 41 & .8 & 9.6 & .3 & & 23 & 17 & .0 & & & & & 218 & 1. \\
\hline & & 4 & 28 & .7 & 9.0 & .06 & & & 24 & .0 & 289 & & 3.5 & & 886 & \\
\hline 30 & & 121 & 63 & .5 & 33 & .13 & & & 17 & .0 & 220 & & .6 & & & \\
\hline 10 & 19 & & 31 & 1. 0 & 6.4 & .0 & & 3 & 18 & .0 & 241 & & 1.2 & & 252 & 1. \\
\hline 20 & 2 & 2 & 19 & 1.0 & 14 & .0 & & 28 & 19 & .0 & 33 & & .2 & & 301 & \\
\hline 30 & 6 & 2 & 13 & .6 & 13 & .0 & & & 23 & .0 & 35 & & .3 & & & \\
\hline 10 & & 3 & 15 & .5 & 8.8 & .10 & & & 14 & .0 & 34 & & .6 & & 334 & \\
\hline 20 & 1 & 195 & 84 & .4 & 23 & .04 & & 29 & 15 & .0 & 27 & & 3.0 & & 273 & \\
\hline . 1 & - 1 & 10 & 102 & 1.0 & 17 & .24 & & & 13 & .0 & 26 & & 7.0 & & 268 & \\
\hline 11 & 2 & 4 & 45 & 1.1 & 18 & .2 & & & 14 & .0 & 267 & 33 & 8. & & 285 & \\
\hline 21 & 31 & 30 & 43 & 1.4 & 12 & .24 & 53 & 26 & 15 & .0 & 293 & 42 & 10 & 5.5 & 296 & 6. \\
\hline & 1 & & & & & & & & & & & & & & & \\
\hline . 11 & . 2 & 194 & 100 & .5 & 25 & 1.0 & 42 & 19 & 10 & .0 & 207 & 42 & 5.5 & 4.0 & 258 & \\
\hline . 22 & . 3 & 22 & 101 & .5 & 14 & .36 & & 16 & & .0 & 153 & 31 & 5. & & 192 & $212 . \mathrm{C}$ \\
\hline . 1 & . 9 & 20 & 27 & 1.4 & 16 & & & 2 & 1. & .0 & 271 & 37 & 10 & & 298 & \\
\hline . 10 & 18 & 25 & 29 & 1.2 & 13 & .13 & & 2 & & .0 & 280 & 40 & 9.0 & & 304 & 4. \\
\hline 19 & $\mathrm{~F}$ & & & & 14 & .09 & & & 1 & .0 & 280 & & & & & 4 \\
\hline Mar. 1 & 1 & 100 & & .9 & 17 & .19 & & 2 & & .0 & 237 & 38 & & & 292 & 5. \\
\hline 11 & $N$ & & & 3 & 19 & .78 & & & & .0 & 19 & & & & 267 & 9 \\
\hline 21 & 3 & 50 & & & 17 & .17 & & & 1 & .0 & 260 & 40 & & & 281 & 5. \\
\hline 1 & A & & & & 16 & .1 & & & 10 & .0 & 270 & & & & 282 & 4.5 \\
\hline 11 & .20 & 8 & 13 & 1.6 & 17 & .15 & & 19 & & .0 & 257 & 40 & 9.0 & 3.5 & 282 & 3 \\
\hline 21 & 3 & & & & & & & & & & & & & & & \\
\hline 1 & 1 & 30. & 27 & .9 & 16 & .12 & 54 & 20 & 8.4 & .0 & 257 & 35 & 12 & 3.8 & 290 & 04.0 \\
\hline 11 & & & & & & & & & & & & & & & & \\
\hline 21 & 1 & & 270 & 1.0 & 14 & .21 & & 28 & 13 & .0 & 276 & 39 & & & 303 & \\
\hline e 1 & e 1 & & 84 & & 14 & .34 & & 23 & 9.1 & .0 & 225 & 28 & 12 & & 264 & \\
\hline e 11 & 2 & & & & & & & & & .0 & & & & & 313 & \\
\hline June 21 & June 30 & 303 & 377 & 1.2 & 15 & .21 & & & 7. & .0 & 280 & & 8. & & $27^{\circ}$ & 24 \\
\hline July 1 & July 10 & & 38 & & 15 & 1 & & 2 & 9. & .0 & 304 & 34 & 2.0 & 6.0 & 315 & \\
\hline July 11 & $\mathrm{Ju}$ & & 392 & .9 & 18 & .3 & & & 10 & .0 & 258 & 30 & 16 & & 274 & 4. \\
\hline July 21 & July 31 & & 208 & .8 & 19 & .27 & & & 14 & .0 & 268 & 28 & $\begin{array}{l}3.0 \\
\end{array}$ & 4.5 & 284 & \begin{tabular}{l|l|l}
4 & 5.4
\end{tabular} \\
\hline & & 110 & 84 & .9 & 16 & .23 & 53 & 26 & 13 & .0 & 262 & 34 & 6.9 & 5.6 & 279 & \\
\hline & & & & & & & & & & & & & & & & \\
\hline
\end{tabular}


TABLE 36.-Mineral analyses of water from Kaskaskia River near Carlyle, Ill.

[Parts per million unless otherwise stated.]

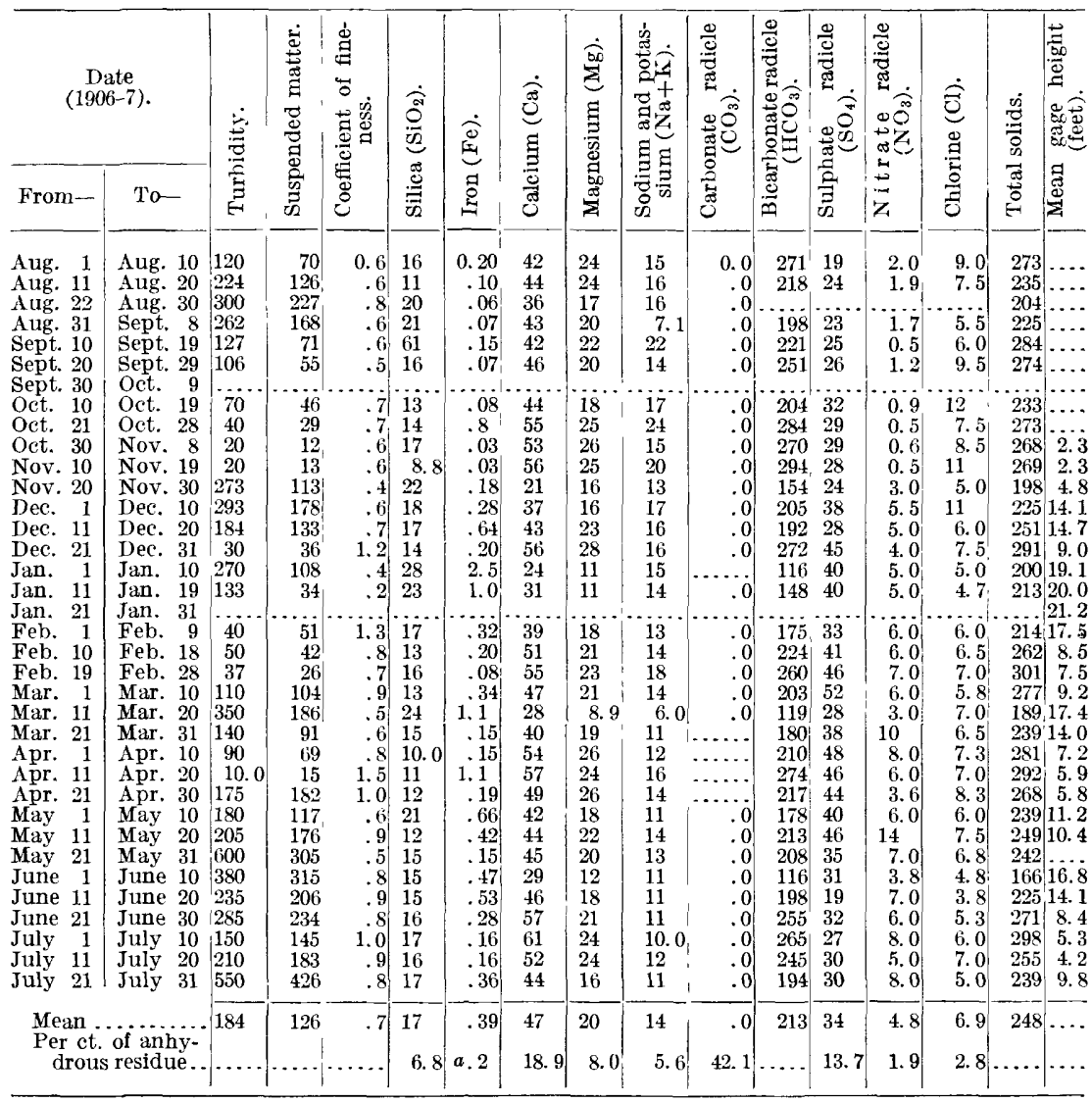


TABLE 37.- Mineral analyses of water from Muddy River near Murphysboro, Ill.

[Parts per million unless otherwise stated.]

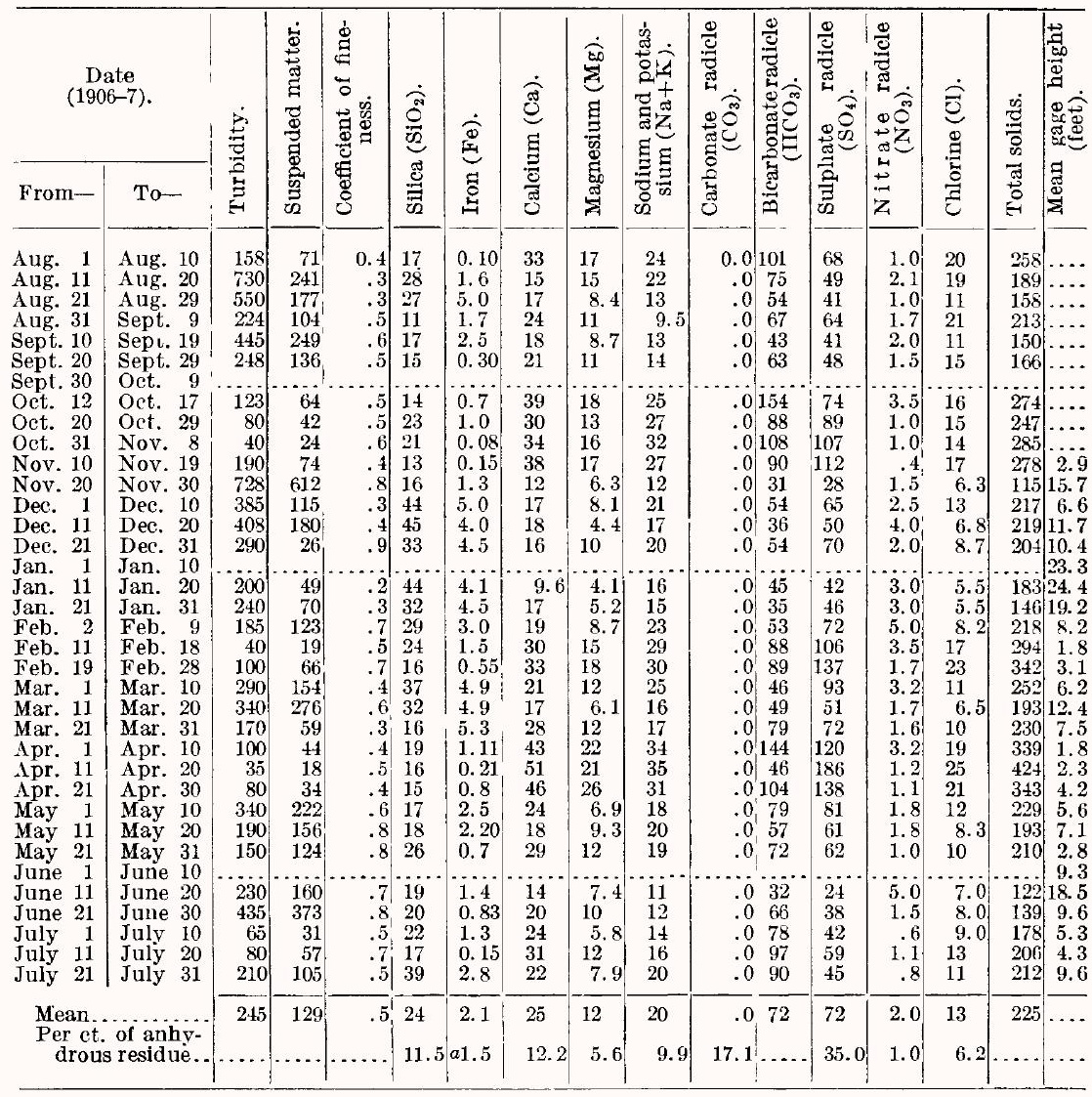

$a \mathrm{Fe}_{2} \mathrm{O}_{3}$. 
TabLe 38.-Mineral analyses of water from Mississippi River near Moline, Ill.

[Parts per million unless otherwise stated.]

\begin{tabular}{|c|c|c|c|c|c|c|c|c|c|c|c|c|c|c|c|c|}
\hline \multicolumn{2}{|c|}{$\begin{array}{c}\text { Date } \\
(1906-7) \\
\$ \neq 07\end{array}$} & \multirow{2}{*}{ 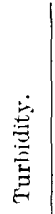 } & \multirow{2}{*}{ 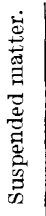 } & \multirow{2}{*}{ 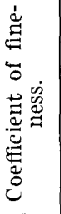 } & \multirow{2}{*}{ 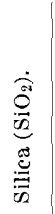 } & \multirow{2}{*}{ 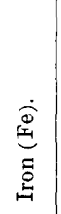 } & \multirow{2}{*}{ 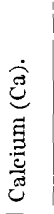 } & \multirow{2}{*}{ 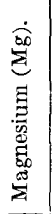 } & \multirow{2}{*}{ 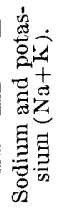 } & \multirow{2}{*}{ 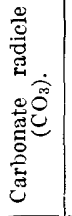 } & \multirow{2}{*}{ 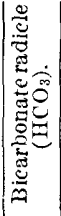 } & \multirow{2}{*}{ 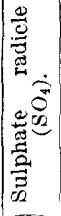 } & \multirow{2}{*}{ 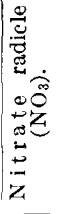 } & \multirow{2}{*}{ 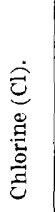 } & \multirow{2}{*}{ 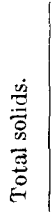 } & \multirow{2}{*}{ 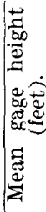 } \\
\hline From- & To- & & & & & & & & & & & & & & & \\
\hline b. 1 & & 15 & 14 & 0.9 & 29 & 32 & & 19 & 13 & 0.0 & 203 & 25 & 1 & 1. & 作 & \\
\hline 10 & & 20 & 21 & & & & & 18 & & & & $2 y^{\prime}$ & & & & \\
\hline 19 & $\mathrm{I}$ & & $1 t$ & 6 & 11 & 20 & & 13 & 11 & .0 & & & & & & \\
\hline . 1 & M & 65 & 59 & .9 & 15 & & & 1 & 1 & .0 & & & & & & \\
\hline 11 & 20 & 60 & 50 & .8 & 18 & .38 & & 12 & 11 & .0 & & & & & & \\
\hline 21 & 31 & 150 & 116 & .8 & 18 & .39 & 32 & 8. & 18 & .0 & 151 & 23 & & 4.0 & 168 & \\
\hline - 1 & & & & & & $\cdots$ & & & & & & & & & & \\
\hline 11 & & 55 & 52 & .9 & 11 & $.24_{1}$ & 20 & 10.0 & 11 & .0 & 91 & 24 & & & 124 & \\
\hline 21 & & & & 1.0 & & & 24 & 11 & 7. & .0 & & & & & & \\
\hline y 1 & 10 & 20 & 14 & .7 & 18 & 24 & & 8.2 & 8.7 & .0 & 12 & 2 & & & 152 & \\
\hline 11 & 2 & & & & 12 & 8 & 27 & 9.8 & 11 & .0 & 13 & 2 & & & 156 & \\
\hline 21 & 3 & & & & 1 & & & 1 & & .0 & 11 & & & & & \\
\hline 1 & 1 & 9 & & .8 & 1. & .3 & & 1 & 11 & .0 & & & & & 17 & \\
\hline 11 & & & & & & & & 1 & & .0 & & & & & & \\
\hline 21 & $\mathbf{J}$ & & & & 1. & & & 1. & & .0 & & & & & & \\
\hline 1 & $y$ & & & 1.0 & & & & & & .0 & & & & & & \\
\hline ly 11 & $y:$ & $37:$ & 28 & .8 & 15 & & & 1. & & .0 & & & & & 212 & \\
\hline July 21 & July 31 & 350 & 295 & .8 & 22 & & & 16 & & .0 & 171 & 34 & & & 208 & \\
\hline Mean. & & 117 & 106 & .9 & 16 & 0.39 & 33 & 13 & 10 & .0 & 152 & 24 & 1.8 & 3.7 & 179 & \\
\hline $\begin{array}{l}\text { Per et } \\
\text { drot }\end{array}$ & & & & & & & 3.7 & & & & & & & & & \\
\hline
\end{tabular}

a $\mathrm{Fe}_{2} \mathrm{O}_{3}$.

$28987-$ IRR $239-10-6$ 
TABLE 39.-Mineral analyses of water from Mississippi River near Quincy, Ill.

[Parts per million unless otherwise stated.]

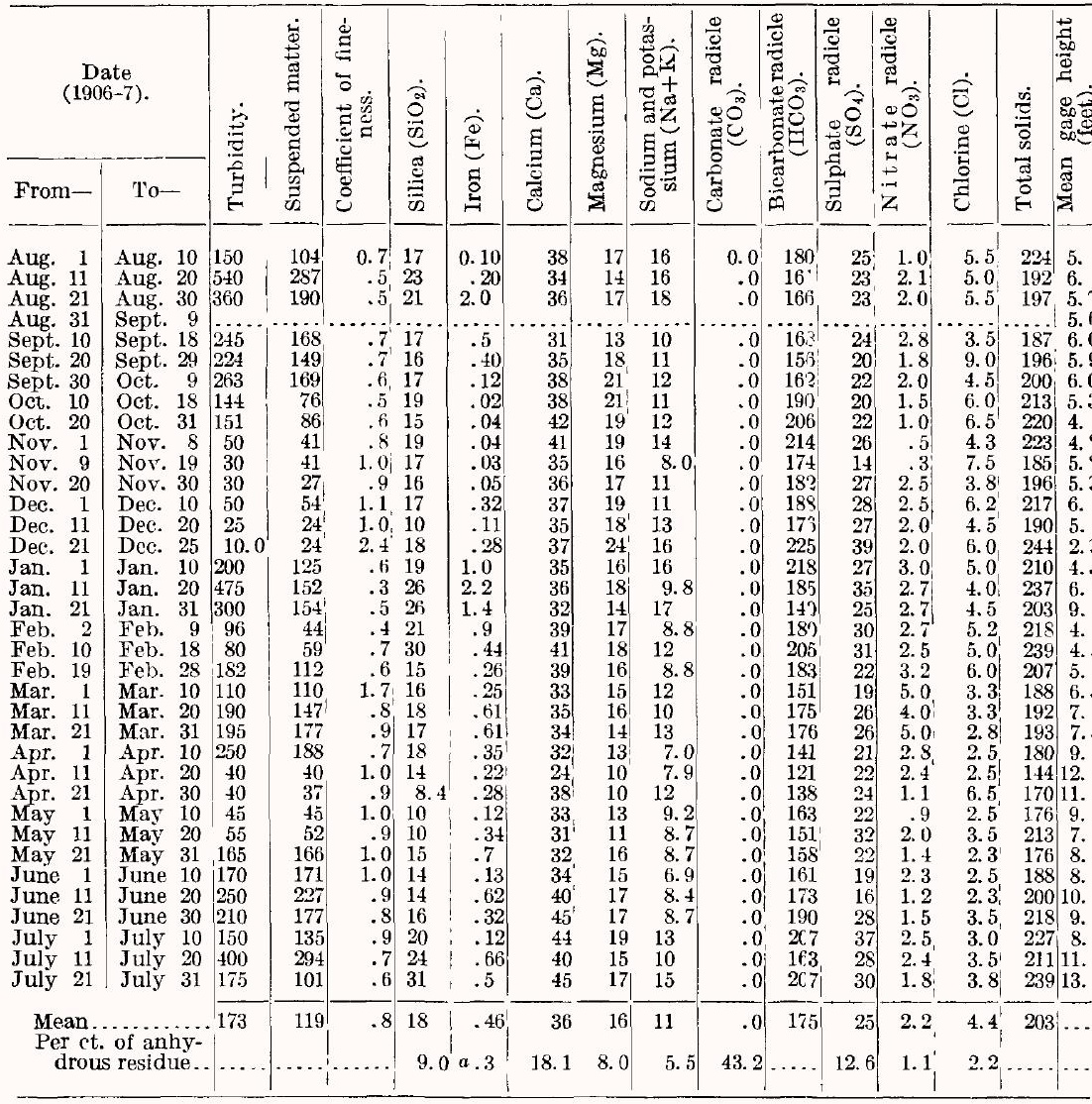

$a \mathrm{Fe}_{2} \mathrm{O}_{3}$. 
TABLE 40.-Mineral analyses of water from Mississippi River near Chester, Ill.

[Parts per million unless otherwise stated.]

\begin{tabular}{|c|c|c|c|c|c|c|c|c|c|c|c|c|c|c|c|}
\hline \multicolumn{2}{|c|}{$\begin{array}{c}\text { Date } \\
(1906-7) .\end{array}$} & 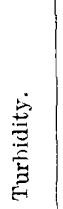 & 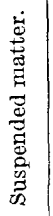 & 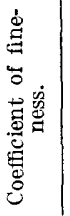 & 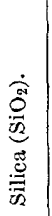 & 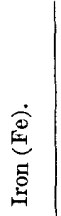 & 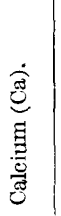 & 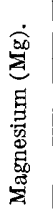 & 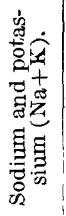 & 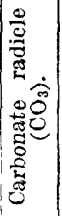 & 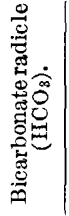 & 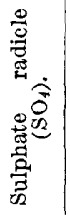 & 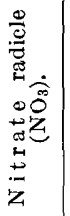 & 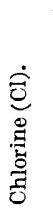 & 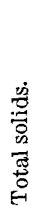 \\
\hline ug. 1 & Aug. 10 & 400 & 743 & 0.5 & 6.2 & 0.30 & 46 & 15 & 30 & 0.0 & 146 & 93 & 0.8 & 11 & 320 \\
\hline 11 & Aug. 20 & & 705 & .5 & 27 & .14 & 38 & 14 & 27 & .0 & 145 & 52 & 2.1 & 9.5 & 237 \\
\hline 21 & ug. 30 & 1,875 & 857 & .4 & 33 & .30 & 40 & 16 & 17 & .0 & 145 & 47 & 2. & 10.0 & 245 \\
\hline 31 & Sept. 9 & 1,650 & 929 & .6 & 16 & .04 & 39 & 13 & 20 & . 0 & 161 & 55 & 2.5 & 12 & 256 \\
\hline .11 & Sept. 19 & 840 & 560 & .7 & 24 & .25 & 40 & 17 & 26 & .0 & 164 & & & & 248 \\
\hline .20 & Sept. 29 & 9801 & 1,042 & 1.1 & 19 & .16 & 47 & 17 & 19 & .0 & & & & 16 & 260 \\
\hline 30 & Oct. 9 & 766 & 615 & .8 & 16 & .05 & 39 & 17 & 24 & .0 & 15 & 4 & & 11 & 228 \\
\hline 10 & Oct. 19 & 1,100 & 733 & .7 & 19 & .08 & 46 & 21 & 24 & .0 & 19 & & & 10 & 266 \\
\hline 22 & Oct. 31 & 530 & 290 & .5 & 22 & .0 & 53 & 22 & 25 & .0 & 23 & & & & $30 €$ \\
\hline 1 & Nov. 9 & 54 & $3 \pi$ & .7 & 22 & .02 & 52 & 19 & 28 & .0 & 21 & & & 15 & 316 \\
\hline 15 & Nov. 19 & 71 & 498 & .7 & 24 & .04 & 53 & 23 & 22 & .0 & 200 & & & 13 & 310 \\
\hline .20 & Nov. 28 & 634 & 440 & .7 & 19 & .20 & 42 & 17 & 15 & .0 & 18 & 5 & & 10 & 254 \\
\hline 1 & ec. 10 & 29 & 228 & .8 & 20 & & 43 & 19 & 15 & .0 & & & & 10 & 265 \\
\hline 11 & Dec. 20 & 22 & 254 & 1.2 & 17 & 1.30 & 46 & 20 & 16 & .0 & is & 5 & & 9.5 & 271 \\
\hline 22 & ec, 31 & & 151 & .8 & 15 & & 52 & & 24 & .0 & & & & 11 & 301 \\
\hline a. 1 & Jan. 10 & 32 & 235 & .7 & 20 & .56 & 43 & 18 & 16 & .0 & 205 & & & 10 & 271 \\
\hline . 11 & Jan. 19 & 45 & 355 & .8 & 20 & & 39 & 15 & 18 & .0 & 175 & 5 & 2. & 7.0 & 260 \\
\hline 21 & Jan. 31 & & 561 & .7 & 35 & & 35 & 10.0 & & .0 & 1. & & & & 222 \\
\hline 1 & Feh. 9 & 3 & 213 & .7 & 21 & 1.2 & 3 & 13 & 22 & .0 & 14 & 3 & 7. & 6.2 & 21 \\
\hline 10 & h. 18 & & 132 & .7 & 23 & & & 17 & & .0 & & & & 12 & 277 \\
\hline 21 & Feb. 28 & 58 & 496 & .8 & 24 & .33 & 47 & 16 & 2 & .0 & 18 & 6 & 4. & 12 & 304 \\
\hline . 1 & Mar. 10 & 580 & 621 & 1.1 & 21 & .35 & 4 & 17 & 26 & .0 & 16 & & & 7.5 & 266 \\
\hline 11 & Mar. 20 & 390 & 274 & .7 & 34 & .45 & 4 & 13 & & .0 & 14 & & & 18 & 257 \\
\hline 21 & Mar. 31 & 80 & 649 & .7 & 19 & .2 & 3 & 13 & 19 & .0 & 16 & & & 5.8 & 238 \\
\hline 21 & Apr. 30 & 445 & 280 & 6 & 20 & 1.2 & 47 & 20 & 12 & .0 & 16 & & & 5.0 & 256 \\
\hline 1 & June 10 &, 000 & 1,788 & .8 & 23 & .13 & 44 & 16 & 14 & & 156 & 64 & 2.4 & 7.0 & 284 \\
\hline e 11 & June 20 & & & & & & & & & & & & & & \\
\hline June 21 & June 30 & 300 & 1,455 & 1. 1 & 22 & .41 & 59 & 16 & 24 & .0 & 17 & 66 & 2. & 6.5 & 296 \\
\hline July 1 & July 10 & 1,320 & 1,277 & 1.0 & 2 & & & 14 & & .0 & & & & 7. & 294 \\
\hline July 11 & July 20 & 2,300 & 1,807 & .8 & 25 & .18 & 50 & 17 & 13 & .0 & 170 & 8 & & 7. & 304 \\
\hline July 21 & July 31 & 634 & 482 & .8 & 24 & .14 & 47 & 14 & 21 & .0 & 166 & 54 & 5.2 & 7.5 & 250 \\
\hline $\begin{array}{l}\text { Mean. } \\
\text { Per ct }\end{array}$ & anhy- & 858 & 634 & .8 & $\begin{array}{l}22 \\
8.5\end{array}$ & $\begin{array}{r}.39 \\
\text { c. } 2\end{array}$ & $\begin{array}{r}44 \\
17.1\end{array}$ & 16 & 21 & .0 & 174 & $\begin{array}{r}56 \\
21.8\end{array}$ & 2.7 & 9.8 & 269 \\
\hline
\end{tabular}

a $\mathrm{Fe}_{2} \mathrm{O}_{3}$. 
TABLe 41.-Mineral analyses of water from Vermilion River near Danville, Ill.

[Parts per million unless otherwise stated.]

\begin{tabular}{|c|c|c|c|c|c|c|c|c|c|c|c|c|c|c|c|}
\hline & & & 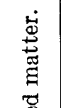 & 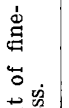 & & & ๑ొ & 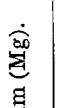 & 离 & 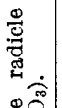 & 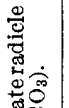 & 莺 & 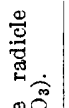 & $\dot{\vec{\theta}}$ & \\
\hline From- & To- & $\stackrel{5}{5}$ & $\underset{0}{3}$ & ठั. & 号 & 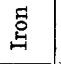 & 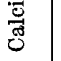 & 丞 & 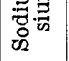 & రే & 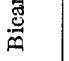 & $\begin{array}{c}\vec{B} \\
\vec{B}\end{array}$ & \pm & 岂 & \\
\hline Lug. 2 & Aug. 10 & 135 & 54 & 0.4 & 20 & 0.40 & 48 & 31 & 27 & 0.0 & 272 & 39 & 0.7 & 5.7 & 299 \\
\hline Aug. 11 & Aug. 20 & 300 & 147 & .5 & 18 & .5 & 38 & 24 & 11 & $\begin{array}{l}.0 \\
\end{array}$ & 193 & 27 & 2.7 & 3.2 & $\begin{array}{l}295 \\
216\end{array}$ \\
\hline Aug. 22 & Aug. 30 & 425 & 201 & .5 & 19 & .20 & 36 & 15 & 15 & .0 & 163 & 25 & 4.5 & 4.5 & 222 \\
\hline Aug. 31 & Sept. 9 & 117 & 59 & .5 & 15 & .10 & 56 & 28 & 15 & .0 & 241 & 36 & 3.0 & 5.0 & 282 \\
\hline t. 10 & Sept. 19 & 50 & 38 & .8 & 13 & .30 & 44 & 28 & 8.7 & .0 & 285 & 38 & .8 & 5.0 & 267 \\
\hline pt. 20 & Sept. 29 & 142 & 68 & .5 & 20 & .12 & 49 & 24 & 15 & .0 & 282 & 32 & 1.8 & 7.0 & 264 \\
\hline t. 30 & Oct. 9 & 90 & 44 & .5 & 11 & .07 & 52 & 26 & 18 & .0 & 270 & 36 & 1.2 & 5.0 & 275 \\
\hline Oct. 10 & Oct. 19 & & & & & & & & & & & & & & \\
\hline Oct. 20 & Oct. 29 & 20 & 18 & .9 & 12 & .04 & 59 & 36 & 23 & .0 & 326 & 41 & .6 & 7.5 & 322 \\
\hline 30 & Nov. 8 & 10.0 & 5.2 & .5 & 13 & .10 & 63 & 36 & 20 & .0 & 350 & 46 & .3 & 6.5 & 342 \\
\hline 6. 9 & Nov. 19 & 20 & 7.8 & .4 & 6.2 & .03 & 60 & 36 & 21 & .0 & 330 & 44 & & 7.5 & 318 \\
\hline .20 & Nov. 30 & 161 & 155 & 1.0 & 16 & .05 & 53 & 25 & 10.0 & .0 & 220 & 46 & 8.0 & 3.5 & 279 \\
\hline Dec. 1 & Dec. 10 & 125 & 78 & .6 & 21 & .06 & 5 & 26 & 12 & .0 & 254 & 47 & 14 & 4.2 & 302 \\
\hline Dec. 11 & Dec. 20 & 50 & 61 & 1. 2 & 12 & .17 & 5 & 27 & 8.0 & .0 & 236 & 42 & 16 & 4.8 & 301 \\
\hline Dec. 21 & Dec. 31 & 40 & 47 & 1.2 & 10.0 & .24 & 5 & 28 & 14 & .0 & 275 & 46 & 12 & 4.5 & 314 \\
\hline Jan. 1 & Jan. 10 & 270 & 258 & 1.0 & 19 & .37 & 3 & 22 & 14 & .0 & 189 & 67 & 12 & 4.7 & 254 \\
\hline Jan. 11 & Jan. 19 & 296 & 255 & .9 & 17 & .6 & 4 & 18 & 13 & .0 & 190 & 47 & 5.5 & 3.0 & 245 \\
\hline Jan. 21 & Jan. & 90 & 57 & .6 & 20 & 1.1 & 5 & 22 & 13 & .0 & 189 & 41 & 16 & 5.0 & 263 \\
\hline Feb. 1 & Feb. 9 & 10.0 & 6.0 & .6 & 15 & .16 & 6 & 27 & 13 & .0 & 265 & 47 & 16 & 5.2 & 330 \\
\hline Feb. 10 & Feb. 18 & 45 & 21 & .5 & 18 & .09 & 5 & 23 & 14 & .0 & 240 & 55 & 12 & 5.0 & 316 \\
\hline Feb. 20 & Feb. 28 & 10.0 & 12 & 1.2 & 8.4 & .13 & 5 & 24 & 14 & .0 & 247 & 50 & 16 & & 299 \\
\hline Mar. 1 & Mar. 10 & 7.0 & 8.6 & 1.2 & 11 & .13 & 4 & 23 & 14 & .0 & 243 & 39 & 8.0 & 3.8 & 279 \\
\hline Mar. 11 & Mar. 20 & 230 & 164 & .7 & 15 & .70 & & 20 & 13 & .0 & 180 & 50 & 12 & 3. & 256 \\
\hline Mar. 21 & Mar. 31 & 160 & 45 & .3 & 15 & .54 & 4 & 22 & 9.3 & .0 & 207 & 48 & 24 & 4.8 & 250 \\
\hline Apr. 1 & Apr. 10 & 25 & 18 & .7 & 14 & .18 & 5 & 25 & 9. & .0 & 236 & 44 & 24 & & 266 \\
\hline Apr. 11 & Apr. 20 & 5.0 & $\begin{array}{r}4.4 \\
\end{array}$ & .9 & 8.6 & .23 & 54 & 21 & 10.0 & .0 & 242 & 45 & 19 & 2.5 & 264 \\
\hline Apr. 21 & Apr. 30 & 19 & 18 & 1.0 & 4. 7 & 1.3 & & 35 & 8. & .0 & 247 & 52 & 11 & & 295 \\
\hline May 1 & May 10 & 45 & 25 & .6 & 18 & .26 & 50 & 18 & 9. & .0 & 227 & 45 & 24 & 3. & 274 \\
\hline May 11 & May 20 & 25 & 22 & .9 & 9.2 & .15 & 56 & 24 & 9. & .0 & 243 & 40 & 24 & 3. & 288 \\
\hline May 21 & & 35 & 36 & 1.0 & $11^{2}$ & .15 & & & & .0 & 239 & 44 & 2 & & 276 \\
\hline June 1 & June 10 & 330 & 251 & .8 & 13 & .18 & 50 & 26 & 8. & .0 & 175 & 37 & 20 & 4.2 & 230 \\
\hline June 11 & June 20 & 65 & 56 & .9 & 11 & & & & 8. & .0 & 250 & 42 & 16 & 4. & 304 \\
\hline June 21 & June 30 & 100 & 29 & .3 & 14 & .57 & & 2 & 8. & .0 & 24 & 3 & 10.0 & & 258 \\
\hline July 1 & July 10 & 70 & 68 & 1.0 & 17 & .25 & 6 & 2 & 6. & .0 & 26 & & 16 & & 301 \\
\hline July 11 & July 20 & 460 & 487 & 1.1 & 13 & .24 & 6 & 2 & 8.2 & .0 & 221 & 34 & 1 & 3.3 & 290 \\
\hline July 21 & July 31 & 55 & 48 & .9 & 17 & .23 & 64 & 25 & 8.9 & .0 & 265 & 35 & 24 & 4.0 & 285 \\
\hline Mean & & 115 & 82 & .8 & 14 & .29 & 54 & 25 & 13 & .0 & 243 & 42 & 12 & 4.5 & 281 \\
\hline Per c & & & & & & & & 8.8 & & & & 14.7 & 4.2 & & \\
\hline
\end{tabular}

a $\mathrm{Fe}_{2} \mathrm{O}_{3}$. 
TABLE 42.-Mineral analyses of water from Embarrass River near Charleston, Ill.

[Parts per million unless otherwise stated.]

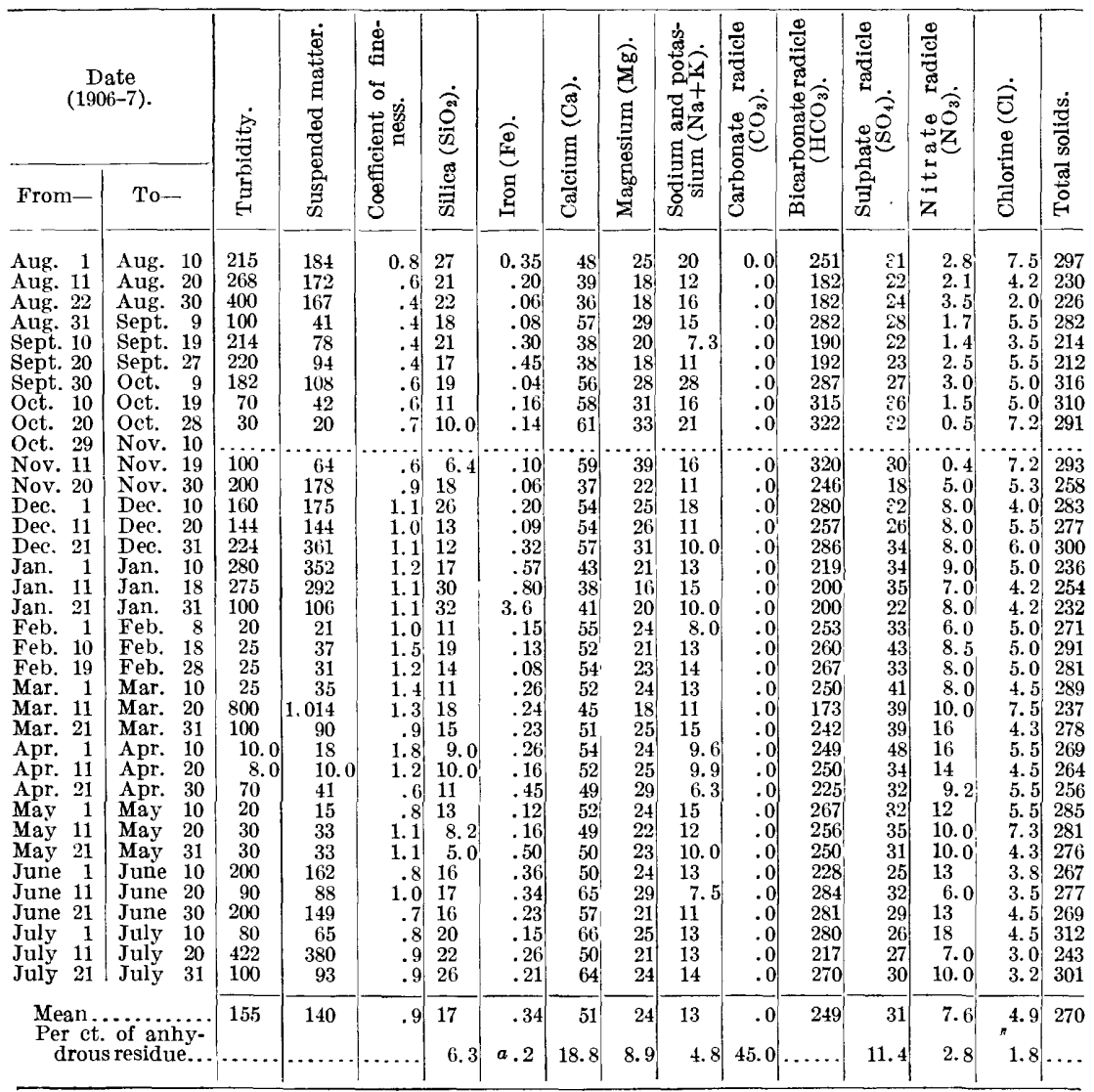

a $\mathrm{Fe}_{2} \mathrm{O}_{3}$. 
TABLE 43.--Mineral analyses of water from Embarrass River necr Lawrenceville, Ill.

[Parts per million unless otherwise stated.]

\begin{tabular}{|c|c|c|c|c|c|c|c|c|c|c|c|c|c|c|c|c|}
\hline \multicolumn{3}{|c|}{$\underset{(1906-7)}{\text { Date }}$} & \multirow{2}{*}{ 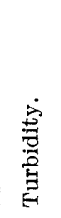 } & \multirow{2}{*}{ 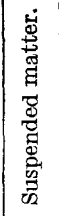 } & \multirow{2}{*}{ 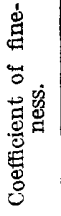 } & \multirow{2}{*}{ 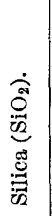 } & \multirow{2}{*}{ 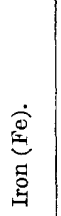 } & \multirow{2}{*}{ 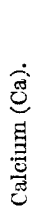 } & \multirow{2}{*}{ 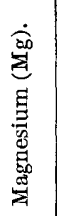 } & \multirow{2}{*}{ 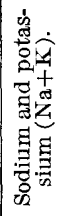 } & \multirow{2}{*}{ 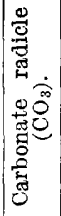 } & \multirow{2}{*}{ 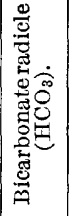 } & \multirow{2}{*}{ 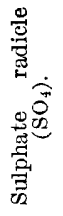 } & \multirow{2}{*}{ 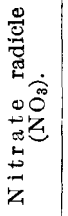 } & \multirow{2}{*}{ 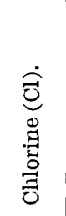 } & \multirow{2}{*}{ 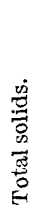 } \\
\hline From- & \multicolumn{2}{|c|}{ To- } & & & & & & & & & & & & & & \\
\hline ug. 1 & g. & & 280 & 52 & 0.5 & 24 & 30 & 42 & 22 & 29 & 0.0 & 207 & 33 & 1.2 & 26 & 278 \\
\hline 11 & & 2 & 220 & 111 & .5 & 15 & .14 & 33 & 18 & 18 & .0 & 150 & 23 & 2.4 & & 231 \\
\hline 21 & . & 3 & 268 & 103 & .4 & 17 & .30 & 33 & 18 & 32 & & 123 & 26 & 1.5 & 4 & 2 \\
\hline 31 & - & 16 & 148 & 89 & .6 & 15 & .20 & 42 & 22 & 19 & .0 & 205 & 24 & .8 & 26 & 251 \\
\hline 17 & & 2 & & & & - & & & & & & & & & & \\
\hline t. 27 & & 1 & & & & & & & 19 & & & & & & & \\
\hline t. 13 & Oet. & 19 & 20 & 19 & 1.0 & 18 & .08 & 59 & 27 & 49 & .0 & 274 & 45 & 7.0 & 64 & 426 \\
\hline t. 20 & Oct. & 29 & 20 & 15 & .8 & 16 & .10 & 55 & 25 & & .0 & 270 & 36 & .3 & 61 & 371 \\
\hline 30 & Nov. & 8 & 20 & 8.0 & .4 & 11 & .10 & 60 & 34 & 87 & .0 & 305 & 49 & .2 & 114 & $47^{\circ}$ \\
\hline จ. 9 & Nov. & 18 & 20 & 7.4 &. \pm & 16 & .05 & 72 & 31 & 48 & .0 & 335 & 50 & 5.5 & 75 & 468 \\
\hline ov. 20 & Nov. & 30 & 220 & 98 & .5 & 15 & .20 & 66 & & 55 & .0 & 229 & 64 & .3 & 88 & 45 \\
\hline $\begin{array}{l}\text { ec. } 14 \\
\text { ec. } 21\end{array}$ & Dec. & 20 & & & & & & & & & & & & & & \\
\hline Dec. 21 & ec. & 31 & 103 & 76 & .7 & 21 & .32 & 49 & 23 & & .0 & 227 & 16 & 5. 0 & 20 & 308 \\
\hline Jan. 1 & an. & 10 & & 78 & .4 & 20 & 3.7 & 19 & 8.5 & 18 & .0 & $1>0$ & 2 & 2. & 9.5 & 18 \\
\hline . 11 & & 2 & & 8 & .6 & 31 & 1.4 & 28 & 16 & 1 & .0 & 13 & & 4. & 9. & 20 \\
\hline Jan. 21 & $\mathrm{~J}$ & 31 & 159 & 50 & .3 & 25 & 1.7 & 24 & 9.5 & 1 & .0 & $1 \%$ & & 4.0 & 8.2 & 174 \\
\hline Feb. 2 & Feb. & 9 & 45 & 3 & .8 & 14 & .22 & 46 & 20 & 2 & .0 & 20 & & 2.0 & 20 & 268 \\
\hline b. 10 & Feb. & 18 & 12 & 13 & 1.1 & 1 & .13 & & 22 & 2 & .0 & 2 & & 6. & & \\
\hline Feb. 19 & Feb. & 28 & 8.0 & 11 & 1.2 & 18 & .07 & 5 & 24 & & .0 & 21 & & 6. & & 34 \\
\hline 1 & Mar. & & 50 & 45 & .9 & 1 & .15 & & & & .0 & & & 4. & & 3 \\
\hline Mar. 11 & Mar. & 2 & 280 & 177 & .6 & 2 & 2.2 & 26 & 10.0 & 1 & .0 & 11 & & 9.2 & 14 & 19 \\
\hline 21 & Mar. & & 120 & 54 & .4 & 19 & .78 & 44 & 16 & 19 & .0 & 198 & 39 & 14 & 16 & 27 \\
\hline เ. 1 & Apr. & & & & & & & & & & & & & & & \\
\hline 11 & Ap & & 1 & 1 & .9 & 13 & .1 & 55 & 26 & & .0 & 24 & & & & 32 \\
\hline pr. 21 & & & 11 & 54 & .5 & 1 & .3 & & 24 & & .0 & & & & & \\
\hline May 1 & May & 1 & 210 & 109 & .5 & 1 & .6 & & 12 & & .0 & 1. & & & & 23 \\
\hline ay 11 & & & 80 & 44 & .6 & 1 & .1 & & 17 & & .0 & & & & & 28 \\
\hline May 21 & May & & 120 & 94 & .8 & 19 & .3 & 3 & 15 & & .0 & 1t & & & & 23 \\
\hline le 1 & June & & & 107 & .5 & 9.2 & .29 & & 9.3 & & .0 & & & & & 120 \\
\hline ne 11 & June & 2 & & 70 & .7 & 18 & .59 & 4 & 23 & & .0 & 18 & & 2 & & 25 \\
\hline June 21 & June & & & 128 & & & .9 & & & & .0 & & & & & 25 \\
\hline July 1 & July & 10 & 43 & 41 & 1.0 & 1 & .14 & & 20 & & .0 & 2 & & & & 27 \\
\hline July 11 & July & 20 & 181 & 123 & .7 & 1 & .11 & 39 & 18 & & .0 & 15 & 2 & & & 246 \\
\hline July 21 & July & 31 & (1) & 60 & .9 & 15 & .22 & 45 & 17 & 15 & .0 & 170 & 24 & 6.0 & 22 & 222 \\
\hline Mean. & & & 118 & 66 & .7 & 17 & .53 & 44 & 19 & 28 & .0 & 195 & 35 & 3.7 & 35 & 283 \\
\hline er ct & & & & & & 6.1 & $a .3$ & & 6.8 & 10.0 & 34.5 & & 12. & 1.3 & 12. & \\
\hline
\end{tabular}

$a \mathrm{Fe}_{2} \mathrm{O}_{3}$. 
TABLE 44.-Mineral analyses of water from Little Wabash River near Carmi, Ill.

[Parts per million unless otherwise stated.]

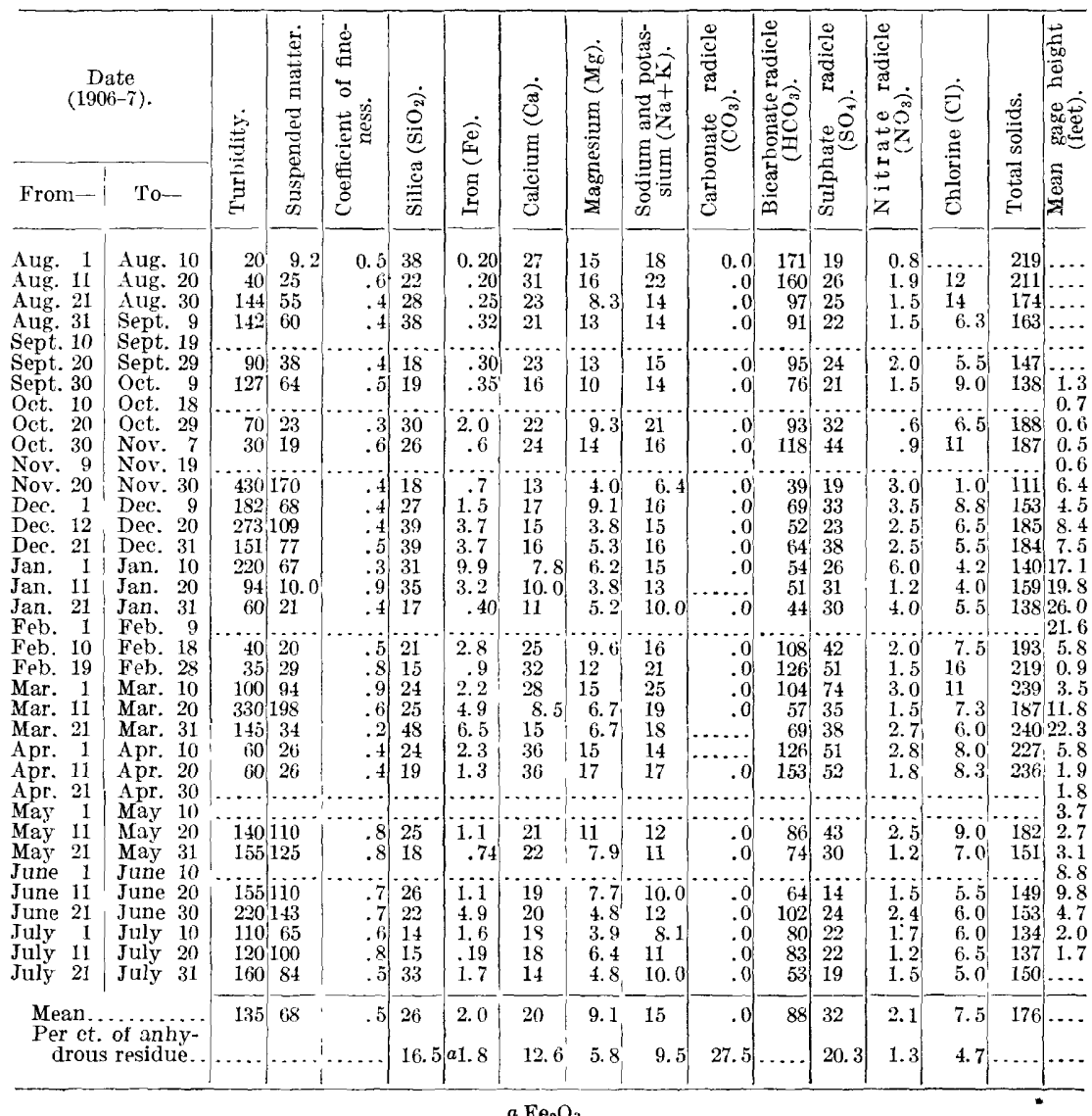


TABle 45.-Mineral analyses of water from Cache River near Mounds, Ill.

[Parts per million unless otherwise stated.]

\begin{tabular}{|c|c|c|c|c|c|c|c|c|c|c|c|c|c|c|c|c|}
\hline \multicolumn{2}{|c|}{$\begin{array}{c}\text { Date } \\
(1906-7)\end{array}$} & \multirow{2}{*}{ 㝕 } & \multirow{2}{*}{ 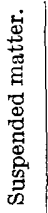 } & \multirow{2}{*}{ 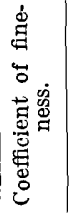 } & \multirow{2}{*}{ 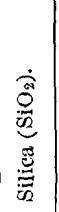 } & \multirow{2}{*}{ 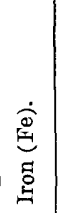 } & \multirow{2}{*}{ 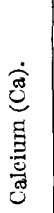 } & \multirow{2}{*}{ 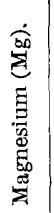 } & \multirow{2}{*}{ 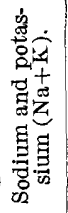 } & \multirow{2}{*}{ 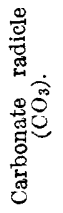 } & \multirow{2}{*}{ 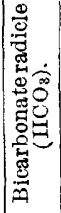 } & \multirow{2}{*}{ 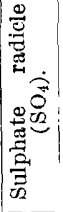 } & \multirow{2}{*}{ 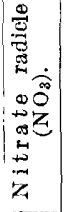 } & \multirow{2}{*}{ 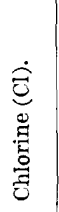 } & \multirow{2}{*}{ 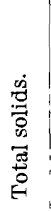 } & \multirow{2}{*}{ 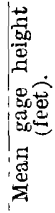 } \\
\hline From- & To- & & & & & & & & & & & & & & & \\
\hline & & & 94 & 0.4 & 4. 6 & 0.20 & 26 & 10.0 & 13 & 0.0 & 121 & 4.8 & 1.0 & 7.2 & 166 & \\
\hline 11 & & & 75 & .3 & 20 & 1.0 & 18 & 7.4 & 29 & .0 & 93 & 20 & 0.9 & 5.0 & $1+1$ & \\
\hline 21 & & 15 & 61 & .3 & 31 & .60 & 22 & 7. 0 & 38 & .0 & 90 & 35 & 1.0 & 15 & 211 & \\
\hline 31 & & & 64 & .5 & 16 & .17 & 22 & 9.1 & 20 & .0 & 94 & 14 & 1.0 & 6.5 & 139 & \\
\hline 10 & 19 & & & & & & & & & & & & & & & \\
\hline & & & & & & & & & & & & & & & & \\
\hline 0 & & & & & & & & & & & & & & & & \\
\hline 1 & ( & & & & & & & & & & & & & & & \\
\hline 20 & - 31 & 40 & 15 & .4 & 9.2 & .26 & 33 & 13 & 17 & .0 & 159 & 27 & .7 & 7.0 & 190 & 0 \\
\hline - 1 & - 8 & & 42 & 1. 0 & 22 & .19 & 42 & 8. 7 & 25 & .0 & 211 & 44 & & 19 & 284 & 4 \\
\hline 15 & 21 & 15 & & .4 & 26 & .25 & 19 & & & .0 & 108 & & 1.5 & & 244 & \\
\hline .22 & 30 & 16 & 58 & .3 & 28 & .80 & 19 & 4.5 & 37 & .0 & 85 & 35 & 2. & 14 & 229 & \\
\hline c. 1 & I & 27 & 175 & .6 & 23 & 2.8 & 9.7 & 3. 6 & 11 & .0 & 59 & 14 & & & 129 & 5 \\
\hline 11 & & & & .2 & 22 & & 9. & 3. & 7.4 & .0 & 41 & 18 & & & 126 & 6i) \\
\hline 21 & I & 5 & 15 & 3.0 & 28 & & 9. & 6. & 14 &. & 59 & 17 & & & 117 & \\
\hline 1 & & & & .3 & 3 & & 8. & & 1 & & 72 & & & & 170 & \\
\hline - 11 & $\mathrm{~J}$ & 11 & & .3 & 20 & & 12 & & 11 &. & 62 & & & & & \\
\hline 2 & . & & & .5 & 2 & & 1 & & 1 &. & 66 & 1 & & & 121 & \\
\hline - 1 & . 9 & & 3 & .8 & 2 & & 1 & & 12 & & 58 & 22 & & & 129 & \\
\hline 10 & ). 17 & & 1 & .6 & 1 & & 1 & & 11 & & 74 & 13 & & & 115 & \\
\hline 19 & I & & & .5 & 2 & 4. & & & 8.2 & & 70 & & & & 121 & \\
\hline 1 & 1 & & 36 & .4 & 3 & & 1 & 5. & 13 & . & 42 & 15 & & & 138 & \\
\hline 11 & I & & 73 & .3 & 4 & & & & 7.0 & & 57 & 9. & & & & \\
\hline 21 & 3 & & 48 & .4 & 2 & 7. & 16 & & & . & 64 & 16 & & & 119 & \\
\hline 1 & I & & & .2 & 2 & & & & & & 69 & 15 & 7. & & & \\
\hline 11 & A & & & .6 & 1 & & & & & . & 94 & 1 & & & 138 & 5. \\
\hline r. 21 & A & & 30 & .7 & & & & & o. & -1 & 96 & & 1.5 & 4. & 118 & 6 \\
\hline May 1 & May & 145 & 117 & .8 & 12 & 1.5 & 28 & 5.8 & 19 & 0 & 104 & 36 & 1.0 & 13 & & 9 \\
\hline 11 & 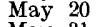 & & & & & & & & & & & & & & & \\
\hline 21 & & & 125 & 1.0 & 22 & .58 & 16 & & & & 52 & 12 & & & 92 & \\
\hline e 1 & e 1 & 19 & 78 & .4 & 11 & & 20 & & & . & 69 & 2 & & & 100 & \\
\hline 11 & $\mathrm{~J}$ & & & & & & & & & & & & & & 140 & \\
\hline e 21 & June 30 & 65 & 38 & .6 & 20 & 4.5 & 24 & 0.0 & 6. & & 85 & 11 & 8. & 4. & 131 & 116 \\
\hline July 1 & July 10 & 103 & 76 & .7 & 15 & .20 & 23 & 5. 9 & 8.8 & & 97 & 9.7 & 2.0 & 4.5 & 116 & \\
\hline uly 11 & (2, & & & & & & & & & & & & & & & \\
\hline July 21 & July 31 & 160 & 102 & .6 & 24 & 2.6 & 25 & 9.0 & 13 & . & 100 & 10.0 & .7 & 10.0 & 158 & 8.11 .6 \\
\hline Mean & & 134 & 66 & $\cdot 6$ & 22 & 2.5 & 19 & & 15 & .0 & 85 & 19 & 2.1 & 6.8 & 149 & \\
\hline & & & & & & & 14. & & 11.1 & 31.1 & & 14.0 & 1.5 & & & \\
\hline
\end{tabular}

a $\mathrm{Fe}_{2} \mathrm{O}_{3}$. 
TABLE 46.-Average quality of waters of some rivers in Illinois.

[Parts per million.]

\begin{tabular}{|c|c|c|c|c|c|c|c|c|c|c|c|c|c|c|}
\hline $\begin{array}{l}\text { Source and location of } \\
\text { sampling station. }\end{array}$ & 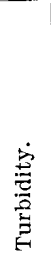 & 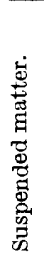 & 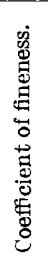 & 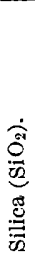 & 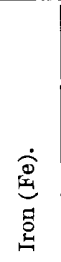 & 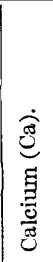 & 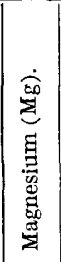 & 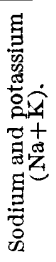 & 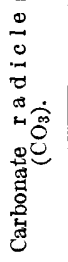 & 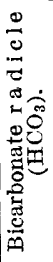 & 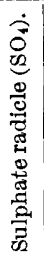 & 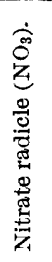 & 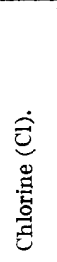 & 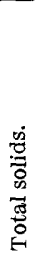 \\
\hline Reservoir, Cartter, Ill. & 72 & 33 & 0.5 & 16 & 1.9 & 9.0 & 3.6 & 8.6 & 0.0 & 34 & 16 & 2.1 & 5.2 & 92 \\
\hline Reser & 97 & 43 & .5 & 13 & .93 & 15 & 8.2 & 17 & .0 & 51 & 45 & 1. & 8.3 & 140 \\
\hline Reservoir, Cypress, Ill. & 155 & 59 & .5 & 29 & 3.7 & 18 & 7.0 & 13 & .0 & 67 & 33 & 2. & 6.8 & 165 \\
\hline Reservoir, Joppa, Ill ... & 116 & 66 & .5 & 22 & 3.5 & 10 & 4.0 & 9.0 & .0 & 43 & 19 & $1 . \overline{9}$ & 4.3 & 111 \\
\hline $\begin{array}{l}\text { Rock River, Rockford, } \\
\text { Ill............... }\end{array}$ & 134 & 92 & .7 & 15 & .44 & 45 & 25 & 10 & .0 & 252 & 22 & 4.1 & 4.6 & 250 \\
\hline $\begin{array}{l}\text { Rock River, Sterling, Ill.. } \\
\text { Kankakee River, Kanka- }\end{array}$ & 229 & 236 & 1.2 & 15 & .31 & 49 & 27 & 12 & .0 & 263 & 25 & 3.8 & 5.5 & 267 \\
\hline 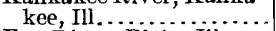 & 50 & 32 & .7 & 15 & .27 & 58 & 21 & 12 & .0 & 215 & 57 & 4.1 & 4.9 & 288 \\
\hline Fox River, Elgin, Ill..... & 34 & 23 & .7 & 12 & .15 & 51 & 30 & 11 & .0 & 268 & 38 & 2.4 & 5.2 & 290 \\
\hline Fox River, Ottawa, Ill .. & 94 & 87 & 1.2 & 11 & .20 & 60 & 32 & 14 & .0 & 275 & 61 & 4.9 & 7.9 & 335 \\
\hline 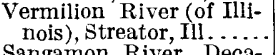 & 107 & 78 & .7 & 14 & .22 & 55 & 29 & 18 & .0 & 241 & 68 & 12 & 6.9 & 325 \\
\hline 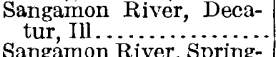 & 126 & 87 & .7 & 19 & .27 & 55 & 26 & 14 & .0 & 268 & 35 & 8.5 & 5.4 & 293 \\
\hline $\begin{array}{l}\text { Sangamon Riv } \\
\text { field IIl .... } \\
\text { Sangamon Riv }\end{array}$ & 74 & 39 & .8 & 16 & .32 & 52 & 24 & 16 & .0 & 247 & 37 & 3.4 & 7.5 & 276 \\
\hline $\begin{array}{l}\text { ion River, Chan- } \\
\text { lle, Ill ............... }\end{array}$ & 154 & 102 & .7 & 15 & .32 & 52 & 25 & 15 & .0 & 255 & 36 & 6.1 & 7.6 & 282 \\
\hline River, Lasalle, 111 . & 159 & 136 & .8 & 12 & .21 & 50 & 22 & 16 & .0 & 203 & 50 & 6.6 & 13 & 278 \\
\hline Illinois River, Peoria, Ill. & 43 & 26 & .8 & 12 & .21 & 49 & 21 & 17 & .0 & 198 & 48 & 7.8 & 13 & 271 \\
\hline $\begin{array}{l}\text { Illinois River, Kamps- } \\
\text { ville, lll.................... }\end{array}$ & 188 & 145 & .8 & 12 & .27 & 47 & 20 & 18 & .0 & 202 & 42 & 4.3 & 15 & 267 \\
\hline $\begin{array}{l}\text { Kaskaskia River, Shelby- } \\
\text { ville, Ill................. } \\
\text { Kaskaskia River, Car- }\end{array}$ & 110 & 84 & .9 & 16 & .23 & 53 & 26 & 13 & .0 & 262 & 34 & 6.9 & 5.6 & 279 \\
\hline $\begin{array}{l}\text { Kaskaskia River, Car- } \\
\text { lyle, Ill............................ } \\
\text { Mudy River, Murphys- }\end{array}$ & 184 & 126 & .7 & 17 & .39 & 47 & 20 & 14 & .0 & 213 & 34 & 4.8 & 6.9 & 248 \\
\hline $\begin{array}{l}\text { boro, Ill... } \\
\text { Mississippi River, Mo- }\end{array}$ & 245 & 129 & .5 & 24 & 2.1 & 25 & 12 & 20 & .0 & 72 & 72 & 2.0 & 13 & 225 \\
\hline $\begin{array}{l}\text { line, Ill } \\
\text { Mississippi }\end{array}$ & 117 & 106 & .9 & 16 & .39 & 33 & 13 & 10 & .0 & 152 & 24 & 1.8 & 3.7 & 179 \\
\hline $\begin{array}{l}\text { Quincy, Ill............ } \\
\text { Mississippi River, Ches- }\end{array}$ & 173 & 119 & .8 & 18 & .46 & 36 & 16 & 11 & .0 & 175 & 25 & 2.2 & 4.4 & 203 \\
\hline ter, llil . River of Wa- & 858 & 634 & .8 & 22 & .39 & 44 & 16 & 21 & .0 & 174 & 56 & 2.7 & 9.8 & 269 \\
\hline $\begin{array}{l}\text { Danville, Ill..... } \\
\text { rass River, }\end{array}$ & 115 & 82 & .8 & 14 & .29 & 54 & 25 & 13 & .0 & 243 & 42 & 12 & 4.5 & 281 \\
\hline $\begin{array}{l}\text { Embarrass R i ver, } \\
\text { Charleston, Ill.......... } \\
\text { Embarrass River, Iaw- }\end{array}$ & 155 & 140 & .9 & 17 & .34 & 51 & 24 & 13 & .0 & 249 & 31 & 7.6 & 4.9 & 270 \\
\hline $\begin{array}{l}\text { Embarrass River, Law- } \\
\text { renceville, Ill........... } \\
\text { Little Wabash River. }\end{array}$ & 118 & 66 & .7 & 17 & .53 & 44 & 19 & 28 & .0 & 195 & 35 & 3.7 & 35 & 283 \\
\hline 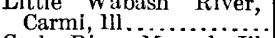 & 135 & 68 & .5 & 26 & 2.0 & 20 & 9. & 15 & .0 & 88 & 32 & & 7.5 & 176 \\
\hline Cache River, Mounds, Ill. & 134 & 66 & .6 & 22 & 2.5 & 19 & 6.0 & 15 & .0 & 85 & 19 & 2.1 & 6.8 & 149 \\
\hline
\end{tabular}





\section{INDEX.}

A.

Acknowledgments to those aiding

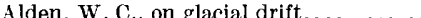

Alton, water supply of................. 41-42

Analyses, charts showing.............. 16,18

tables giving. . . . . . . . . . . . . . . . 62-89

Anderson, J. F., work of. . . . . . . . . . . . 52

Armold. C. H., work of ................. 50

\section{B.}

Barnhouse, Perry, work of...............

Barton, Alfred, work of...................

Bartow, Edward, work of.

Bicarbonates, data on.

determination of..

Bloomington, water supply of.

Boilers, water for water for, analyses of.

Brinkoetter, F. J., work of.

Brotherton, James, work of.

C.

Cache River, description of.

water $\mathrm{cf}$, analysis of

$53,88,89$

quality of . . . . . . . . . . . . . . . $52-53$

samples of.................... 52

softening of.................... 61

Cairo, water supply of ................. 53

Calcium, data on . . . . . . . . . . . . . . . . . 62-89 determination of ................... 16

Calvert, C. K., work of . ................ 8,17

Carbonates, data on . . . . . . . . . . . . . . . 62-89 determination of.................... 16

Carbondale, water supply of .............. 41

Carlyle, water at, analysis of ........ $39,48,79,89$ water supply of.................... $\quad 39$

Carmi, water at, analyses of . ........... 87, 89 water supply of.................... 51-52

Cartter, reservoir at, water from .......... 20,61 reservoir at, water from, analyses of...... 62,89

Champaign, water supply of............. $\quad 54$

Chandler ville, water at, analysis of . . . . . 32.74,89

Charleston, water at, analyses of........ 51,85, 89 water supply at................... 50

Chester, water at. ............ 42-43, 45-49, 83, 89 water at, analysis of . . . . . . . . . $42,45,48,83$

Chicago, water supply of.............. 18-19,54 water supply of, analyses of............ 19

Chicago drainage canal, description of....... 25 effects of............................ 37 water of, solids in $\ldots \ldots \ldots \ldots \ldots \ldots \ldots \ldots . . .25,37$
Page.

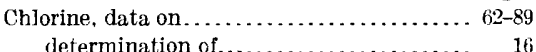

Cities, water consumption of ..............

Climate, character of..................... $9-10$

Coal, character and distribution of.......... 11

Coal-mine drainage, effect of, on water...... 12-13

Collins, W. D., work of ............ 7-8,16-17

Cooperation, board for control of......... $\quad 7-8$ plan of ....................... $7-8$

Culture, description of.................. 11-14

Cypress, water at....................... 61 water at, analyses of............... 64,89

\section{D.}

Danville, water at, analyses of........... 84,89 water supply of..................... 49

Davidson, Ira, work of . ................ 33

Decatur, water at, analysis of.......... $32,72,89$ water supply of.................... 31

Des Moines River, water of, quality of...... 43

Desplaines River, description of ........... $\quad 26$ municipal supplies from .............. $\quad 26$ water of, quality of .................. 26

Dissolved matter. See Solids, dissolved.

Distilleries. Sce Liquor business.

Drift, glacial, distribution of.............. 10 wells in......................... 11

Drinking, water used for ................ $5-6$

Dry residue, composition of.............. 17 composition of, chart showing........ 16

\section{E.}

East St. Louis, water supply of.......... 41-42 Economic features, description of.......... 11-14

Effingham, water supply of.............. 51

Elgin, water of, analysis of .......... 29-30, 69,89 water supply of.................... 28

Embarrass River, description of.......... $\quad 50$ municipal supplies................. 50 pollution of......................... 13,51 water of, analyses of . . . . . . . . 51,85-86, 89 quality of....................... $50-51$ samples of ...................... 50 softening of....................... 61

F.

Filtration, processes of................. $55-56$

Fox River, description of................ 28

discharge of....................... $\quad 29$ municipal supplies from.............. 28 powers on ......................... 28 
Page.

Fox River, water of, analyses of...... 29, 69-70,89 water of, quality of.............. 29-30,37 samples of...................... 29 softening of..................... 61

G.

Geology, description of. 10-11

Glacial drift, distribution of . . . . . . . . . . . 10 See alsn Drift.

Golconda, water supply of.

Greenup, water supply at.

Gregory, F. H., work of. .

\section{$\mathrm{H}$.}

Hydrography, description of............... See also particular streams.

\section{I.}

Illinois River, description of. discharge of .................... 34-36, 46 water of, analyses of .............. $75-77,89$ quality of . . . . . . . . . . . . . variation in............... $36-38$ samples of ..................... 33 softening of..................... 61 See also particular tributaries.

Illinois State Geological Survey, cooperation with.........................

Illinois State Water Survey, analyses by .... 7,16 cooperation with .................. 7

Indiana, oil-well pollution in.

Industries, character and distribution of.... 13-14 pollution from.................... 13-14 water used in.

essentials of $\ldots \ldots \ldots \ldots \ldots \ldots \ldots \ldots, 6,57-61$ Sce also Laundries; Boilers; Softening.

Iron, data on. determination of $62-89$

Iron industry, water demands of...........

\section{J.}

Joppa, reservoir at, water from 20,61 reservoir at, water from, analyses of . ... 65,89

\section{K.}

Kampsville, water at, analyses of..... 33, 48,77,89

Kankakee, water at, analyses of . . ........68, 89 water supply of .................. $\quad 27$

Kantakee River, description of........... 26-27 municipal supplies from............. 27 water of, analyses of $\ldots \ldots \ldots \ldots \ldots \ldots \ldots 68,89$ quality of ...................... 27,37 samples of ..................... 27 softening of..................... 61

Kaskaskia River, description of ........... 9,38 municipal supplies from ............. $\quad 39$ reclamation on .................... 38 water of, analyses of . .......... 39,78-79, 89 quality of . . . . . . . . . . . . . . . . . 39,48 samples of...................... 39 softening of..................... 61

\section{L.}

Lake Michigan, analyses of ...............

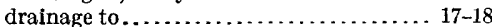
municipal supplies from .............. 18 water of, quality of
Lannigan, M. P., work of water at, analyses of dissolved solids in .................

Laundries, water for................ 6,57-58 Lawrenceville, water at, analyses of . . . . 5 51,86,89 Leighton, M. O., on Illino's rivers......... $6-7$ l.iquor industry, pollutior from........... 14 water for.....................

Litterer, Fred., work of .................

Little Wabash River, description of....... 51 municipal supplies of. .............. 51-52 water of, analysis of . . . . . . . . . . $53,87,89$ quality of....................... 52 samples of..................... 52 softening of...................... 61

Long, Bessie, work of. . . . . . . . . . . . .

M.

Madden, John, work of ................ 32

Magnesium, data on.................... 62-89 determination of. .................. 16 prevalence of, in surface water ........ 10,30

Manufactures, character and distribution of.. 13-14 See also Industries.

Map of Illinois, showing lccation of stations.. 14

Marion, reservoir at, water of . . . . . . . . 20,61 reservoir at, water of, analyses of. . . . . 63,89 sampling at......................... 15

Martin, J. W., work of . . . . . . . . . . . .

Meat industry, pollution " $^{\prime \prime m} \ldots \ldots \ldots \ldots \ldots$ 13-14

Mechanical filtration, methods of ......... 55-56

Metropolis, water supply of . ............ 53

Michigan, Lake. See Lake Michigan.

Mine drainage, effects of ............. 12-13,40

Minerals, contamination by .............. 6

Mines, character and distribution of . . . . . . . 12-13

Minnesota River, water of, quality of...... 44-45

Mississippi River, discharge of.......... 44,46 municipal supplies from . ............ 41-42 water of, analyses of . . . . . . . . . $81-83,89$ samples of..................... 42 softening of...................... 61

Missouri River, discharge of............. 46 water of, quality of ................. 43

Moline, sampling at.................... 15 water at.......................... 44 analysis of................... 42,81,89 water supply of. . ................ $41-42$

Morgan, Samuel, work of............... 52 Mounds, water at, analyses of . . . . . . . 53, 88,89 Muddy River, description of. . ........... 9,40 municipal supplies from.............. 41 water of, analysis of . . . . . . . . . . . 53, 80,89 quality of . . . . . . . . . . . $40,41,52-53$ samples of.................... 40 softening of..................... 61

Municipal supplies, need of. ............. 53 See also Wells; Surfaco supplies; particular cities.

Murphysboro, water at, analyses of...... 53, 80,89 N.

Nitrates, data on ..................... 62-89 determination of ................... 16 Nutt, Isaac, work of................... 39 
Obert, Gus, work of................. 32

Ohio River, municipal supplies from....... 53 water of, quality of ................ 53

Oil well drainage, effect of, on water...... 13,51 Olsen, Magnus, work of................ 42 Ottawa, water at, analysis of........ 29-30,70,89

Ozark uplift, description of...............

\section{P.}

Pennsylvanian series, character and distribution of.

Peoria, water at............... 33-38,76,89 water at, analyses of . . . . . . . . . . . 33,76 dissolved solids in ................ 36

Pollution, data on................... 7 prevalence of ....................... 5

Pontiac, water supply of ................. $\quad 30$

Population, data on .................. 11-12

Potassium, Sce Sodium and potassium.

Potsdam sandstone, character and distribu-

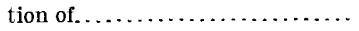
wells in ......................... 11

Precipitation. See Rainfall.

Purification, methods of.

practicability of.........

\section{Q.}

Quincy, water at. water at, analysis of. water supply of

\section{R.}

Rainfall, amount of ................... 9-10 Reservoirs, character and distribution of.... 19-20 water of, analyses of $\ldots \ldots \ldots \ldots \ldots \ldots \ldots .20$ quality of...................... 20

Rivers. See Streams; particular streams.

Rockford, water at, analyses of ..........66, 89 water at, dissolved solids in .......... 23-24 quality of ...................... 21-24 residue from.................... 22

Rock Island, water supply of ........... 41-42

Rock River, description of............. 9,20-21 discharge of ...................... 21,23 industries on ...................... 21 municipal supplies from............. 21 power on ......................... 21 water of, analyses of ............. $66-67,89$ quality of . . . . . . . . . . . . . . 22-24, 43 samples from .................. 21-22 softening of..................... 61

Ruegg, Mo., water at, quality of........ 48

\section{S.}

St. Peter sandstone, character and distribution of....................... wells in ......................... 11

Samples, analysis of, methods of. . . . . . . 15-17 analysis of, results of . . . . . . . . 17, $62-89$ collection of.

Sand filtration, use of.

municipal supplies from ............. 31-32

water of, analyses of ........... 32, 72-74, 89 quality of ...................... 32 samples of..................... 32 softening of. .................... 61
Schilling, George, work of .

39

Shelbyville, water at, analyses of .............. 39, 78,89 water supply of...................... 39

Silica, data on ........................ 62-89 determination of..................... 16

Sodium and potassium, data on .......... $62-89$ determination of..................... 16

Softening, processes of . . . . . . . . . . $56-57,59-61$ processes of, cost of . . . . . . . . . . . . . . 60-61

Solids, dissolved, data on............... 62-89 determination of..................... 16 relation of, to suspended matter, chart showing................... 18

Springfield, water at, analyses of ....... $32,73,89$ water supply of.................... 31

Stagner, H. C., work of ................. $\quad 40$ Steam boilers. See Boilers.

Steenberg, W. V., work of............... 49

Sterling, water at, analyses of . . . . . . . . . 67,89 water at, dissolved solids ir . . . . . . . . . 23-24 quality of . . . . . . . . . . . . . . . . $21-24$ residue from..................... 22

Straley, A. L., work of ................ $\quad 27$

Streams, descriptions of ................... 9

Streams, flow of ...................... 9 water of, quality of. See S irface waters. softening of.................... $60-61$

Streator, water at, analyses of . . . . . . . . 71,89 water supply of.................... 30

Strodbeck, Louis, work of................ 50

Sulphates, data on ................... $62-89$ determination of.................... 16

Surface waters, conclusion on ............ 61-62 purification of ................... 54-57 quality of $\ldots \ldots \ldots \ldots \ldots \ldots \ldots \ldots, 9,10,15-17$ analyses of . . . . . . . . . . . . . . . . $62-89$ charts showing ................... 16, 18 determination of............... 6,15-17 See also particular waters.

Suspended matter, data on .............. $62-89$ determination of..................... 15 relation of, to dissolved matter, chart showing.....................

\section{T.}

Tables, analytical, on surface waters. . . . . . 62-89

Temperature, records of ................ 10

Topography, outline of ................ 8

Turbidity, data on .................. 62-89

determination of .................... 15

removal of..................... $55-56$

U.

University of Illinois, cooperation with..... 7

Urbana, laboratory at ................... 15

\section{$\mathrm{V}$.}

Vandalia, water supply of.................

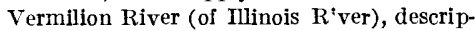
tion of..................... 30 municipal supplies from.............. 30 water from, analyses of . . . . . . . . . . . 71,89 quality of ...................... 31,37 samples of..................... 30 softening of..................... 61 
Vermilion River (of Wabash River), description of ..................... municipal supplies from................ water of, analyses of. quality of........ samples of. softening of..

W.

Wabash River, description of... See also particular tributaries.
Page. Page.

Wells, character and distribution of........ 53-54

municipal supplies from ............. 54

water of, character of ................ 54

determination of.................. 6

Winkleblack, James, work of . ........... $\quad 50$

Y.

Yohn, C. A., work of................... 22 
(1 空

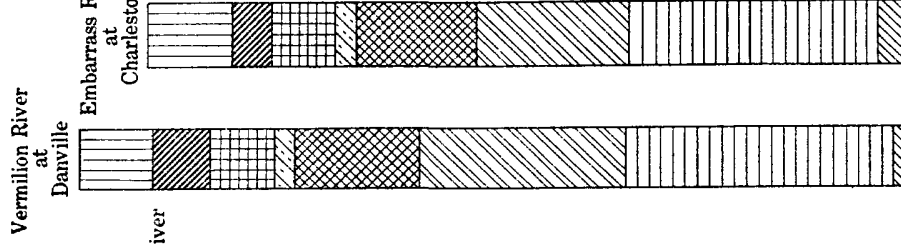

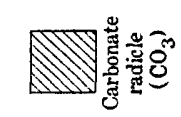
If

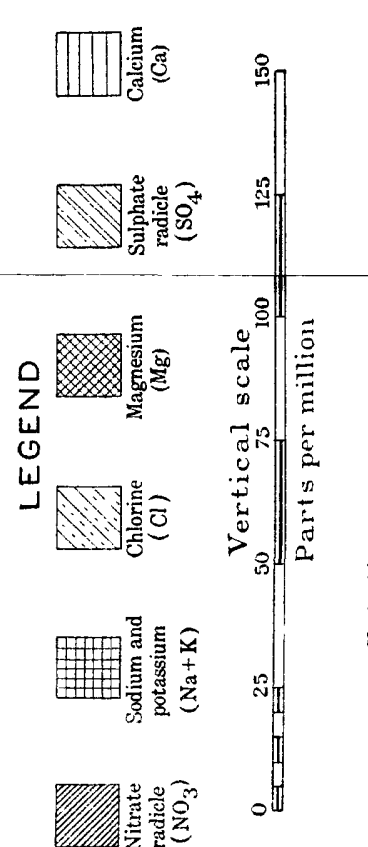

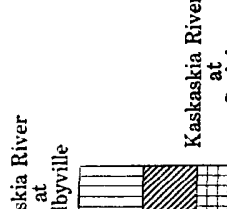

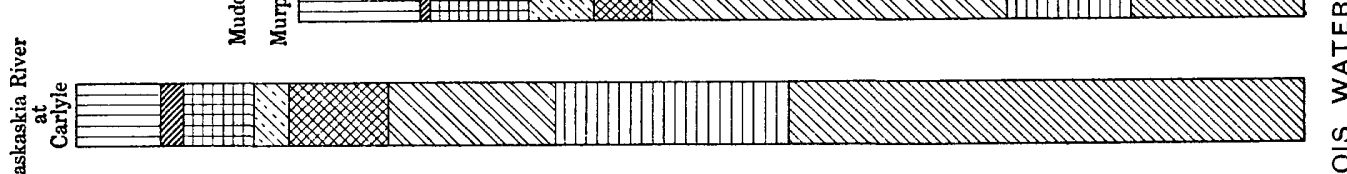

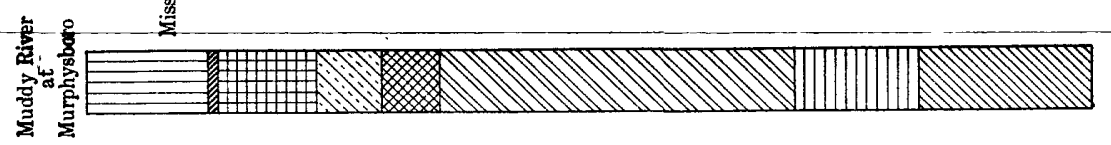
茫

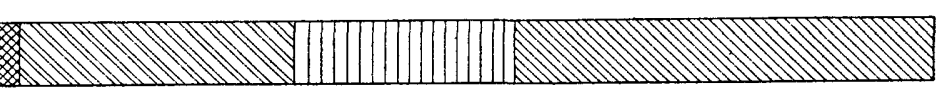

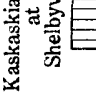


